\author{
UNIVERSIDADE DE SÃO PAULO \\ FACULDADE DE FILOSOFIA, LETRAS CIÊNCIAS HUMANAS \\ DEPARTAMENTO DE LETRAS MODERNAS \\ PROGRAMA DE PÓS-GRADUAÇÃO EM ESTUDOS LINGUISTICOS E \\ LITERÁRIOS EM INGLÊS
}

DANIELA MONTENEGRO DE SOUZA

O surgimento do comércio de romances ingleses nas lojas do Rio de Janeiro: dos requerimentos à Vossa Majestade aos armazéns de "commodo preço"

Versão corrigida

São Paulo

2014 
DANIELA MONTENEGRO DE SOUZA

O surgimento do comércio de romances ingleses nas lojas do Rio

de Janeiro: dos requerimentos à Vossa Majestade aos armazéns de "commodo preço"

Dissertação de Mestrado apresentada ao Departamento de Letras Modernas da Faculdade de Filosofia, Letras e Ciências Humanas da Universidade de São Paulo.

Orientadora: Profa. Dra. Sandra Guardini Teixeira Vasconcelos

São Paulo 
Para minha família 


\section{RESUMO}

Esta dissertação se propõe a analisar a trajetória dos romances ingleses no Rio de Janeiro nas três primeiras décadas do século XIX. Para tanto, utilizamos os documentos de requisição de liberação de livros da Mesa do Desembargo do Paço com a finalidade de apontar os responsáveis pela importação dessas obras literárias, bem como indicar quais romances ingleses tinham maior circulação. Visando esboçar o percurso dos romances, examinamos os anúncios de compra, venda, aluguel e leilão de dois periódicos importantes: a Gazeta do Rio de Janeiro (1808 - 1821) e o Diário do Rio de Janeiro (1821 - 1831).

Palavras-chave: Romance inglês, História da Literatura, História do Livro

\section{ABSTRACT}

The purpose of this dissertation is to analyse the circulation of English novels in Rio de Janeiro in the first three decades of the nineteenth century. The documents of the Mesa do Desembargo do Paço (the institution responsible for the censorship and liberation of books) in Rio de Janeiro will be used in order to bring light to the booksellers who were responsible for the importation of English novels as well as to highlight which of these novels were bestsellers. For an overview of the trade of English novels in Rio de Janeiro, the advertisements of two of the most important newspapers of the beginning of the nineteenth century will be taken into account: the Gazeta do Rio de Janeiro (1808 - 1821) and the Diário do Rio de Janeiro (1821 - 1831).

Keywords: English novels, History of Literature, Book History 
Registro o meu mais profundo agradecimento à minha orientadora, Sandra G. T. Vasconcelos, por ter me apresentado o universo da história da circulação de romances ingleses. Agradeço a paciência, a dedicação, os conselhos quase maternos e o incentivo acadêmico.

Ao professor Nelson Schapochnik, um agradecimento especial por ter acompanhado a minha pesquisa desde a iniciação científica. De baby Dani a candidata a mestre, espero ter respondido às expectativas. Obrigada pelo apoio, indicações de leitura e críticas construtivas.

Agradeço a professora Marisa Midore Deaecto por sua ajuda, conselhos, leitura crítica do meu relatório de qualificação e por dividir a sua paixão pela História do Livro.

Agradeço aos funcionários da Biblioteca Florestan Fernandes da FFLCH. Nunca esquecerei como Sandra Teixeira Alves entendia e comemorava comigo as pequenas descobertas que os microfilmes daqueles jornais velhos proporcionavam.

Os meus amigos também foram peças fundamentais para a conclusão deste trabalho. Em horas de desânimo, de dúvida e de cansaço, eles ofereceram ombros amigos. Às minhas seis amigas especiais, o meu eterno agradecimento. Com elas, sei que sempre conseguirei ir "para além e para o infinito".

À minha família, por sempre oferecer apoio incondicional em relação a todas as minhas escolhas. Meu pai, minha mãe e minha irmã sempre ofereceram um porto seguro e sempre acreditaram que a finalização e apresentação deste trabalho seriam possíveis. À família Pedroso Pimentel, por ter me aconselhado, me ajudado e me acolhido com tanto carinho em seu lar tão especial. À minha alma gêmea, Heraldo, o meu amor e minha gratidão por segurar a minha mão em momentos difíceis, acreditar em mim e me encher de ânimo.

Agradeço ao meu Pai espiritual, a força divina que iluminou as veredas que caminhei. 
SUMÁRIO

Introdução 8

Capítulo $1 \quad 20$

1.1 Um passeio pelo Rio de Janeiro de D. João à procura de romances ingleses $\quad 20$

1.1.1 O Rio de Janeiro e os estrangeiros $\quad 27$

1.2 Prosopografia dos requerentes de romances ingleses na Mesa do Desembargo do Paço 31

1.2.1 0 que se lia $\quad 53$

Capítulo 259

2.1 Romances ingleses no comércio fluminense 59

2.2 Periódicos 63

2.2.1 A Gazeta do Rio de Janeiro 66

2.2.2 O Diário do Rio de Janeiro $\quad 73$

2.3 ...aos armazéns de commodo preço 94

3. Considerações finais 114

Anexos 121

1. Mesa do Desembargo do Paço

2. Gazeta do Rio de Janeiro

3. Diário do Rio de Janeiro

Bibliografia $\quad 164$ 


\section{Introdução}

Os questionamentos que impulsionaram esta pesquisa surgiram ainda durante os estudos de Iniciação Científica que realizei entre 2003 e 2005, na Faculdade de Filosofia, Letras e Ciências Humanas da Universidade de São Paulo, que pretendiam elencar as obras de ficção inglesas que circularam no Rio de Janeiro entre 1821 e 1844 por meio da leitura dos anúncios do jornal Diário do Rio de Janeiro. Examinando os microfilmes desse periódico, pude perceber a repetida oferta de obras de prosa de ficção portuguesas, francesas, inglesas, alemãs e espanholas, bem como fazer um mapeamento inicial de alguns livreiros e negociantes de livros. Esta dissertação objetiva aumentar o alcance deste mapeamento inicial, ampliando o corpus e o período estudado, para isso foram utilizados os dados do periódico Gazeta do Rio de Janeiro (1808-1821). As análises do corpus fundamentaram as investigações sobre o comércio das obras de ficção inglesas com relação aos portos de onde eram importadas, bem como à maneira como elas chegavam às mãos dos leitores.

Ao tentar localizar informações sobre os anunciantes citados nos anúncios, pesquisei o ficheiro do Arquivo Nacional do Rio de Janeiro, seguindo as referências dos textos de Lúcia Maria Bastos P. das Neves e Tania Maria T. Bessone da Cruz Ferreira ${ }^{1}$, Márcia Abreu ${ }^{2}$, Maria Beatriz Nizza da Silva ${ }^{3}$ sobre a história do livro no Rio de Janeiro. Estas estudiosas exploraram a documentação da Alfândega com diferentes objetivos. Esta dissertação tem a preocupação de oferecer uma análise quantitativa dos dados encontrados e catalogados.

Os documentos de pedidos de liberação de livros da Mesa do Desembargo do Paço do Arquivo Nacional do Rio de Janeiro se encontram

\footnotetext{
${ }^{1}$ FERREIRA, Tania Maria T. Bessone da Cruz e NEVES, Lúcia Maria B. P. das . "Livreiros franceses no Rio de Janeiro. 1808-1823.", in História Hoje: balanço e perspectivas. IV Encontro Regional da Anpuh. Rio de Janeiro: Livraria Taurus-Timbre, 1990. p. 191-192.

${ }^{2}$ ABREU, Márcia. Os caminhos dos livros. São Paulo: FAPESP, 2003.

${ }^{3}$ SILVA, Maria Beatriz Nizza. A Gazeta do Rio de Janeiro (1808-1822) Cultura e Sociedade. Rio de Janeiro: EdUERJ, 2007.
} 
divididos por ordem alfabética em quatro caixas numeradas de 168 a 171 . A conservação desses documentos é também uma constante preocupação desta pesquisa, já que, durante o trabalho de digitalização do conteúdo das caixas em julho de 2010, um dos pacotes não foi encontrado pelas bibliotecárias responsáveis pelo acervo no Arquivo Nacional do Rio de Janeiro. Somente em uma segunda visita ao acervo do Arquivo Nacional - em janeiro de 2012 -, pude analisar esta caixa e fotografar seus documentos. Todos os dados foram organizados em tabelas anexas à dissertação, bem como cópias das imagens digitalizadas em um CD.

Interessa-nos delinear qual o caminho que os romances ingleses percorriam desde a sua chegada ao Rio de Janeiro até serem oferecidos em anúncios de jornais. Com este trabalho, objetivamos estabelecer resultados com relação a duas hipóteses: que os títulos de romances ingleses que aportavam na Alfândega seriam os mesmos anunciados nas lojas do Rio de Janeiro e que os responsáveis pela importação destes livros eram comerciantes na cidade. Estas duas hipóteses ajudariam a compreender e mensurar o comércio de romances ingleses no cenário oitocentista fluminense.

Para compreendermos melhor o circuito de romances ingleses no Rio de Janeiro oitocentista, é necessário refletir sobre como o comércio de livros foi alterado com a chegada da família Real e como as fontes historiográficas podem nos auxiliar a evidenciar estas mudanças.

\section{Os novos tempos no Brasil}

Nos primeiros anos do reinado de D. João VI, a instalação da família Real no Brasil transformou física e socialmente o Rio de Janeiro, com o intuito de recriar a vida da corte em território brasileiro. Assim, a cidade fluminense que hospedou a família real se modernizava e gradualmente se tornava um novo centro de poder, dependendo pouco de Lisboa. Além de empreendimentos como o Jardim Botânico, uma Escola de Medicina, uma Academia de Belas-Artes e um Museu de Arte, o novo governo trouxe sua "Bibliotheca Real" e os prelos da Tipografia Real que foi responsável pela impressão de periódicos, romances e anúncios de obras de prosa de ficção. 
Tais novidades no Rio de Janeiro podem ter auxiliado na propagação de romances estrangeiros a serem oferecidos ao público.

Houve também um crescimento do centro urbano, consequência do aumento do número de estrangeiros - entre eles negociantes, maquinistas ingleses, operários suecos, engenheiros alemães e artistas franceses ${ }^{4}-$, que se instalavam na cidade à procura de oportunidades e da nova clientela que ali se constituía. O comércio fluminense também se transformava e já oferecia artigos de luxo, alimentos, móveis e leitura de entretenimento importados da Europa. Comerciantes especializados em tecidos, roupas, móveis, "quinquilherias" e "bijouterias" importavam também livros ingleses de Portugal, França e Inglaterra.

Os comerciantes instalados no Rio de Janeiro ofereciam em anúncios de jornais as obras de ficção inglesas disponíveis em seus catálogos. Fontes de valor inestimável seriam esses catálogos que desapareceram no decorrer do tempo. Resta-nos reconstruir parte deles por meio de pistas deixadas por estes donos de lojas de papéis, armazéns ou livrarias por meio de anúncios.

Algumas das mudanças culturais no Rio de Janeiro do início do século oitocentista assinaladas acima foram registradas nos anúncios de comerciantes e particulares nos periódicos no início do século XIX. Antes mesmo da instalação da Imprensa Régia, os moradores do Rio de Janeiro já compravam as gazetas e livros no cais por marinheiros ingleses. ${ }^{5}$ Havia a necessidade da criação da imprensa sob a proteção oficial de $d$. João. A imprensa surge com a instalação dos prelos trazidos no porão da Medusa, por Antônio de Araújo, futuro conde da Barca. O primeiro jornal feito na imprensa oficial foi a Gazeta do Rio de Janeiro. O segundo jornal produzido no Brasil foi também em 1808, na antiga capital colonial, a Bahia: a Idade de Ouro do Brasil. A partir da primeira década do século XIX, outros jornais surgem no país, como: O Patriota (1813) e o Diário do Rio de Janeiro (1821) no Rio de Janeiro e A Abelha do Itacolomi (1824) em Minas Gerais. Dentre estes jornais, interessam-nos os

\footnotetext{
${ }^{4}$ Registro de Estrangeiros. 1808-1822 Rio de Janeiro: Arquivo Nacional:, Ministério da Justiça e Negócios Interiores, 1960.

${ }^{5}$ SODRÉ, Nelson Werneck. História da Imprensa no Brasil. Rio de Janeiro: Maad, 1999, p.14.
} 
anúncios da Gazeta do Rio de Janeiro e do Diário do Rio de Janeiro por serem pioneiros e pela grande quantidade de anúncios publicados.

A Gazeta do Rio de Janeiro foi o primeiro jornal institucional produzido pela Impressão Régia que circulou no Rio de Janeiro, tendo seu primeiro exemplar sido publicado em 10 de setembro de 1808. Este periódico visava enfrentar o crescente número de impressos importados clandestinamente - e que questionavam as idéias do absolutismo luso. Nelson Werneck Sodré comenta que a Corte precisava "dos louvores, de ver proclamar as suas virtudes, de difundir os seus benefícios, de, principalmente, combater as idéias que Ihe eram contrárias." ${ }^{6}$ Redigida por Manuel Ferreira de Araújo Guimarães, a Gazeta era composta de duas partes: a seção noticiosa e a de avisos. A primeira incluía artigos escolhidos de jornais europeus, cartas de políticos e militares e notícias sobre as famílias reais europeias. Já a segunda parte da Gazeta, era constituída de anúncios variados, mostrando o que era valorizado e digno de destaque na sociedade fluminense, fornecendo, assim, pistas que permitem reconstruir as possíveis preferências e alterações do gosto dos consumidores. Este periódico constituía "instrumento importante para o desenvolvimento das atividades comerciais"?

O segundo periódico escolhido foi o Diário do Rio de Janeiro, fundado e dirigido pelo português Zeferino Vito de Meireles. Conhecido por Diário do Vintém - por seu baixo preço - ou Diário da Manteiga - por publicar os preços da manteiga -, sua relevância pode ser explicada por diversos fatores: além de ser considerado o primeiro jornal informativo a circular no Brasil, nos oferece grande número de edições, tendo sido publicado de 1821 a 1878. A impressão do jornal ficava pronta geralmente às oito horas da noite e os interessados em anunciar deveriam deixar seus avisos em determinados estabelecimentos à tarde. Entre as notícias publicadas estavam furtos, assassinatos, notícias meteorológicas e movimento das marés. O Diário do Rio de Janeiro tem grande importância, pois foi nele que autores brasileiros como José de Alencar e

\footnotetext{
${ }^{6}$ Idem, p.29.

${ }^{7}$ CARDOSO, Teresa Maria Rolo Fachada Levy. A Gazeta do Rio de Janeiro: subsídios para a história da cidade (1808-1821). Dissertação de mestrado. Rio de Janeiro, Universidade Federal do Rio de Janeiro (UFRJ), 1988, p.63.
} 
Machado de Assis começaram a divulgar suas obras. Cinco Minutos, de José de Alencar, começou a ser publicado em 1856 - com o devido anúncio da venda do romance em 1858, ao passo que O guarani, do mesmo autor, foi editado no Diário do Rio de Janeiro em 1857. Machado de Assis escreveu ali seus primeiros textos jornalísticos e as crônicas "Comentários da Semana" a partir de 1861.

\section{História do Livro}

"It now look less like a field than a tropical rain forest" 8

Robert Darnton

Desde a década de 1980, estudiosos de diversas áreas desenvolvem pesquisas que têm como objeto a história do livro e da leitura no Brasil. A expressiva maioria desses trabalhos se baseia nos procedimentos metodológicos primeiramente propostos por Robert Darnton e Roger Chartier. Suas premissas nortearam esta pesquisa, notadamente a que toma o livro como fato social: ele é um artefato produzido e distribuído por uma rede de comércio.

Para Darnton, a história do livro surgiu da convergência de diversas disciplinas que lidam com os processo de comunicação. É uma disciplina relativamente nova cujo objetivo é refletir sobre como as ideias são transmitidas por meio da impressão e como a exposição ao material impresso tem afetado o pensamento e o comportamento da humanidade nos últimos cinco séculos. Os historiadores do livro se favorecem de estudos socioeconômicos e de estatísticas para melhor analisar a maneira como seus objetos de estudo aparecem e são difundidos na sociedade.

DARNTON, Robert. "What is the History of Books?" 1982 in http://dash.harvard.edu/handle/1/3403038. Ultimo acesso em Janeiro de 2014. 
Darnton, ainda, afirma que as condições de difusão do livro variam de acordo com a época e o local, porém, o livro impresso geralmente percorre o mesmo ciclo de vida que pode ser definido como circuito de comunicação.

O circuito de comunicação trilha o seguinte caminho:

autor $\rightarrow$ editor $\rightarrow$ impressor $\rightarrow$ transportador $\rightarrow$ vendedor $\rightarrow$ leitor

O leitor completa o ciclo porque influencia o autor antes e depois da composição da obra. Autores também são leitores, já que, por meio de suas leituras e associação com outros leitores, eles formam noções de estilo e gênero que afetam suas obras. $O$ autor pode responder às críticas a seus trabalhos anteriores ou antecipar reações que seu texto possa provocar. Deste modo, "the circuit runs full cycle":

However, they [book historians] define their subject, they will not draw out its full significance unless they relate it [book history] to all the elements that worked together as a circuit for transmitting texts ${ }^{9}$

A história do livro se preocupa com cada fase do circuito de transmissão de texto, bem como sua totalidade. Por ser uma tarefa tão grandiosa, os historiadores elegem fases deste para analisar. Porém, as partes estudadas só fazem sentido se forem relacionadas ao todo. Sobre os procedimentos metológicos no campo da historiografia do livro, o pensamento de Darnton vai ao encontro de Roger Chartier, que afirma a necessidade de integrar a mensuração dos dados referentes à história do livro com análises das materialidades precisas dos objetos culturais. ${ }^{10}$ De acordo com o pesquisador, cada vez mais, os historiadores de obras literárias têm consciência dos efeitos produzidos pelas formas materiais dos livros, já que as obras não possuem sentido estático e universal: "Elas são investidas de significações plurais e

\footnotetext{
${ }^{9}$ Ibidem, p. 75." do modo como eles definem seu objeto, eles não conseguirão alcançar sua totalidade a não ser que eles relacionem o seu objeto a todos os elementos que trabalham juntos no circuito de transmissão de textos" (Versão livre)

${ }^{10}$ CHARTIER, R. Roger Chartier interviewed by Robert Darnton. Transcrição do original e tradução: Dorothée de Bruchard, * apresentação e notas: Sandra Reimão. ${ }^{* *}$ Aulas inaugurais do Collège de France com o título "Écouter les morts avec les yeux" - Professeur Roger Chartier. http://www.matrizes.usp.br/index.php/matrizes/article/download/342/pdf. Ultimo acesso em Janeiro de 2014.
} 
móveis que se constroem no encontro de uma proposição com uma recepção“11. De acordo com Chartier:

"seja o que quer que façam, os autores não escrevem livros. Os livros não são absolutamente escritos. Eles são fabricados por copistas e outros artífices, por operários e outros técnicos, por prensas e outras máquinas."12

O autor afirma que não há texto sem materialidade, indicando assim a relevância daqueles que tomam decisões a respeito deste suporte: os editores e impressores.

A partir dos anos 1980, a historiografia do livro e as práticas de leitura no Brasil - especialmente ligadas ao período colonial - ganham maior atenção. Investigações baseadas nas listas de livros no circuito Portugal-Brasil e sobre a censura e a circulação de livros e de bibliotecas coloniais por meio de procedimentos de quantificação apurados revelam a crescente preocupação em traçar o perfil do leitor e o espaço ocupado pelo livro no Brasil oitocentista.

Laurence Hallewell nos oferece um dos estudos mais importantes e pioneiros acerca dos mercados editoriais e livreiros no Brasil em sua obra $O$ Livro no Brasil ${ }^{13}$. Sua pesquisa aborda não só o eixo Rio de Janeiro- São Paulo, como também apresenta dados sobre a circulação de livros em outros estados brasileiros, tendo como recorte temporal o início do comércio de livros no Brasil até as últimas décadas do século $X X$. Seus resultados serviram de base para o desenvolvimento desta dissertação, possibilitando um estudo prosopográfico dos agentes principais nos primórdios do comércio livreiro, no início do século XIX.

\footnotetext{
11 CHARTIER, R. A Ordem dos Livros: Leitores, autores e bibliotecas na Europa entre os séculos XIV e XVIII. Trad. de Maria Del Priore. Brasília: Editora Universidade de Brasília, 1999, p.17.

12 Ibidem.

${ }^{13}$ HALLEWELL, L. O Livro no Brasil: sua história, São Paulo: EdUSP. 2005.
} 
Outra obra que embasou esta pesquisa foi a recente História das Livrarias Cariocas $^{14}$, do jornalista Ubiratan Machado. Nela, os dados são expostos por meio de técnicas e de uma linguagem que remete diretamente às marcas textuais da reportagem. Suas informações focam a cidade do Rio de Janeiro e foram de suma importância para suscitar reflexões, nesta dissertação, acerca dos responsáveis pelas lojas de livros no Rio de Janeiro.

Precursores no estudo da circulação dos livros, como Lúcia B. P. das Neves ${ }^{15}$ e Leila Mezan Algranti ${ }^{16}$, oferecem pesquisas quantitativas sobre a circulação de livros, imprescindíveis para a realização deste trabalho, mostrando ser possível entender o universo dos livros do período joanino por meio da leitura dos manuscritos da Mesa do Desembargo do Paço. Neves utiliza os documentos da Alfândega para identificar os principais livreiros franceses estabelecidos no Rio de Janeiro. Em seu artigo de fundamental importância, a autora nos auxilia a encontrar as fontes sobre os intermediários do comércio livreiro no Rio de Janeiro.

Leila Mezan Algranti trabalha com a mesma documentação para desvendar o sistema de censura entre a segunda metade do século XVIII e as primeiras décadas do XIX desde o seu doutorado concluído em 1992. Sua pesquisa sobre os livros religiosos no Brasil colonial nos mostra os mecanismos e o funcionamento da censura, bem como o cotidiano nos claustros femininos da Colônia.

A pesquisa da historiadora de cultura Maria Beatriz Nizza da Silva a respeito do conteúdo da Gazeta do Rio de Janeiro auxiliou-me na análise e organização dos anúncios de livros ingleses no século XIX. Sua abordagem histórica transita em diversos territórios, inclusive o da política, e segundo a autora: "a história da cultura pode e deve utilizar métodos quantitativos sempre

\footnotetext{
${ }^{14}$ MACHADO, U. História das Livrarias Cariocas. São Paulo: EdUSP, 2012.

15 NEVES, L. M. B. ¿ Livreiros franceses no Rio de Janeiro: 1799 - 1824. In http://www.portcom.intercom.org.br/pdfs/bb3aea30006796253008218e5bdda0c1.pdf. Ultimo acesso: Janeiro de 2014.

${ }^{16}$ ALGRANTI, Leila Mezan. Livros de devoção, atos de censure: Ensaios de História do Livro e da Leitura na América Portuguesa (1750 - 1821). São Paulo: Hucitec, 2004.
} 
que estes sejam aplicáveis" ${ }^{17}$. Nizza da Silva examina com cuidado a Gazeta do Rio de Janeiro, destacando aspectos do cotidiano, das profissões, da cultura e do comércio fluminense no início do século $\mathrm{XIX}^{18}$. A autora vê a Gazeta como documento que, embora não forneça artigos de opinião e nem de literatura, é precioso como registro da vida cotidiana fluminense. Assim como Chartier e Darnton, ela encara o livro como uma mercadoria:

É vendido, comprado e colecionado; aprovado ou censurado; retido pela memória coletiva ou lançado no esquecimento; classificado segundo o sistema conceitual da época. ${ }^{19}$

Segundo M. B. Nizza da Silva, para estudar as relações entre o livro e a sociedade, é necessário refletir não só sobre o que é produzido pelos autores, mas também o que é consumido. ${ }^{20}$

Enfocando a inserção social da literatura, as pesquisadoras Marisa Lajolo e Regina Zilberman oferecem importantes estudos, apresentando uma perspectiva de investigação sobre as estratégias dos editores, impressores e escritores. Segundo as autoras ${ }^{21}$, o livro como objeto submetido à compra e venda é parte integrante dos mecanismos econômicos próprios do capitalismo e assume marcas da sociedade ao se transformar em propriedade privada. $\mathrm{O}$ livro faz parte deste sistema de compra e venda, e a presença ou ausência de seu comércio nos mostra traços do momento histórico da sociedade em questão. É nesse sentido que as autoras destacam a importância da forma como os livros estão inseridos no sistema de produção e recepção. A leitura de prosa de ficção faz parte de um complexo sistema cultural que acompanha a

\footnotetext{
${ }^{17}$ SILVA, M. B. N. Cultura e sociedade no Rio de Janeiro (1808 - 1822). São Paulo, SP: Com. Ed. Nacional, 1977, p. xxii

${ }^{18}$ SILVA, M. B. N. A Gazeta do Rio de Janeiro (1808-1822) Cultura e Sociedade. Rio de Janeiro: EdUERJ, 2007.

${ }^{19}$ Idem, p. 22.

${ }^{20}$ SILVA, M. B. N. Cultura e sociedade no Rio de Janeiro (1808 - 1822). São Paulo, SP: Com. Ed. Nacional, 1977, p. 170.

${ }^{21}$ LAJOLO, M. e ZILBERMAN, R. A Formação da Leitura no Brasil. São Paulo: Ática, 1996.
} 
modernização capitalista, exigindo "contextos e horizontes burgueses"22. Assim, o aparato cultural que viabiliza o consumo da leitura se articula com a situação sócio-histórica do leitor.

Márcia Abreu, por sua vez, examinou as listas de livros remetidos de Lisboa para o Rio de Janeiro pelos tribunais censórios entre 1768 e 1822, afirmando que as obras mais requisitadas foram: As aventuras de Telêmaco, de Fenelon; Selecta latini, de Pierre Chompré; História de Gil Blas de Santilhana, de Alain René Lesage; História do imperador Carlos Magno e dos doze pares da França, As mil e uma noites, em tradução de Antoine Galland; Obras poéticas de Bocage, Lances da ventura, acasos da desgraça e heroísmos da virtude, de D. Felix Moreno de Monroy e Ros; O feliz independente do mundo e da fortuna, do padre Teodoro de Almeida; Caroline de Lichtifield, de Isabelle de Montolieu e The complaints or night thoughts on life, death and immortality, de Edward Young. ${ }^{23}$

Luís Carlos Villalta ${ }^{24}$ sintetiza que o acesso às práticas de leitura e aos modos de apropriação pode ser estudado de diversas formas: em primeiro lugar, é possível acompanhar as estratégias editoriais; em segundo, estudar a circulação - compra, venda e empréstimos de livros que registrariam a movimentação e as inquietações do mercado livreiro. A terceira forma diz respeito aos modos de apropriação do livro pelo público leitor. Em quarto lugar, podem-se examinar as práticas de censura. Uma quinta maneira seria pesquisar as obras produzidas pelos homens de letras e, por fim, fazer inferências sobre as práticas de leitura a partir dos próprios elementos materiais e formais dos livros.

Nosso foco recai sobre o segundo item supracitado: associar as alterações na sociedade fluminense advindas da instalação da Corte à possível oscilação quantitativa na circulação de romances ingleses, e especular sobre

\footnotetext{
${ }^{22}$ LAJOLO, M. e ZILBERMAN, R. A leitura rarefeita: leitura e livro no Brasil. São Paulo: Ática, 2002, p. 10.

${ }^{23}$ ABREU, Márcia. O Caminho dos Livros. Campinas: Mercado de Letras, 2003.

${ }^{24}$ VILLALTA, Luís Carlos. "Reformismo ilustrado, Censura e Práticas de Leitura: usos do livro na América Portuguesa." Tese de Doutoramento. Departamento de História da Faculdade de Filosofia, Letras e Ciências Humanas da Universidade de São Paulo, 1999, p. 16.
} 
os agentes da importação, venda e circulação dessas obras, além de refletir sobre as manobras de divulgação utilizadas por eles para ter maior alcance.

Pretendemos ressaltar a importância de outras obras inglesas - os romances - que aportavam no Rio de Janeiro, bem como a variação no volume do seu comércio. Além disso, tencionamos relacionar os negociantes responsáveis por este comércio com os requerentes de obras da Alfândega, bem como assinalar a importância da propaganda nos periódicos, explorando os mecanismos de publicidade utilizados para aumentar as vendas de romances ingleses no Brasil.

Esta dissertação, que tem como objetivo estudar a circulação de romances ingleses entre 1808 e 1831 no Rio de Janeiro, visa apontar os importadores destas obras e quais os autores por eles escolhidos, bem como confirmar se estes livros eram também encontrados em lojas do comércio fluminense. O texto será dividido em duas partes principais: no primeiro capítulo, analisaremos os dados encontrados sobre os livros ingleses e seus requerentes nos documentos da Mesa do Desembargo do Paço.

Nosso objetivo principal do primeiro capítulo é apontar quem eram esses importadores e que obras procuravam trazer. Para tanto, dividimos o capítulo em quatro partes principais: a primeira relata o impacto da vinda da Corte e dos estrangeiros; a segunda comenta as instalações das novas instituições da vida intelectual; já a terceira mostra a prosopografia dos importadores de romances ingleses encontrados na Mesa do Desembargo do Paço ${ }^{25}$; a última parte traça um esboço de que obras foram mais citadas nos documentos examinados. Pretendemos pontuar qual a flutuação no volume dos romances ingleses que aportavam no Rio de Janeiro e qual o ano de maior importância para a importação destas obras. Interessa-nos também refletir sobre a escolha de quais romances comercializar feita por importadores, livreiros e comerciantes.

\footnotetext{
${ }^{25}$ Os documentos estão organizados alfabeticamente em quatro caixas e foram digitalizados no mês de julho de 2010. Todos os dados foram compilados em quatro planilhas que permitem a utilização de filtros que podem selecionar o tipo de informação a ser pesquisada. As planilhas desenvolvidas com todos os dados destes documentos encontram-se gravadas em um CD e anexadas à dissertação.
} 
No segundo capítulo, os anúncios de romances ingleses nos periódicos Gazeta do Rio de Janeiro e Diário do Rio de Janeiro ${ }^{26}$ serão avaliados com relação ao período de 1808 a 1831: da instalação da família real portuguesa no Rio de Janeiro ao fim do reinado de D. Pedro I. Interessa-nos destacar as obras anunciadas e as estratégias usadas pelos comerciantes anunciantes em um período de profundas transformações na vida dos habitantes do Rio de Janeiro. Na terceira parte do segundo capítulo, relacionamos os requerentes de romances ingleses citados nos documentos da Mesa do Desembargo do Paço aos comerciantes do Rio de Janeiro encontrados nos anúncios dos jornais Gazeta do Rio de Janeiro e Diário do Rio de Janeiro. Pretendemos assim demonstrar a oferta dessas obras inglesas para o público leitor no Rio de Janeiro e quem eram os agentes responsáveis pela importação destes bens. Utilizamos o mapa do Rio de Janeiro da terceira década oitocentista para organizar geograficamente a prosopografia dos comerciantes de livros.

${ }^{26}$ Os anúncios transcritos destes periódicos também estão gravados no $C D$ entregue juntamente com a dissertação. 


\section{Capítulo 1}

\subsection{Um passeio pelo Rio de Janeiro de $\mathrm{D}$. João à procura de romances ingleses}

Na manhã do dia 5 de março de 1808, após os vários dias de preparação, os habitantes do Rio de Janeiro acordaram aguardando as mudanças que chegariam pelo mar. Foi um impacto para os que desembarcavam e os que os recebiam. Houve festa, protocolo, sentimentos religiosos e de vassalagem e a novidade maior: a Corte. O cortejo foi protocolar, contou com desfiles e música. Foram nove noites de festas que "tiraram a cidade de sua modorra colonial" 27.

O conde de Arcos e vice-rei do Brasil, D. Marcos de Noronha, foi um dos responsáveis pelos preparativos para a recepção e instalação da Corte. Entre suas iniciativas estavam a supervisão de reformas para transformar um quartelgeneral em palácio real, as procissões e missas de boas-vindas e encomendas de "carne bovina, suína, avícola, bem como de aipim, batata-doce e frutas tropicais" ${ }^{28}$. A pomposa festa de recepção da Corte em 1808 incluiu salva de tiros, bandeiras hasteadas, execução de fogos de artifício e ruas decoradas com adornos de flores, folhas e cravos $^{29}$.

Os reinóis e os habitantes do Rio de Janeiro se desconheciam; Maurício Monteiro diz que:

${ }^{27}$ MONTEIRO, Maurício. A Construção do Gosto: Música e sociedade na Corte do Rio de Janeiro - 1808 - 1821. São Paulo: Ateliê Editorial, 2008, pág. 112.

${ }^{28}$ WILKEN, Patrick. Império à deriva: A Corte portuguesa no Rio de Janeiro, 1808-1821. Tradução de Vera Ribeiro. Rio de Janeiro: Objetiva, 2005, pág.103.

${ }^{29}$ OLIVEIRA. Anelise Martinelli Borges. "D. João VI no Rio de Janeiro: preparando um novo cenário". In: História em reflexão: revista eletrônica de História:

http://www.historiaemreflexao.ufgd.edu.br/A18/D.\%20JOAO\%20VI\%20NO\%20RIO\%20DE\%20 JANEIRO\%20preparando\%20o\%20novo\%20cenario.pdf?PHPSESSID=4cce677f287b7e 7bf2a5 0b81c45bcd01. Último acesso em dezembro de 2009. 
se, para os habitantes do Rio de Janeiro, a procissão real, a rainha e seu príncipe exibiram modos diferentes, para a Corte, era preciso, no mínimo, transformar o comportamento colonial para suportar o exílio. Além disso, era importante reconstruir o cenário do Rio de Janeiro para torná-lo um espaço possível de se viver". ${ }^{30}$

A instalação da família real mudou os hábitos e costumes dos habitantes do Rio de Janeiro, criando necessidades e proporcionando desenvolvimento urbano. A mudança da família real para o Brasil fez com que os ritmos e fluxos de funcionamento da Corte se sobrepusessem aos da cidade colonial, transformando-a socialmente e alterando sua arquitetura, bem como sua infraestrutura ${ }^{31}$. A adequação física à instalação da Corte incluiu desalojamentos da população local devido ao aumento do número de habitantes em cerca de 10 mil pessoas, impactando na vida política, cultural e, em especial, no comércio da cidade.

Maria Odila Silva Dias ${ }^{32}$ define como fundamentais no processo de enraizamento da metrópole na colônia alguns fatores, como a organização do comércio de abastecimento no Rio de Janeiro e os grandes investimentos em obras públicas. A autora cita os depoimentos do bibliotecário responsável pela Biblioteca Real, Luís Joaquim Santos Marrocos, que aponta os crescentes investimentos locais, como as reformas do arsenal da marinha, as ampliações realizadas no palácio de São Cristóvão, do palácio de Santa Cruz, das criações de loterias.

No âmbito da infraestrutura urbana, novas estradas foram abertas para facilitar a comunicação e o escoamento de produtos entre as cidades. O núcleo

\footnotetext{
${ }^{30}$ MONTEIRO, Maurício. "O fim da festa. Música, gosto e sociedade no tempo de D. João VI" in JANCSON, István e KANTOR, Iris (orgs.). Festa: Cultura \& Sociabilidade na América Portuguesa, volume II. São Paulo: Hucitec: Editora da Universidade de São Paulo : Fapesp : Imprensa Oficial, 2001. p. 570.
}

31 SLEMIAN, Andréa. Vida política em tempo de crise: Rio de Janeiro (1808 - 1824). São Paulo: Hucitec, 2006.

32 DIAS, Maria Odila Silva. A interiorização da metrópole e outros estudos. São Paulo: Alameda, 2005. 
urbano se expandiu, como se pode observar no mapa da cidade de $\mathrm{S}$. Sebastião do Rio de Janeiro, com suas ruas e vielas.

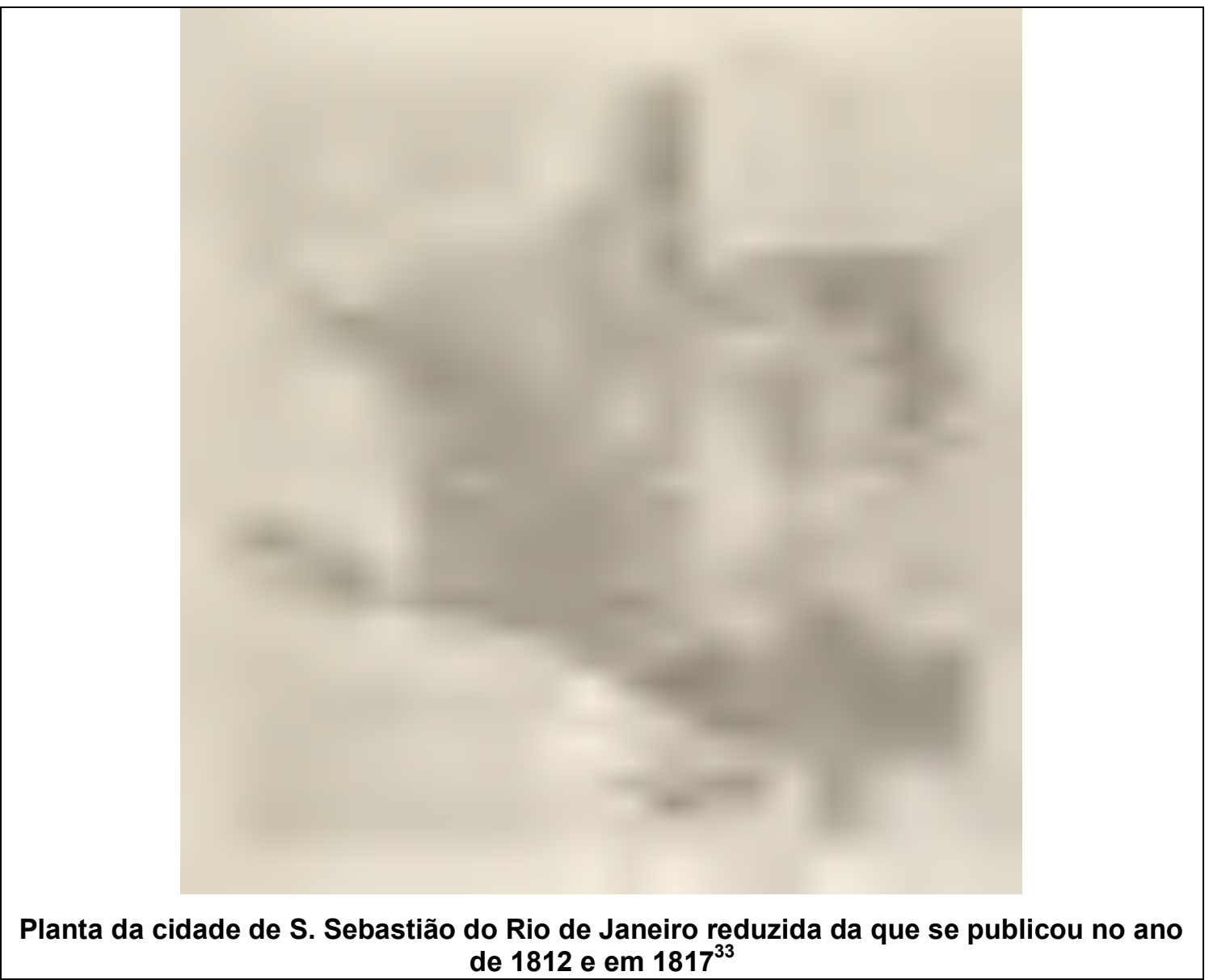

A instituição responsável pela instalação da Corte Real e pelo melhoramento e vigilância da cidade era chamada de Intendência Geral de Polícia. Segundo Kirsten Schultz ${ }^{34}$, a Intendência não poupava esforços para a construção de uma "cidade ideal" e trabalhava para garantir a melhoria das condições de vida. A Corte se incomodava com o calor excessivo e com os insetos, além de sofrer com os problemas de abastecimento de água e

${ }^{33}$ Planta da cidade de S. Sebastião do Rio de Janeiro reduzida da que se publicou no ano de 1812 e em 1817 [Material cartográfico]. Disponível em: http://purl.pt/897. Ultimo acesso em: 12 de junho de 2012.

${ }^{34}$ SCHULTZ, Kirsten. Versalhes tropical: império, monarquia e a Corte real portuguesa no Rio de Janeiro, 1808-1821. Rio de Janeiro: Civilização Brasileira, 2008, p. 156. 
inundações. Com o crescimento da cidade, obras como canalizações e inaugurações de fontes tentaram controlar a deficiência de abastecimento.

Neste sentido, planejamentos de construção de calçadas, iluminação de ruas, novas fontes, aterros sanitários foram iniciados. A ideia era projetar uma imagem de ordem e progresso por meio de instituições "identificadas com a cultura particular da monarquia de Lisboa" ${ }^{35}$. Exemplos dessas instituições foram a Capela Real e o Theatro Real. A Igreja de Nossa Senhora do Rosário foi elevada a Capela Real por um Alvará Real em junho de 1808. Já o Real Theatro de São João, inaugurado em 12 de outubro de 1813, aniversário de D. Pedro, pode ser considerado um marco da história da arte dramática no Brasil, pois apresentava para a Corte um repertório diverso, comédias e dramas.

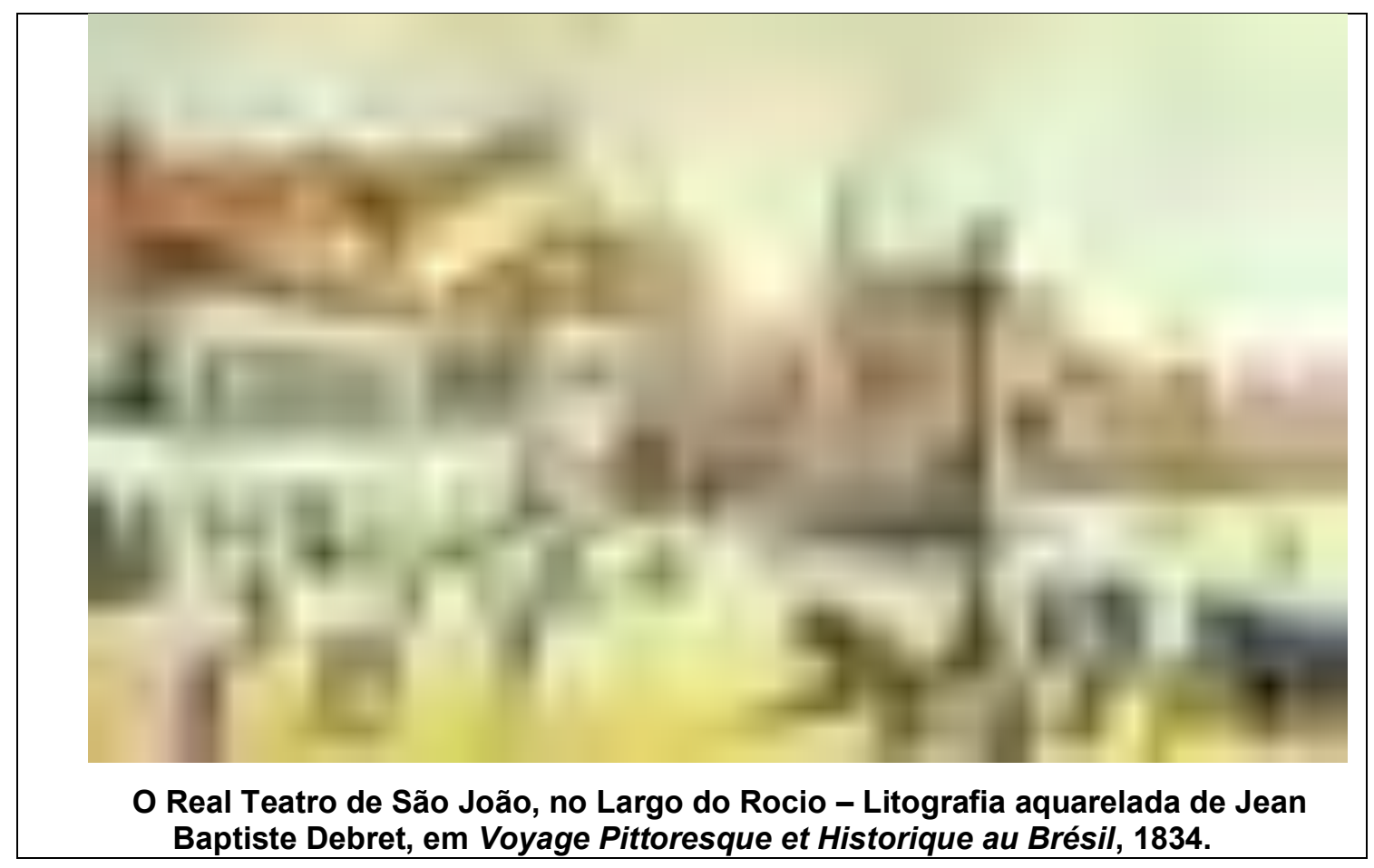

Além de empreendimentos como o Jardim Botânico, uma Escola de Medicina, uma Academia de Belas-Artes, um Museu de Arte, o novo governo trouxe a sua "Bibliotheca Real". Lilia Moritz Schwarcz ${ }^{36}$ escreve que, com um conjunto de 70 mil volumes, a Real Biblioteca era o símbolo do saber

\footnotetext{
${ }^{35}$ Idem.
}

${ }^{36}$ SCHWARCZ, Lilia Moritz. A Longa Viagem da Biblioteca dos Reis: do terremoto de Lisboa à Independência do Brasil. São Paulo: Cia das Letras, 2002, respectivamente pp. 277 e 395. 
acumulado: obras raras, documentos selecionados, códices, incunábulos, gravuras, partituras e mapas. Remontava aos primórdios da monarquia portuguesa desde D. João II (1477-1495), que reunira os livros dos primeiros monarcas da dinastia de Avis. Mas foi no reinado de D. João V (1706-1750) que o acervo adquiriu proporções grandiosas:

livreiros estrangeiros, agentes diplomáticos, acadêmicos de renome... todos pareciam envolvidos no mesmo objetivo de satisfazer as necessidades reais (...). Compravam-se bibliotecas inteiras no estrangeiro, coleções particulares e verdadeiras preciosidades, que eram recebidas tal qual troféus. ${ }^{37}$

A Bibliotheca Real chegou a ser considerada uma das maiores bibliotecas da Europa, pela quantidade e qualidade dos livros, "das mais preciosas que se conheciam no continente, composta de muitos milhares de volumes, que abrangiam vastos domínios do saber." 38

Motivo de orgulho por sua grandiosidade, a Real Biblioteca foi exaltada pelo padre Perereca em 1814 como "inapreciável tesouro", meio eficaz "para o progresso da literatura, aumento das artes e difusão das ciências." 39 O artista francês Étienne Victor Arago, após visitá-la, registrou a existência de um acervo com cerca de 70 mil volumes bem escolhidos ${ }^{40}$.

Parte também deste processo de instalação de instituições e ferramentas para o funcionamento da burocracia da Corte, a Tipografia Real foi peça fundamental no engendramento da cultura letrada. Trazidos na nau

${ }^{37}$ Idem, p. 32.

${ }^{38}$ Idem, p. 73.

${ }^{39}$ LESSA, C. R. "As bibliotecas brasileiras dos tempos coloniais: apontamentos para um estudo histórico" in: Revista do Instituto Histórico e Geográfico Brasileiro, vol. 191, 1946, p. 277.

40 SCHWARCZ, Lilia Moritz. "D. João VI e os livros no Brasil: o caso da Real Biblioteca" in: http://www.realgabinete.com.br/coloquio/3_coloquio_outubro/paginas/14.htm\#_ftnref29 Acesso: 10 de dezembro de 2009 
Meduza, os prelos da tipografia comprada por D. Antonio Araújo de Azevedo prestariam seus serviços à Secretaria do Estado dos Negócios Estrangeiros e da Guerra. Inicialmente destinada às necessidades burocráticas do governo e instalada em uma casa na Rua do Passeio, a Tipografia teve como novo responsável D. Rodrigo de Souza.

Conforme o Decreto sacramentado pelo Príncipe Regente:

Tendo-Me constado que os Prélos, que se achão nesta Capital, erão os destinados para a Secretaria de Estados Estrangeiros; da Guerra; e Attendendo á necessidade que ha de Officina de Impressão nestes Meus Estados: Sou Servido, que a Caza, onde eles se estabelecerão, sirva interinamente de Impressão Regia, onde se imprimirão exclusivamente toda a Legislação, e Papeis Diplomaticos, que emanarem de qualquer Repartição do Meu Real Serviço; e se possão imprimir toda, e quaesquer outras Obras; ficando interinamente o seu governo, e administração à mesma secretaria. $^{41}$

A Impressão Régia foi instituída no Rio de Janeiro com total monopólio do governo, tendo uma sucessão de diferentes nomes: Impressão Nacional, Tipografia Real, Tipografia Régia, Régia Tipografia e Imprensa Nacional. Segundo Simone Cristina Mendonça Souza ${ }^{42}$, em menos de duas décadas de funcionamento, essa casa impressora foi responsável pela publicação de títulos de diferentes almanaques, calendários e livros para as disciplinas lecionadas na Real Academia dos GuardasMarinha, na Escola Anatômica Cirúrgica e Médica do Rio de Janeiro, na Academia de Artilharia e Fortificações e na Real Academia Militar.

A Impressão Régia foi responsável pela publicação do primeiro periódico impresso no Brasil: a Gazeta do Rio de Janeiro, que circulou entre 1808 e 1822. Antes dessa publicação, a impressão do jornal enviado ao Brasil chamado Correio Brasiliense funcionava em Londres. Hipólito José da Costa,

\footnotetext{
${ }^{41}$ Reprodução do fac-similar do Decreto de 13 de maio de 1808 in BERGER, Paulo. A Tipografia no Rio de Janeiro: impressores bibliográficos 1808 - 1900. Rio de Janeiro: Cia. Industrial de Papel Pirahy, 1984, p. VIII.
}

42 SOUZA, Simone Cristina Mendonça. Primeiras impressões: romances publicados pela Impressão Régia do Rio de Janeiro (1808-1822). Tese de doutorado, Instituto de Estudos da Linguagem, da Universidade Estadual de Campinas, 2007. 
brasileiro casado com uma inglesa, havia lançado em junho de 1808 o Correio Brasiliense. Esse jornal de forte influência inglesa teve seu primeiro número três meses antes de sair a Gazeta do Rio de Janeiro. No quinto número do Correio Brasiliense, Hipólito da Costa anunciava o estabelecimento no Rio de Janeiro da Impressão Régia.

Saiba o mundo, e a posteridade que, no ano de 1808 da era cristã, mandou o governo português, no Brasil, buscar à Inglaterra uma impressão, com os seus apendículos necessários, e a remessa que daqui se lhe fez importou em cem libras esterlinas!!! Contudo diz-se que aumentará esse estabelecimento, tanto mais necessário quanto o governo ali nem pode imprimir as suas ordens para Ihes dar suficiente publicidade. Tarde, desgraçadamente tarde: mas, enfim, aparecem tipos no Brasil: e eu de todo o coração dou os meus parabéns aos meus compatriotas brasilienses ${ }^{43}$.

Em 1821, montaram-se duas tipografias no Rio de Janeiro e, em 1822, mais quatro. Nesse mesmo ano, em uma delas, nasceu o Diário do Rio de Janeiro. Fundado pelo português Zeferino Vito de Meireles, o Diário mantinhase distante das notícias políticas, publicando avisos meteorológicos, notícias particulares e anúncios diversos.

Nos anúncios do Diário do Rio de Janeiro e Gazeta do Rio de Janeiro, observamos grande número de anúncios de diversos produtos estrangeiros, publicados pelos recém-instalados europeus.

${ }^{43}$ RIZZINI, Carlos. O Livro, o Jornal e a Tipografia no Brasil (1500 - 1822). São Paulo: Imprensa Oficial do Estado, 1988, p. 315. 


\subsubsection{O Rio de Janeiro e os estrangeiros}

O Brasil aparentava ser uma terra de oportunidades. Segundo Armelle Enders, a presença da Corte atraiu ondas de imigrantes: soldados portugueses a serviço do regente, súditos do rei da Espanha fugindo dos vice-reinados vizinhos ao Brasil e comerciantes ingleses ${ }^{44}$. Estes últimos encararam a abertura dos portos brasileiros em 1808 como uma excelente chance de expandir seu comércio, aproveitando ao máximo a política que Portugal vinha colocando em prática ${ }^{45}$.

Assim como os ingleses e os portugueses, outros europeus vieram para o Brasil em busca das prometidas oportunidades. Essa imigração foi decisiva em âmbito nacional, pois nesse grupo encontravam-se mecânicos, banqueiros, negociantes, médicos, técnicos, engenheiros e outros profissionais. Tais profissionais foram responsáveis pelo funcionamento das novas instituições trazidas com a vinda da corte. A população do Rio de Janeiro cresceu com pessoas à procura de trabalho: portugueses, alemães, irlandeses, espanhóis, italianos e norte-americanos ${ }^{46}$. Os imigrantes que chegaram nas primeiras décadas do século XIX necessitavam informar a Alfândega do porto do Rio de Janeiro sobre todos os livros que traziam consigo.

O Registro de Estrangeiros nos fornece uma listagem daqueles que chegavam ou partiam do porto. José Honório Rodrigues aponta a renovação populacional com grande quantidade de imigrantes provenientes da Europa. Nas duas primeiras décadas do século XIX, de 4234 pessoas, a maioria era espanhóis, seguidos em quantidade por franceses e ingleses ${ }^{47}$. Já nas décadas seguintes, o volume de

${ }^{44}$ ENDERS, Armelle. A História do Rio de Janeiro; tradução de Joana Angélica d'Ávila Melo. Rio de Janeiro: Gryphus, 2008, p. 18.

${ }^{45}$ SOUSA, Octávio Tarqüínio de. "O livro de um mestre" prefácio à $1^{\text {a }}$ edição de Ingleses no Brasil de Gilberto Freyre. Rio de Janeiro: Topbooks Editora, 2000, p. 19.

${ }^{46}$ WILCKEN, Patrick. Império à deriva: a Corte portuguesa no Rio de Janeiro 1808 - 1821. trad. Vera Ribeiro. Rio de Janeiro: Objetiva, 2005.p. 198.

\footnotetext{
47 "do total registrado entre 1808 e 1822, 4232 pessoas, sem contar muitas vezes os familiares, esposa, filhos, criados, mais de 1500 são espanhóis, quase 1000 franceses, mais de 600 ingleses, mais de 200 alemães, quase duas centenas de italianos, quase 100 suíços e norteamericanos, quase 50 suecos, 30 holandeses, 25 irlandese, 13 austríacos e 11 dinamarqueses e escoceses" in Registro de Estrangeiros (1808 - 1822), nota de José Honório Rodrigues, Ministério da Justiçã e Negócios Interiores, Arquivo Nacional, Rio de Janeiro, 1960, p. 6.
} 
franceses e ingleses aportando no Rio de Janeiro é consideravelmente maior do que o das outras nacionalidades a partir de 1826. De acordo com os dados do Arquivo Nacional, o número de ingleses registrados é superior ao número de franceses até 1826. Entretanto, após este ano, o número de franceses supera o de ingleses ${ }^{48}$.

Os dados do Registro citam as ocupações dos estrangeiros que aportavam no Rio de Janeiro. Infelizmente, não somos informados sobre o tipo de mercadorias comercializadas por cada estrangeiro negociante. Entretanto, há ocorrência de "livreiros" e "impressores", sugerindo, assim, como a relevância dessas profissões na Europa é transportada para este lado do oceano. O Registro nos noticia casos como o do livreiro Luiz Alberto Gouph Cogez que partiu para a França em julho de 1825, ou dos impressores franceses Elzear Fabre e Gerard que também passaram pelo Rio de Janeiro nos anos de 1824 e 1827.

Assim como o controle exercido pela Metrópole sobre a entrada de estrangeiros no Rio de Janeiro, havia a restrição sobre a vida intelectual e veículos de cultura. O Príncipe Regente se preocupava com as idéias estrangeiras iluministas que aportavam por meio dos livros trazidos pelos imigrantes. A tentativa de vigilância das ideias na colônia não se restringia à censura de obras: para que tal vigilância ocorresse, as tipografias eram proibidas antes de 1808 e as obras a ser impressas na Impressão Régia necessitavam de autorização de Sua Majestade, e até mesmo as Academias Científicas existentes nas últimas décadas do século XVIII foram banidas. Essas medidas visavam manter a estabilidade da Corte Real na América Portuguesa. Como pontuou Marcelo Ipanema ${ }^{49}$, o processo de implantação da censura no Brasil teve três momentos distintos. Em primeiro lugar, a nomeação dos censores, seguida do estabelecimento da função censora do Desembargo do Paço e, finalmente, a colaboração da Intendência da Polícia do Rio de Janeiro.

O decreto de 27 de setembro de 1808, assinado por D. João, oficializava o Desembargo do Paço como o organismo censor no Brasil. A nova conjuntura política forçava a criação de um aparato burocrático. Villalta comenta que o funcionamento da

\footnotetext{
${ }^{48}$ Registro dos Estrangeiros: 1823 -1830 é uma publicação de 1961 do Ministério da Justiça e Negócios Interiores do Arquivo Nacional do Rio de Janeiro.

49 IPANEMA, Marcello \& Cibelle. "Subsídios para a História das Livrarias" in Revista do Livro, Rio de Janeiro, 1968, n. 32, ano XI, pp. 23 - 31.
} 
Mesa do Desembargo do Paço no Rio de Janeiro exigiu a nomeação de novos censores, criação de leis e publicação de alvarás ${ }^{50}$.

Os títulos submetidos ao crivo dos censores eram variados. Algranti descreve as etapas dos procedimentos de censura possíveis de se verificar a partir da leitura das licenças para liberação de livros:

é que grandes e pequenos volumes contendo livros ficavam retidos na alfândega à espera das licenças necessárias. O interessado procedia, então, a um inventário dos livros que desejava liberar encaminhando essas listagens à Mesa do Desembargo do Paço. O escrivão da Câmara, por sua vez, enviava as listagens aos censores régios (leigos ou religiosos) que emitiam seus pareceres. Se favoráveis, as obras eram liberadas. Quanto àquelas sabidamente proibidas ou as simplesmente suspeitas, negavamse as licenças. ${ }^{51}$

Uma provisão de 14 de outubro de 1808 proibiria os Juízes de Alfândega de despachar livros se não tivessem a "devida licença" do Desembargador do Paço. Num edital de 30 de maio de 1809, o Intendente de Polícia, Paulo Fernandes, proibiu a publicação de anúncios, avisos e notícias antes que os livros fossem vistos, examinados e detalhadamente aprovados, sob a pena de prisão e multa. Neves ${ }^{52}$ argumenta que a preocupação primordial dos censores do início do século XIX estava relacionada a dois fatores: o temor em relação às novas ideias políticas propagadas pelos franceses e a preocupação com a moral e com a religião.

Vale ressaltar que as documentações dos órgãos censores auxiliam, nos dias de hoje, na catalogação das obras que circulavam no Brasil no início do século XIX.

50 VILLALTA, Luiz Carlos. "A censura, a circulação e a posse de romances na América Portuguesa (1722 - 1822)" in: ABREU, M. e SCHAPOCHNIK, Nelson. Cultura Letrada no Brasil. Campinas: Mercado de Letras, Associação de Leitura ndo Brasil; São Paulo: Fapesp, 2005.

${ }^{51}$ ALGRANTI, L. M. "Política, religião e moralidade: a censura de livros no Brasil de D. João VI (1808 - 1821)" in Carneiro, Maria Luiza Tucci. (org.) Minorias Silenciadas: Historia da Censura no Brasil. São Paulo: EdUSP, s/d.

52 NEVES, Lúcia Maria Bastos P. "Antídotos contra obras ímpias e sediciosas: censura e repressão no Brasil de 1808 a 1824" in: ABREU, M. Leitura, história e história da leitura. Campinas: Mercado de Letras, 2002, pp. 377-394. 
Por meio dos pedidos de autorização para o envio de material impresso para o Brasil, estudos como o de Márcia Abreu ${ }^{53}$ comprovam a existência de um público leitor na cidade do Rio de Janeiro.

Infelizmente, a conservação dos requerimentos de liberação de livros e das respostas dos censores da Mesa do Desembargo do Paço é precária e percebemos a falta de muitos documentos. ${ }^{54}$

A leitura desses documentos nos remete à questão da circulação de livros e nos revela alguns nomes de requerentes importantes. A partir de prosopografias ${ }^{55}$ que examinam as atividades dos requerentes de liberação de livros, procuro investigar quais os desempenhos destes indivíduos dentro da Corte e o alcance geográfico dos romances ingleses na sociedade fluminense no início do século XIX.

${ }^{53}$ ABREU, Márcia. Os Caminhos dos Livros. Campinas: Mercado de Letras, 2003.

${ }^{54}$ As imagens digitalizadas dos documentos encontrados nas caixas 168, 169, 170 e 171 do Desembargo do Paço do Arquivo Nacional do Rio de Janeiro podem ser visualizadas no CD que acompanha a dissertação.

${ }^{55}$ Abordagem prosopográfica é definida nas palavras de Sabine Juratic como "constituição de biografias individuais submetidas a uma grade comum". Ver: Juratic, Sabine. Da prosopografia dos livreiros ao estudo das redes do livro. Balanço e perspectivas da pesquisa. Livro. Revista do Núcleo de Estudos do Livro e da Edição. N. 1, maio 2011. São Paulo: USP/Ateliê Editorial, p. 75. Esta abordagem se aproxima da de autores anglo-saxônicos, como Peter Burke e Jean e Roderick Barnam. 


\subsection{Prosopografia dos requerentes de romances ingleses na Mesa do Desembargo do Paço}

Neste trabalho, procurei selecionar os dados referentes somente aos romances ingleses constantes nas listas de pedidos de liberação de livros. Minha proposta é ressaltar a importância das obras inglesas, mesmo que elas tenham sido consideradas tímidas e inferiores à presença portuguesa e francesa ${ }^{56}$. Ao tentar integrar as relações entre os diferentes homens e até mesmo mulheres, nesta sociedade patriarcal, que pediam a liberação de romances ingleses a estas obras, espera-se compreender e destacar o alcance de autores ingleses neste lado do Atlântico.

Para facilitar a análise dos dados, as informações foram organizadas da seguinte maneira: optou-se por criar uma tabela com o ano dos documentos da Mesa do Desembargo do Paço, tipo de documento (requerimento de liberação, parecer do censor, testamento, lista de livros), títulos das obras, títulos de obras provindas da Inglaterra e um campo para informações obtidas sobre os requerentes ou sobre as obras. Após essa classificação do corpus em quatro tabelas distintas, sendo uma para cada pacote de documentos analisados, os dados dos romances foram organizados de acordo com os seus respectivos autores e o ano em que passaram pelo crivo da censura no Rio de Janeiro, não importando a língua ou a edição em que foram submetidos às listas dos tribunais censórios ${ }^{57}$. Em seguida, foram elaborados gráficos para auxiliar a visualização da quantidade dos tomos requeridos agrupados de acordo com seus autores e seus títulos em inglês e tabelas das obras requisitadas dispostas cronologicamente ${ }^{58}$.

${ }^{56}$ ABREU, M. "A circulação de romances como problema para a história literária". Texto do Curso Escola São Paulo de Estudos Avançados sobre a Globalização da Cultura no Século XIX realizado em Campinas, agosto de 2012.

${ }^{57}$ Esta tabela encontra-se no $\mathrm{CD}$ anexo à dissertação.

${ }^{58}$ Foi necessária a pesquisa dos títulos encontrados nas listas submetidas aos censores em diversos acervos de bibliotecas digitais como The literature network (http://www.onlineliterature.com), The Nacional Archives (www.nationalarchives.gov.uk) British Fiction, 18001829: A Database of Production, Circulation, and Reception produzido pela Cardiff University ( 
A seguir, os requerentes de romances ingleses encontrados na Mesa do Desembargo do Paço são apresentados, com o intuito de formar um pequeno catálogo dos interessados nessas obras inglesas.

A primeira caixa examinada ${ }^{59}$ contém três pacotes com pedidos de impressão, manuscritos de textos a ser impressos, requerimento de liberação de obras que estariam na Alfândega, bem como os pareceres dos censores. Nessa caixa, o requerente Ambrozio Bourdon solicita a liberação de romances ingleses.

$\mathrm{Na}$ segunda caixa, os requerentes que mencionam romances ingleses são: Carlos Durand, Carlos Robillard, Claudio João Baptista Loyseleur, Daniel Pedro Muller, Domingos Joze de Araujo Basto e Florencio Alv. de Macedo Pereira, Francisco Ignacio de Souza Queiroz, Francisco Luiz Saturnino, Freese e Blancken, Henrique Miller, e João Bonneille.

A terceira caixa ${ }^{60}$ examinada contém quatro pacotes com a numeração de 89 requerentes. Eles estão organizados em quatro pastas com alguns documentos faltantes: a primeira pasta com 27 requerentes, a segunda com 19, a terceira com 20 e a última com 13 . Os interessados em romances ingleses são: Joaquim Pereira de Almeida e Comp., Jorge Brittan, Jose Antonio Vieira de Carvalho, Joze Bernardino de Sena, Joze de la Brosse, Lozan Vial e Cia. e Manoel Antonio da Silva Serva.

http://www.british-fiction.cf.ac.uk ), o Real Gabinete Português de Leitura (http://www.realgabinete.com.br), Hathi Trust Digital Library (http://www.hathitrust.org), The Internet Archive (www.archive.org), a cronologia de textos em prosa ficcional traduzidos para o português entre 0 século XVII e $0 \quad$ XIX apresentada no site http://www.caminhosdoromance.iel.unicamp.br/cronologias/traducao.htm e o levantamento em diferentes catálogos de bibliotecas, livreiros e gabinetes de leitura existentes no Rio de Janeiro de romances ingleses que circularam no Brasil durante o século XIX realizado por Sandra Vasconcelos (http://www.caminhosdoromance.iel.unicamp.br/cronologias/inglesa.htm). A grafia dos romances citados nos documentos encontra-se, às vezes, errada e algumas listas também encontram-se ilegíveis devido à ação do tempo.

${ }^{59}$ Arquivo Nacional do Rio de Janeiro, Mesa do Desembargo do Paço, caixa 168.

${ }^{60}$ Arquivo Nacional do Rio de Janeiro, Mesa do Desembargo do Paço, caixa 170. 
$\mathrm{Na}$ quarta caixa ${ }^{61}$ examinada, foi possível encontrar pedidos de romances ingleses feitos por Joze Borges de Pinho, Jerônimo Gonçalves Guimarães e Matheus Buchanan.

Apresento a seguir as informações encontradas sobre os requerentes de romances ingleses, com o intuito de mapear as pistas de suas prováveis relações com o comércio de livros no Rio de Janeiro. O objetivo é organizar os dados biográficos dos requerentes e títulos e temáticas dos livros a eles associados.

\section{Ambrozio Bourdon e Bourdon \& Fry}

Ambrozio Bourdon, negociante francês, aparece registrado na Intendência da Polícia em 1808. Seu nome é citado em anúncios na Gazeta do Rio de Janeiro de 1815 a 1817 oferecendo mercadorias diversas e realizando leilões de produtos "que receberam ultimamente da França" e que "embarcarse-ão para Europa se não forem vendidos de 10 dias depois do presente aviso" 62

Bourdon possuía casa de negócios na Rua Direita e seu nome, embora francês, aparece na lista de negociantes ingleses do Almanaque do Rio de Janeiro do ano de $1816^{63}$, provavelmente por sua ligação comercial com Edward Winne Fry.

Fry nasceu em 1792 em uma cidade próxima a Birmingham e estabeleceu-se no Rio de Janeiro em 1810. Sua primeira ocupação foi a de

\footnotetext{
${ }^{61}$ Arquivo Nacional do Rio de Janeiro, Mesa do Desembargo do Paço, caixa 171.

${ }^{62}$ Rio de Janeiro, Gazeta do Rio de Janeiro, 2 de março de 1816.

${ }^{63}$ ALMANAQUE do Rio de Janeiro para o ano de 1816. Revista do IHGB, Rio de Janeiro, v. 268, p. 179-330, 1965. Também disponível pelo site http://hemerotecadigital.bn.br/almanachdo-rio-de-janeiro/708810. Ultimo acesso em maio de 2012.
} 
empregado da firma comercial House of Cunningham Dun e $\mathrm{Co}^{64}$. A data do início da sociedade entre Ambrozio Bourdon e Edward Winnne Fry foi 1812, de acordo com carta publicada por esse último em 1839:

The decease of my much respected friend and partner Mr. Ambrose Bourdon has left me the only survivor of my late firm, I now take the liberty to appraise you that it is my intention to continue the business on the same principles as have been followed during a period of twenty seven years and under the firm of Edward Fry. ${ }^{65}$

A sociedade entre esses dois negociantes oferecia produtos variados vindos de Londres e promovia leilões. Ali pessoas interessadas em comprar passagens para a Europa, bem como enviar produtos ou cartas, poderiam encontrar os serviços.

Essa sociedade contava com outros integrantes que não são mencionados nos anúncios de produtos. Podemos saber pelo aviso publicado no Diário do Rio de Janeiro em 1827: "Participa-se ao Publico, que Pedro Gautreau Junior, retirou-se da sociedade que teve com Bourdon e Fry, no dia 31 de Dezembro proximo passado." 66

A casa Bourdon \& Fry também realizava leilões de produtos como flores, castiçais, carteiras, sapatos, leques, pérolas, brinquedos, camisas, fitas, etc., para outros negociantes como J.J. Dodsworth e C. Cannel. ${ }^{67}$

\footnotetext{
${ }^{64}$ DIAS, Cleber Augusto Gonçalves. História do Lazer na Natureza do Rio de Janeiro. (2011) Tese de Doutorado apresentada à Pós-Graduação da Faculdade de Educação Física da Universidade Estadual de Campinas.

65 "A morte do meu respeitável amigo e parceiro Sr. Ambrose Bourdon me deixou como único sobrevivente da firma e tomo a liberdade de informar que é minha intenção continuar os negócios de acordo com os mesmos princípios que tivemos sob a firma de nome Edward Fry durante vinte e sete anos." A carta completa pode ser encontrada no site www.digitallibraryvillanova.edu. (tradução livre)
}

${ }^{66}$ Rio de Janeiro, Diário do Rio de Janeiro, 17 de março de 1827.

\footnotetext{
${ }^{67}$ No dia 2 de novembro de 1825, Dodsworth anuncia no Diário do Rio de Janeiro um leilão de produtos variados na casa de Bourdon \& Fry. Em 19 de janeiro de 1827, Cannel faz leilão de braças de amarras na mesma casa.
} 
No ano de 1816, Ambrozio Bourdon declara a lista de livros que trouxe para negócios à Mesa do Desembargo do Paço. A lista é impressionante com cerca de 400 títulos diversos, incluindo dicionários, livros de mitologia, de história e romances. Entre os romances trazidos constam obras dos autores Daniel Defoe, Maria Edgeworth, Henry Fielding, Oliver Goldsmith, Elizabeth Helme, Samuel Richardson, Walter Scott, Laurence Sterne, Jonathan Swift e Maria Julia Young.

Fry faleceu em junho de 1849, deixando três filhos: Joseph, Henry Ambrose e Alexander ${ }^{68}$ Interessante destacar que Edward Fry batizou um dos seus filhos como Ambrose, mesmo nome do seu finado amigo e sócio. Pode-se sugerir a relação de compadrio entre esses dois sócios também. Como Brügger explica, no final do século XVIII, era um costume muito comum a atribuição às crianças dos nomes dos padrinhos no Brasil. ${ }^{69}$

\section{Carlos Durand}

No dia 29 de setembro de 1821, a Gazeta anuncia que o comerciante Jorge João Dodsworth faria no dia 01 de outubro daquele ano um leilão dos bens do então falecido Carlos Durand.

Carlos Durand, ou Charles Durand, natural da Normandia, embarcou da Holanda para o Brasil e estabeleceu sua casa de negócios em $1816^{70}$. Por

\footnotetext{
68 "Edward Winne Fry of Thronhill House, Handsworth, near Birmingham, formely of Rio de Janeiro, Brazil, Born at Charterhouse Square, London, 12 April, (...)died at Thornhill House Handsworth on 30 May bur. At St. Mary's Handsworth, 5 June 1849, will dated 1849 proved by his sons." In Visitation of England and Wales, disponível no site www.archive.org . Acessado em: 07 de maio de 2012.
}

${ }^{69}$ BRÜGGER, Silvia Maria Jardim. Minas patriarcal - Família e sociedade (São João Del Rei Séculos XVIII e XIX). São Paulo, Annablume, 2007, p.314.

70 NEVES, Lucia Maria Bastos Pereira das. "Livreiros franceses no Rio de Janeiro 1799 1824." http://www.portcom.intercom.org.br/pdfs/bb3aea30006796253008218e5bdda0c1.pdf. Acesso em 7 de fevereiro de 2013 
meio da leitura da Gazeta do Rio de Janeiro, sabemos que Carlos Durand inicialmente tinha um estabelecimento na Rua do Ouvidor, n. 18. Já em 1817, anuncia na Gazeta do Rio de Janeiro sua loja na Rua do Ouvidor $n^{\circ} 28$. Em 1819, anuncia seu armazém na Rua Direita $n^{\circ} 9$. Seus anúncios são constantes entre 1816 e 1820. Como vários outros negociantes de livros no Rio de Janeiro oitocentista, Durand negociava artigos variados como enfeites para mulheres, lenços, relógios, águas de cheiro, vinhos, tecidos e produtos de química e farmácia trazidos da França.

Carlos Durand fez requerimentos de livros ingleses nos anos 1816, 1817 e 1819. Como resposta a um destes pedidos em 1819, o censor chega a repreender o requerente ${ }^{71}$ :

a lista de livros francezes exhibida por carlos durand he tao defeituoza, e informa, que merecia ser rejeitada e obrigando o supplente a apresentar outra que fosse exata ou menos imperfeita. Achasse titulos truncados, outros que não se podem ler por mal escriptos, muitos repetidos mais de das vezes, falhao os nomes dos authores e o numero dos volumes de cada obra. Semelhantes defeitos não só difficultão a censura dos livros como taobem suscitão desconfianças e perplexidades no espirito do censor, que se attribui á malicia e dólo o que muitas vezes he effeito de impericia ou negligencia dos escreventes. Nestes termos tomei o partido de fazer huma lista separada dos livros que me são desconhecidos ou suspeitos com algumas breves notas tendentes a facilitar o exame e que se deva proceder sobre elles. $^{72}$

Em 1816, requer a liberação de Aventuras de Robinson, de Daniel Defoe. Em 1818, faz novamente o pedido de liberação da obra de Defoe e adiciona a obra Vicar of Wakefield, de Oliver Goldsmith, à sua lista.

\footnotetext{
${ }^{71}$ A grafia do documento foi mantida.

${ }^{72}$ Mesa do Desembargo do Paço, caixa 169, pacote 1, documento 4.
} 
Em julho de 1820, a casa Durand e Cia cessa suas atividades ${ }^{73}$, deixando Francisco Vial e Francisco Scheiner como administradores de possíveis credores como podemos observar no anúncio abaixo:

"Francisco Vial, e Francisco Scheiner, partecipão que elles forão nomedos administrados dos bens cedidos, por Carlos Durand, pertencidos à caza de Carlos Durand, e comp., e rogão a todas as pessoas que tiverem contas com a dita caza que as apresentem a elles ditos administradores no termo de hum mez contado da data deste annuncio, para serem contemplados nos rateios a que devem proceder." Gazeta do Rio de Janeiro, 5 de dezembro de 1821.

\section{Carlos Robillard}

Morador do Rio de Janeiro e proprietário de terras em Ubatuba entre 1820 e 1830. De acordo com Maria Luisa Marcílio, Carlos José Robillard, francês vindo da ilha de São Domingos, morador do Rio de Janeiro, possivelmente teria recebido doação de sesmarias em Ubatuba e ali instalado plantações.

Como o decreto de 25 de novembro de 1808 permitiu a doação de sesmarias a estrangeiros, os europeus, não portugueses que foram chegando, logo iam solicitando e recebendo largas sesmarias, onde instalaram plantações de café, mescladas com roças de alimentos. É o caso de [...] ou de Carlos José Robillard, que foi acumulando várias parcelas de sesmarias e em posses, as quais acabaram por se transformar em sua propriedade. $^{74}$

Carlos Robilard pediu licença para importar diversos livros e gravuras, incluindo o romance inglês Tom Jones de Henry Fielding e as obras de Shakespeare.

\footnotetext{
${ }^{73}$ TRIGUEIRO, António Minguel. As ordens militares portuguesas no império do Brasil. http://www.conteudos.easysite.com.pt/files/48/ficheiros/emblematica/AsOrdens_MilitaresPortug uesasnolmperiodoBrasil_revistaMoeda.pdf.pdf Acesso em: 7 de fevereiro de 2013.

${ }^{74}$ MARCILIO, Maria Luiza. Caiçara: terra e população, Estudos de demografia histórica e da história social de Ubatuba, São Paulo: Edições Paulinas/CEDHAL, 1986. p. 70.
} 


\section{Lazan (Lezan) Vial e Cia.}

Francisco Vial veio de Bordeaux em 1817 e estabeleceu sua casa de negócios com Francisco Scheiner na Rua do Ouvidor, $n^{\circ} 28$. Responsável por leilões e por administrar encomendas, Lazan Vial e Cia. pede a liberação de aproximadamente 100 títulos, entre eles duas obras alemãs (a peça Marie Stuart de Schiller e uma obra de Goethe) e as obras inglesas The Vicar of Wakefield, de Oliver Goldsmith, e The Sentimental Journey, de Laurence Sterne. Esta firma publica diversos anúncios sobre a chegada de sal, manteiga, seda, vinhos e produtos variados na seção de "Notícias Marítimas" na Gazeta do Rio de Janeiro.

\section{Claudio João Baptista Loyseleur}

Boticário de origem francesa ${ }^{75}$, Claudio João Baptista Loyseleur fez um requerimento para trazer sua biblioteca particular em novembro de 1818. Afirmava ter "vindo neste pais para nelle se estabelecer e residir que trouxe a sua bibliotheca a qual se compoem de livros mencionados"76. Esta lista contém cerca de 140 títulos variados, entre eles volumes de assuntos diversos como geografia, história, física, matemática, história natural, dicionários de inglês, francês e latim, tratados de anatomia, arquitetura e ótica, além de obras de Racine, Crebillon, Boileau, Condillac, Molière. Na lista enviada para a Mesa do Desembargo, podemos encontrar dois romances ingleses: Robinson Crusoe e The History of Tom Jones, além do periódico inglês The Rambler, supostamente para uso próprio.

\footnotetext{
${ }^{75}$ BLANCHE, Henri Boullier de. Inventário Sumário dos documentos da Secretaria de Estado da Marinha. Rio de Janeiro: Ministério da Justiça e Negócios Interiores, Arquivo Nacional, 1930.

${ }^{76}$ Mesa do Desembargo do Paço, caixa 169, pacote 1, documento 8.
} 
Estabeleceu sua loja na rua da Candelária, $n^{\circ} 2$ em $1825^{77}$. Em 1829, publica anúncio à procura de um escravo para trabalhar ali ${ }^{78}$. Ofereceu seus serviços de droguista no mesmo local até 1830 , ano em que faleceu, como o Jornal do Comércio anuncia na seção de arrematações ${ }^{79}$. Seus bens, incluindo seus livros e três escravos, foram leiloados a pedido do cônsul da França na casa de J. J. Dodsworth a partir de junho de 1830.

\section{Daniel Pedro Muller}

Daniel Pedro Muller, engenheiro de família rica, nasceu em alto mar durante a viagem que seus pais fizeram da Alemanha para se estabelecer em Portugal na década de 80 do século XVIII ${ }^{80}$. Seu pai, João Guilherme Cristiano Muller $^{81}$, natural da Alemanha, foi o primeiro pastor luterano da Congregação

\footnotetext{
${ }^{77}$ Rio de Janeiro. Diário Mercantil, 12 de janeiro de 1825.
}

${ }^{78}$ Courrier Du Brèsil: Feuille Politique, Commerciale et Littéraire, 30 de maio de 1829.

79 "Arrematações - Nos dias 2 e 3 de junho próximo, ha de ser rematado por conta de quem pretender, a quem mais der, o estabelecimento de drogas do finado Claudio Loiyseleur, rua da Candellaria, $n^{\circ}$ 2: as pessoas a quem convier o negócio, podem comparecer nos dias mencionados pelas 10 horas da manhã, na sobredita morada: pode-se ver o estabelecimento com o inventario, e as condições da venda, todos os dias"Jornal do Commercio, 28 de maio de 1830.

${ }^{80}$ Sua data de nascimento é incerta, havendo grande divergência entre seus biógrafos. Antônio Egydio Martins afirma que Müller teria nascido no ano de 1782. MARTINS, Antônio Egídio. São Paulo Antigo (1554-1910). São Paulo: Paz \& Terra, 2003. Sacramento Blake dá o ano de 1785. SACRAMENTO BLAKE, Augusto Victorio Alves. Diccionario Bibliographico Brazileiro. Rio de Janeiro: Imprensa Nacional, 1898, v.2, p. 160. Já Honório de Syllos julgou 1775 ser o ano mais provável do nascimento de Müller. SYLOS, Honório de. Introdução. In: MULLER, Daniel Pedro. Ensaio d'um quadro estatístico da Provincia de S. Paulo. 3 ed. facsimilada. São Paulo: Governo do Estado, 1978, p. XV.)

81 João Guilherme Cristiano Muller ou John William Christian Muller atuou como censor em Portugal, como se pode ler em ABREU, Marcia. "Effluvios pestiferos da perversidade do Século", leituras de Werther no mundo luso-brasileiro, Revista de Letras, Universidade Estadual Paulista, vol. 46, n. 2 (jul-dez 2006), p. 78-95. 
Evangélica Alemã de Lisboa e também Diretor da Academia Real das Ciências de Lisboa.

Enviado ao Brasil como ajudante de ordens do governador, Daniel Pedro Muller passou a residir em São Paulo de Piratininga a partir de 1802. Muller foi um militar com várias condecorações e, além disso, de acordo com Toledo ${ }^{82}$, trabalhou em várias obras importantes de engenharia em São Paulo, inclusive na elaboração da estatística da província, bem como o Mappa Chorographico da Província de São Paulo ${ }^{83}$.

Em 1817, faz um requerimento de livros para uso próprio com cerca de 700 títulos em francês, português e alemão. Entre eles, a obra Pamela oder die belohnte Tugend ${ }^{84}$. Lucia Maria Bastos P. Neves sugere que o capital simbólico acumulado por Muller o situava num lugar proeminente como membro da restrita elite cultural da Corte. ${ }^{85}$

A partir de 1838, escreveu obras em diversas áreas do conhecimento, como Princípios de Grammatica da língua portugueza; Cathecismos de Arithimetica; Cathecismos de Geographia e Cathecismos de História Natural.

Foi também o primeiro diretor do Gabinete Topográfico criado na província de São Paulo e foi encarregado de diversos melhoramentos nessa

82 TOLEDO, Benedito Lima de. São Paulo: 3 cidades em um século. São Paulo: Livraria duas cidades, 1981.

${ }^{83}$ BEIER, José Rogério. Daniel Pedro Müller e a trajetória de seu Mappa Chorographico da Provincia de São Paulo: da encomenda à impressão e apresentação à Assembleia Legislativa da Província de São Paulo (1835-1842). Apresentação no IV Simpósio Iberoamericano de História da Cartografia, realizado na Biblioteca Nacional de Portugal de 11 a 14 de setembro de 2013.

${ }^{84}$ Consta na lista o seguinte nome: "Richardson lehvende tugiond". Pode-se deduzir que este é Pamela oder die belohnte Tugend, o título em alemão de Pamela, de Samuel Richardson.

${ }^{85}$ NEVES, Lucia Maria Bastos P. "Luzes nas Bibliotecas de Francisco Agostinho Gomes e Daniel Pedro Muller, Dois Intelectuais Luso-Brasileiros". Comunicação no site http://cvc.instituto-camoes.pt/eaar/coloquio/comunicacoes/lucia_maria_bastos_neves.pdf. Acessado em: 5 de março de 2013. 
cidade. Faleceu em São Paulo afogado no rio Pinheiros em 1841, deixando seis filhos de seu primeiro casamento.

\section{Domingos Joze de Araujo Basto}

Nasceu em 1777 em São Miguel de Refoios, ${ }^{86}$ Portugal. Em 1816, faz um requerimento de liberação de seus livros, apresentando-se como um negociante de mudança para Porto Alegre. Na sua lista de livros, podemos verificar obras religiosas, dicionários, poesias e romances. Ele requer a liberação de Pamela de Richardson, de Memórias do Cavaleiro de Kilpar, o homem raro atribuído a Henry Fielding, porém de possível autoria de J. Gain de Montagnac; Viagens de Guliver de Jonathan Swift, e Robinson Crusoe de Daniel Defoe.

Como intelectual que era, conseguiu ser juiz de paz ${ }^{87}$ em Porto Alegre ${ }^{88}$ e ali faleceu em 1843.

Florêncio Alv. de Macedo Pereira

${ }^{86}$ ESTEVES, Mauro. LIVRO 18 (1841 - 1844) - Sinopse dos Inventários e Testamentos de Porto Alegre RS - 1776 - 1852. Disponível em http://pt.scribd.com/doc/45971157/17/LIVRO18-1841-1844. Acessado em: 8 de maio de 2013.

${ }^{87}$ Domingos Joze de Araujo Bastos é citado em um anúncio do Diário do Rio de Janeiro de 21 de novembro de 1833: "Entra mais em julgamento, também a revelia, a ré ausenta a preta Carolina, escrava da preta Catharia Maria, accusada pela justiça publica como autora do crime ferimento leve feito com os dentes em Domingos José de Araújo Bastos, no dia 3 de janeiro d'este ano, na taberna da rua do Sacco dos Alferes, esquina da rua da União."

${ }^{88}$ TRAMONTINI, Marcos Justo. A colônia de São Leopoldo: A organização social dos imigrantes na fase pioneira (1824-1850) - Tese de Doutorado - UNISINOS - Programa de PósGraduação em História. Disponível em http://www.siters.com.br/Obra/Capitulo.asp?ldCapitulo=3\&NomeSecao=Historia Acessado em: 10 de maio de 2013. 
Padre, professor de latim e filosofia na Corte, subscreveu o primeiro ano dos Annaes das Sciencias, das Artes e das Letras ${ }^{89}$. Florêncio Macedo Pereira pede liberação de livros de uma lista de duas páginas em 1820. Entre estes livros, podemos encontrar Robinson Crusoe.

\section{Coronel Francisco Ignácio de Souza Queiroz}

Francisco Ignácio de Souza Queiros foi um grande produtor de açúcar e um dos chefes militares do movimento contra José Bonifácio em 1822, chamado bernarda paulistana. Morreu em 1831, deixando um inventário em que constavam cerca de 230 escravos.

Francisco Ignácio de Souza Queiroz escreve seu requerimento para liberação de livros vindos da cidade do Porto e envio para Santos. A lista de Francisco inclui Robinson Crusoe de Daniel Defoe, Tom Jones de Henry Fielding, Les Choses telles qu'elles sont, ou Les Aventures de Caleb Williams de William Godwin, Alberto, ou o deserto de Strathnavern de Elizabeth Helme e Celestine, possivelmente obra de Charlotte Turner Smith.

\section{Francisco Luis Saturnino}

Francisco Luis Saturnino chegou ao Brasil aos 13 anos de idade, mudando-se para Vila Rica em 1788. Em 1789, estabelece-se na rua do Ouvidor no Rio de Janeiro, onde foi nomeado professor régio de primeiras letras, abrindo uma escola de instrução primária ${ }^{90}$. Abriu uma livraria que, como as de outros negociantes do ramo, oferecia desenhos, estampas, carteiras e

\footnotetext{
${ }^{89}$ Annaes das Sciencias, das Artes e das Letras foi um periódico publicado na França entre 1818 e 1822. Tinha como assinantes portugueses residentes em Paris, nos arquipélagos dos Açores e Madeira, habitantes do Brasil, inclusive o próprio D. João. Em: REIS, Fernando Egídio. As ciências nos periódicos portugueses de finais do séc. XVIII e princípios do séc. XIX. 2004. Trabalho apresentado em Ciências da Comunicação em Congresso na Covilhã (CCCC 2004), Covilhã, 2004. Disponível em http://www.proformar.org/revista/edicao_13/divulga_cienc_portugal.pdf Acesso em 13 de dezembro de 2012.

${ }^{90}$ Macedo, J. M. Memórias da Rua do Ouvidor. Brasília: Editora Universidade de Brasília, 1988, p. 84.
} 
corretagem de terrenos no mesmo local. Podemos supor a importância deste sobrado devido ao relato de Joaquim Manuel de Macedo em Memórias da Rua do Ouvidor, onde ele recorda um local com "lembrança doce, mesmo porque é lembrança de senhores e de doces". Nessa mesma casa, havia um estabelecimento das primeiras e "incomparáveis" doceiras do Rio de Janeiro, as senhoras Paracatu.

Em 1820, Francisco Luiz Saturnino pede à Mesa do Desembargo do Paço a liberação de uma extensa lista de livros, entre eles Tom Jones e Gulliver's Travels.

Em 1822, sua esposa falece e Francisco decide casar-se novamente. Querendo contrair segundas núpcias, partilha os bens de sua falecida esposa entre os filhos João Pedro Ferreira da Veiga e Evaristo Ferreira da Veiga. Nesse mesmo ano, os dois irmãos adquirem a loja de livros de Manoel Joaquim da Silva Porto, na rua da Quitanda, 202, esquina com São Pedro. Supõe-se que destino destes irmãos livreiros mostra o quão lucrativa a venda de obras literárias poderia ser.

\section{Freese e Blancken ou Freeze Blankenhagen}

John Henry Freese foi comerciante em Londres e no Rio de Janeiro. No início do século XIX, ele muda-se para Nova Friburgo, onde se torna diretor de um colégio. Publica diversas obras, entre elas The Cambist Compendium, Rio Circular, Elements of conversation in four languages, The commercial class book, How to educate the youth of Brazil, Compêndio de Geographia e História, $1^{\circ}$ Livro de Arithmetica, e Instrucções Innocentes e Doutrinaes.

J. C. Blankenhagen aparece na Gazeta do Rio de Janeiro como um dos doadores de fundos para combater os franceses ${ }^{91}$.

Freeze Blankenhagen, firma alemã, possuía uma loja na Rua da Alfândega ${ }^{92}$ São apontados como um dos primeiros alemães a estabelecerem negócios no Rio de

${ }^{91}$ Gazeta do Rio de Janeiro, 15 de fevereiro de 1809. 
Janeiro. Assim como outros negociantes estrangeiros, possuíam uma casa de vendas de fazendas e outros artigos na Rua da Alfândega ${ }^{93}$.

Os sócios Freeze e Blankenhagen fizeram requerimentos de liberação de livros em 1810, 1811 e 1815. Em 1810, requerem a liberação de obras de Fielding, de Swift e uma obra chamada Adeline. Pode-se supor se tratar de Adelina e Theodoro, ou a Abadia de Saint Clair, The Romance of the Forest (1791), talvez em uma versão francesa. ${ }^{94}$

\section{Henrique Muller (Miller)}

Responsável por uma casa de negócios de diversos produtos na Rua dos Pescadores, $n^{\circ}$ 6, Muller e Cia (ou Miller), anuncia de 1809 a 1831 seus diversos itens na Gazeta do Rio de Janeiro. Já em 1809, seu nome é citado na contribuição de negociantes ingleses no Rio de Janeiro para o combate aos franceses ${ }^{95}$. Negociava vinhos, fazendas, papel, "serveja", "agoardente", tecidos, azeite, batatas, manteiga, sabão, ferro e passagens para a Inglaterra. Não anunciou livros nos periódicos consultados para esta pesquisa; porém, Henrique Muller aponta ter seis caixotes esperando a permissão da Mesa do Desembargo em 1818. Sua lista nesse mesmo órgão inclui obras variadas, como volumes de história, de economia, de história natural e vários títulos vocacionais, como arte de fazer camisas, arte de alfaiate, arte de fazer selas,

92 SCHRÖDER, F., DREHER, M.N., A imigração alemã para o sul do Brasil até 1859. São Leopolso: EDIPUCRS, 2003, p. 33.

${ }^{93}$ SILVA, C. B. "Uma perspectiva atlântica: a circulação de mercadorias no Rio de Janeiro após a transferência da Corte portuguesa para o Brasil (1808-1821)." Revista Navigator - Subsídios para a História Marítima do Brasil, volume 8, N. 16, 2012.p. 28

${ }^{94}$ VASCONCELOS, S. G. T. Romances ingleses em circulação no Brasil durante o Séc. XIX. Disponível em: http://www.unicamp.br/iel/memoria/Ensaios/Sandra/sandralev.htm. Acesso em: 03 de abril de. 2013.

${ }^{95}$ Gazeta do Rio de Janeiro, 15 de fevereiro de 1809. 
arte do telhador e outras ${ }^{96}$, além de um volume de Beauties of Sterne. É interessante notar que estes livros tinham como público alvo pessoas interessadas em aprender ou aperfeiçoar seus negócios.

De acordo com Araujo ${ }^{97}$, este inglês ficou longo período no Rio de Janeiro, chegando até mesmo a ser preso em companhia de outros ingleses em 1838 por "serem ébrios, vadios e desordeiros".

\title{
Izabella Morice
}

Izabella (Isabella) Gibbon, nascida em Aberdeen em 1781, filha de um negociante, casou-se com Alexander Morice em 1810 no Rio de Janeiro ${ }^{98}$. A então senhora Morice foi a única mulher a fazer um requerimento de romances ingleses nos documentos analisados para este trabalho.

Em 1810, além de listar as comédias de Shakespeare, The Spectator e The Rambler, ela inclui as obras de Laurence Sterne, vindas direto da Inglaterra. Supõe-se que estes livros eram para uso próprio.

\section{Jerônimo Gonçalves Guimarães}

\begin{abstract}
96 "arte de fazer porcelaine, arte de beneficiar louros, arte de fazer panno de linho, arte de alfaiate, arte de fazer paipas de pitar tabaco, fabrica de ancoras, arte de fazer camisas, fabrica de goma para lavanderias, arte de fazer sellas, arte de pintar sedas, arte de fazer mantas, arte de extrahir pedras, arte do tintador, arte do bordador, arte do seriqueiro, arte do surrador de pelles, arte do telhador, arte do bauleiro, arte do marinheiro, historia da origem de confeitorias mermiccelli, arte de distillar licores, arte de distillar agoardentes, arte de queimar cal, arte de pintar vidros, arte de fazer panno de lãa, arte de refinar assucar, arte de cabellereiro, arte de fazer velas". Mantive a ortografia apresentada no documento.
\end{abstract}

${ }^{97}$ ARAUJO, Carlos Eduardo Moreira de. Cárceres Imperiais: A casa de Correção do Rio de Janeiro. Seus detentos e o sistema prisional no império, 1830 - 1861. Tese (Doutorado) Instituto de Filosofia e Ciências Humanas, Universidade Estadual de Campinas, Campinas, 2009, p. 82.

${ }^{98}$ A Genealogical Account of the Descendants of James Young, Merchant Burgess of Aberdeen and Rachel Cruickshank, His Wife, 1697-1893: With Notes as to Many of the Families with which They are Connected, p. 177. 
O requerente Jerônimo Gonçalves Guimarães pede permissão para receber os livros enviados da Bahia pelo livreiro Manoel Antonio da Silva Serva em 1817.

Jerônimo Gonçalves Guimarães estabeleceu sua loja na Rua do Sabão. Possui três grandes listas de livros na Mesa do Desembargo do Paço. A primeira lista data de 1817 e sua nota de frete segue a seguir.

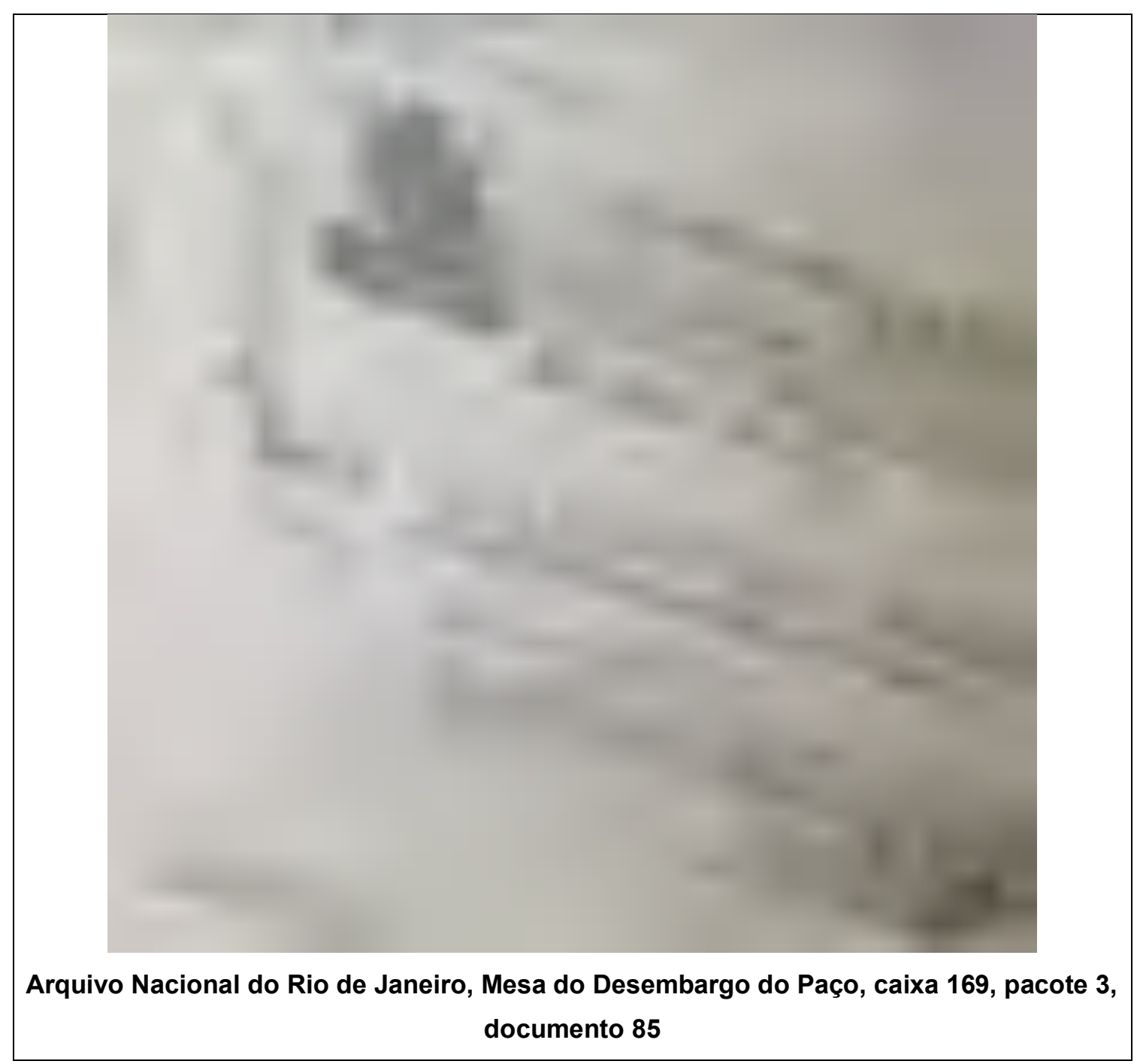

Neste primeiro requerimento, entre diversas obras, Jerônimo Gonçalves Guimarães pedia a liberação de romances ingleses como Viagens de Gulliver de Jonathan Swift, Robinson Crusoe de Daniel Defoe e Ema ou a filha do 
desgosto, uma novela epistolar publicada anonimamente em Londres em $1773^{99}$.

Os requerimentos de 1818 e 1819 apontam diversas obras trazidas da cidade do Porto. Nessa extensa lista não foram encontrados romances ingleses. Nesse mesmo ano, publica na Gazeta do Rio de Janeiro e Diário do Rio de Janeiro anúncios de diversos livros, incluindo "livros de diversas faculdades" 100 .

\section{Manoel Antonio da Silva Serva}

Manoel Antonio da Silva Serva nasceu em Portugal e mudou-se para o Brasil no final do século XVIII. Atuou como comerciante de livros na Bahia e foi o responsável pela segunda tipografia do Brasil.

Silva Serva teve projetos de um jornal e uma biblioteca pública. Em 1820, ele importa as obras Aventuras de Robinson Crusoe de Daniel Defoe, História de Adele e Teodoro de Ann Radcliffe para levar para a Bahia. Seus requerimentos cessam em 1821, quando as viúvas Serva e Carvalho escrevem à Mesa do Desembargo do Paço, pedindo a liberação de livros do falecido marido e sogro ${ }^{101}$.

\section{João Bonneille}

${ }^{99}$ VASCONCELOS, S. G. T. Romances ingleses em circulação no Brasil durante o Séc. XIX. Disponível em: http://www.unicamp.br/iel/memoria/Ensaios/Sandra/sandralev.htm. Acesso em: 03 de abril de. 2013.

${ }^{100}$ Gazeta do Rio de Janeiro, 24 de junho de 1818.

101 "Dizem Viúva Serva e Carvalho da Cidade da Bahia, que despachando seu Marido e Sogro Manoel Antonio da Silva Serva vários caixões de livros para sortimento do seu negócio, d'entre estes se mandarão reter na Alfândega da Bahia por onde se fez o despacho, as que constão da Relação junta, para o fim de serem remetidos como effeito forão para a Secretaria d'Este Tribunal da Meza do Dezembargo do Paço (...) e porque as supplicantes querem concluir o Inventário do dito seu Marido e Sogro." Mesa do Desembargo do Paço, caixa 170, pacote 2 , documento 86 . 
João Bonneille foi o primeiro responsável pela prática postal no Rio de Janeiro. De acordo com Rizzini, "em 1821, ensaiou-se, sem sucesso, a pequena posta no Rio, concedendo o governo a João Baptista Bonneille privilégio para colocar caixas nos pontos que lhe achasse conveniente." ${ }^{102}$

Em 1824, João Bonneille se apresenta como negociante francês e pede a liberação de uma coleção vinda da Europa. O parecer do censor de abril do mesmo ano atesta que uma das obras pedidas, Lettres Peruviannes, é proibida, e outras que "não tenha noticia" ${ }^{103}$. O censor nada fala sobre as obras inglesas Beautes, de Sterne, Lady Mathilde, suite de Simple Histoire, de Elizabeth Inchbald.

\section{Joaquim Pereira de Almeida e C.}

Casa de venda de escravos de Lisboa, a firma Joaquim Pereira de Almeida e Cia teve a permissão do regente D. João para funcionar no Rio de Janeiro em 1808. Possuíam um escritório na Rua Direita, $N^{\circ} 53$, e foram responsáveis pelas ações da Fábrica de Pólvora na década de 20. De acordo com Carlos Gabriel Guimarães, a firma se tornou a representante oficial do Banco do Brasil em Portugal.

Seu crescimento pareceu evidente no período joanino. Se em 1809 a companhia estava no prédio 11, em 1823 aparece como proprietária dos prédios de 9 a 12 na referida rua da Emenda. Após 1823, com a morte de Joaquim Pereira de Almeida e Antonio Pereira de Almeida, desapareceria. ${ }^{104}$

${ }^{102}$ RIZZINI, C. O livro, o jornal e a tipografia no Brasil: 1500 - 1822. Imprensa Oficial do Estado S. A. IMESP, São Paulo, 1988. p. 120.

${ }^{103}$ Arquivo Nacional do Rio de Janeiro, Mesa do Desembargo do Paço, caixa 169, pacote 03 , documento 93.

${ }^{104}$ GUIMARÃES, C. G. "O "comércio de carne humana" no Rio de Janeiro: o negócio do tráfico negreiro e João Rodrigues Pereira de Almeida e da firma Joaquim Pereira de Almeida \& Co., 1808-1830 - primeiros esboços. " em África passado e presente: II Encontro de Estudos Africanos da UFF [recurso eletrônico] / org. Ribeiro, Alexandre; Gebara, Alexsander; Bittencourt, Marcelo - Niterói: PGHISTÓRIA-UFF.2010. Disponível em http://www.historia.uff.br/stricto/files/public_ppgh/hol_2010_AfricaPassadoPresente.pdf Ultimo acesso em abril de 2012. 
Em 1817, essa empresa pede a liberação de uma caixa de livros que inclui As Aventuras de Robinson Crusoe de Daniel Defoe.

\section{Jorge Brittain}

A sociedade comercial de George Brittain Scheiner e cia. anunciou diversas vezes leilões próprios e de outras firmas de ferragens, cobre, pregos, espelhos e papel de embrulhar, entre 1822 e 1845, no Diário do Rio de Janeiro $^{105}$ na casa da rua do Sabão, 393.

Em 1818, Brittain Scheiner também requer o despacho dos romances Waverley e Rob Roy de Walter Scott, assim como obras de Sterne.

\section{José Antonio Vieira de Carvalho}

José Antonio Vieira de Carvalho foi coronel, governador do Forte do Itapema e também juiz, vereador e presidente da Câmara de Santos desde 1808. Os romances ingleses que quis despachar para Santos em 1820 foram Luiza, ou a cabana no deserto, de Elizabeth Helme, Julia, podendo ser esta a obra Julia, ou os subterrâneos do castelo de Mazzini de Ann Radcliffe ${ }^{106}$. A título de curiosidade, registre-se que este requerente também possuía um volume da obra francesa A Bela e a Fera.

\footnotetext{
${ }^{105}$ Carlos Cannel realizou leilões em casa de G. Brittain, Scheiner e Comp, assim como o fez J. J. Dodsworth. Anúncios destes leilões são encontrados no Diário do Rio de Janeiro, 22 de maio de 1824 e em 1830.
}

${ }^{106}$ VASCONCELOS, S. G. T. Romances ingleses em circulação no Brasil durante o Séc. XIX. Disponível em: http://www.unicamp.br/iel/memoria/Ensaios/Sandra/sandralev.htm. Acesso em: 03 de abril de 2013. 


\section{Joze Bernardino de Sena}

Jozé Bernardino de Sena, funcionário da secretaria da tesouraria, pede licença para transportar seus livros para São Paulo em 1819. O motivo da sua mudança: "Diz Joze Bernardino de Sena, que elle Supplente foi perciso recolher-se dessa Corte para esta Cidade de S. Paulo, a tomar ares livres, por causa das suas moléstias, tem consigo hum Caixão de Livros de seu uso ${ }^{107, .}$

Sua lista conta com diversos títulos ingleses: Caleb Williams de William Godwin, poemas de Robert Bloomfield, obras de Fielding, Guy Mannering, Rob Roy, The Minstrelsy of the Scottish Border, The Lay of the Last Minstrel, Roderick and Waterloo, Rokeby, Tales of my Landlord, Marmion, Waverley de Walter Scott, Frankenstein de Mary Shelley, The Adventures of Roderick Random de Tobias Smollet, The Vicar of Wakefield de Oliver Goldsmith, Tristram Shandy de Laurence Sterne, Thaddeus of Warsaw de Jane Porter, Gulliver's Travels de Jonathan Swift, e as obras de Edgeworth: Popular Moral Tales, The Modern Griselda ${ }^{108}$, Irish Bulls, Comic Dramas, Leonora, Harrington's Thoughts on Boxes.

\section{Joze Borges de Pinho}

Proprietário de uma loja de livros na Rua do Ouvidor, em 1814, Jozé Borges de Pinho associou-se a Manuel Mandillo, um dos primeiros livreiros no Rio de Janeiro. Em 1815, requer a liberação de obras variadas, incluindo Pamela de Richardson. Pode-se concluir que esta obra poderia ser encontrada na loja de Mandillo, defronte da Capela dos Terceiros de N. S. do Carmo, de acordo com anúncios do jornal Diário do Rio de Janeiro.

\footnotetext{
${ }^{107}$ Arquivo Nacional do Rio de Janeiro, Mesa do Desembargo do Paço, caixa 170, pacote 01 , documento 25 .

${ }^{108} \mathrm{Na}$ lista de despachos, este romance é escrito como Grisalda.
} 


\section{Joze de La Brosse}

Joze de La Brosse, estabelecido na Rua do Rosário, $n^{\circ} 12$, declarou a extensa lista de quatro caixas de livros a serem despachados em 1818. Entre os livros, três romances ingleses são mencionados: Aventuras de Robinson Crusoe de Daniel Defoe, Glovina de Lady Mary Morgan e Emilie de Coulanges de Maria Edgeworth. Este negociante foi mencionado sete vezes no Diário do Rio de Janeiro na década de 20 como negociante de leilões, casa, embarcações e chácaras.

\section{Matheus Buchanan}

Infelizmente, muitas informações sobre a vida deste escocês que morou no Rio de Janeiro na segunda década do século XIX são incertas. Sabemos que em 18 de fevereiro de 1819 Buchanan tinha na Alfândega da Corte do Rio de Janeiro seis baús com livros. Sua lista contém poemas, drama, dicionário de português, livros de química e medicina e os romances ingleses Mansfield Park de Jane Austen, A Sentimental Journey de Laurence Sterne e as obras inglesas Gertrude of Wyoming de Thomas Campbell, Lalla Rookh de Thomas Moore e Brighton or the Steyne de Thomas Brown.

Por meio de anúncios, também sabemos que morou até 1821 em uma casa da Rua do Ouvidor, $n^{\circ} 25$, quando sofre uma ação de despejo. Seus bens são leiloados, como anunciado no Diário do Rio de Janeiro de 26 de junho de 1821 (ortografia original mantida):

A porta da Alfândega das dez para honze horas do dia 26 de junho, se faz leilão para ser arrematada infalivelmente a chácara que foi do falido Matheos Buchanan, sita aos Arcos Velhos, na rua da Pedreira da Gloria, por ordem dos Administradores.

\section{Pedro Affonso de Carvalho}

Este português foi um dos primeiros taquígrafos no Brasil de acordo com os Annaes Constituinte de 1823. Foi também professor de taquigrafia e fez o 
requerimento de um livro descrito como sendo do autor Samuel Richardson em 1817.

\section{Pierre Constant Dalbin}

Segundo Neves ${ }^{109}$, Pierre Constant Dalbin era francês, natural de Versalhes, e chegou ao Rio de Janeiro em 1816. Possuía uma casa de livros na Rua Direita, n 9 e era também editor. Em 1820, Pierre Constant Dalbin remete uma extensa lista de livros a serem liberados pela Mesa do Desembargo. Entre eles, a obra Pamela de Samuel Richardson.

Alguns requerentes de romances ingleses não foram encontrados em anúncios e nem em fontes historiográficas pesquisadas. Tais requerentes foram: Bento Swenbergh, José Hobson e Robert Hill.

\footnotetext{
${ }^{109}$ NEVES, Lucia Maria Bastos P das. "Livreiros franceses no Rio de Janeiro: 1799 - 1824" in http://www.portcom.intercom.org.br/pdfs/bb3aea30006796253008218e5bdda0c1.pdf. Ultimo acesso: setembro de 2013.
} 


\subsubsection{O que se lia: do Rio de Janeiro para outras regiões}

Analisando as pequenas biografias dos requerentes de romances ingleses da Mesa do Desembargo do Paço, podemos observar a flutuação do número de pedidos entre 1810 e $1824^{110}$. O conhecimento destas obras e de seus requerentes nos permite concluir que não havia só o interesse em negociar os livros, já que muitos títulos são para uso próprio.

As profissões dos requerentes de origem de diversos países podem nos levar a esboçar a que mãos os romances ingleses chegavam. Sejam eles negociantes interessados em lucrar com a venda dos livros, sejam funcionários do Rei a se transferirem para outras regiões, os responsáveis pela importação de obras vindas de Portugal, França e Inglaterra comprovam que os romances atravessaram o oceano e aportaram no Rio de Janeiro.

Podemos perceber a preferência por obras de Maria Edgeworth, Daniel Defoe, Fielding, Walter Scott, Laurence Sterne e Samuel Richardson e Jonathan Swift. Obras de Jane Austen, Jane Porter, Ann Radcliffe e Mary Shelley foram também citadas, porém em documentos de requerentes que pediam a liberação de suas bibliotecas particulares. Nas próximas páginas, resumo quais foram as obras citadas destes autores por profissionais de importação e/ou de livreiros. A escolha destas obras pode ser atribuída ao gosto europeu no final do século XVIII e início do XIX.

\section{Maria Edgeworth}

Maria Edgeworth (1768 - 1849) foi uma das primeiras escritoras de literatura infantil realista na Europa. Escreveu também artigos variados sobre educação, língua e cultura, cartas, biografias e romances. Os periódicos Edimburgh e Quarterly Review sublinharam a importância da sua obra. Edgeworth foi também aclamada nos Estados Unidos como uma autora que desafiou o domínio masculino da literatura. ${ }^{111}$ Conhecida pela obra de cunho

\footnotetext{
${ }^{110}$ É importante ressaltar o estado de conservação desta documentação, sendo que o número preciso destes pedidos e obras pode ser prejudicado.

${ }^{111}$ BERMINGHAM. Ann. Consumption of Culture: 1600 - 1800. Image, Object, Text. New York: Routledge, 1997, p. 11.
} 
didático, Edgeworth teve vasta produção, já que começou a escrever na adolescência e publicou até o ano de sua morte, aos 81 anos.

As obras de ficção requisitadas de Maria Edgeworth foram Emilie de Coulanges, Essay on Irish Bulls, Harrington, Madame de Fleury, Moral Tales, Popular Tales, Scenes de la vie du grand monde, Sidney, The absentee, The modern Griselda e Vivian. O livro Tales of Fashionable life contém vários volumes com contos e histórias como Ennui, Almeria, Madame de Fleury, The Dun e Manoeuvring. ${ }^{112}$ Tais obras circularam no Rio de Janeiro, porém é válido destacar que Jozé Bernardino de Sena planejava levar as obras Popular Moral Tales, The Modern Griselda ${ }^{113}$, Irish Bulls, Comic Dramas, Leonora, Harrington's Thoughts on Boxes para São Paulo.

Edgeworth era conhecida nos circuitos literários europeus, chegando, até mesmo, a se corresponder com Walter Scott. Porém, sua obra era criticada por ter conteúdo altamente didático e moralista, com algumas nuances de colonialismo. Levantamos a hipótese que este pode ter sido o motivo pelo qual os importadores de produtos europeus no Rio de Janeiro apostavam na venda de suas obras: pela aceitação dos conceitos nos livros e pela facilidade com que as suas obras passariam pelo crivo da Alfândega.

\section{Daniel Defoe}

O segundo autor mais requisitado foi Daniel Defoe com a obra Robinson Crusoe. Daniel Defoe (1660 - 1731) foi jornalista e editor do jornal The Review, comerciante e escritor. Uma das características marcantes da obra Robinson Crusoe é a de descrever o enredo como acontecimentos verídicos. O autor da obra enfatiza a característica quando assina como editor e não como autor do livro. Esta obra foi requerida por Ambrozio Bourdon, Carlos Durand, Claudio João Baptista Loyseleur, Domingos Joze de Araujo Basto, Francisco Ignacio de

\footnotetext{
112 Estas obras de Maria Edgeworth podem ser consultadas por meio do site www.archive.org que oferece 9 volumes digitalizados.
}

${ }^{113} \mathrm{Na}$ lista de despachos, este romance é escrito como Grisalda. 
Souza Queiroz, Florencio Alb. de Macedo Pereira, Jeronimo Gonçalvez Guimarães, Joaquim Pereira de Almeida e Comp., Joze de la Brosse e Manoel Antonio da Silva Serva. Estes requerentes pretendiam também levar a obra para Porto Alegre, Bahia e São Paulo. Podemos presumir a popularidade destas obras devido ao interesse dos leitores europeus que habitavam no Rio de Janeiro.

\section{Walter Scott}

As obras de Walter Scott solicitadas pelos requerentes foram: Guy Mannering, Minstrelsy of the Scottish Border, Rob Roy, Tales of my Landlord, The Lay of the Last Minstrel: a Poem, The Lord of the Isles: A Poem, The Vision of Don Roderick: A Poem e Waverley. Considerei somente as obras de prosa de fiç̧ão Guy Mannering, Rob Roy, Tales of my Landlord e Waverley para os dados abaixo representados no gráfico. Os responsáveis pela importação das obras de Walter Scott foram: a empresa de Jorge Brittan, de Lozan Vial e Cia e Joze Bernardino de Sena, sendo que o último gostaria de enviá-las para São Paulo para uso próprio.

\section{Laurence Sterne}

Os requerentes interessados nas obras de Laurence Sterne importavam obras como A Sentimental Journey Through France and Italy, The Life and Opinions of Tristram Shandy e Beauties of Sterne. As obras "Beauties of' são compilações dos melhores trabalhos de autores europeus. Este tipo de antologia oferecia excertos e narrativas segmentadas que poderiam ser citadas em outros contextos ${ }^{114}$. O seu sumário auxiliava o leitor a escolher o trecho que Ihe fosse mais útil por meio de uma divisão de acordo com o assunto.

\footnotetext{
114 SANT, Ann Jessie Van. Eighteeth-Century Sensibility and the Novel: The senses in social context. Cambridge: Cambridge University Press, 1993, p. 118.
} 

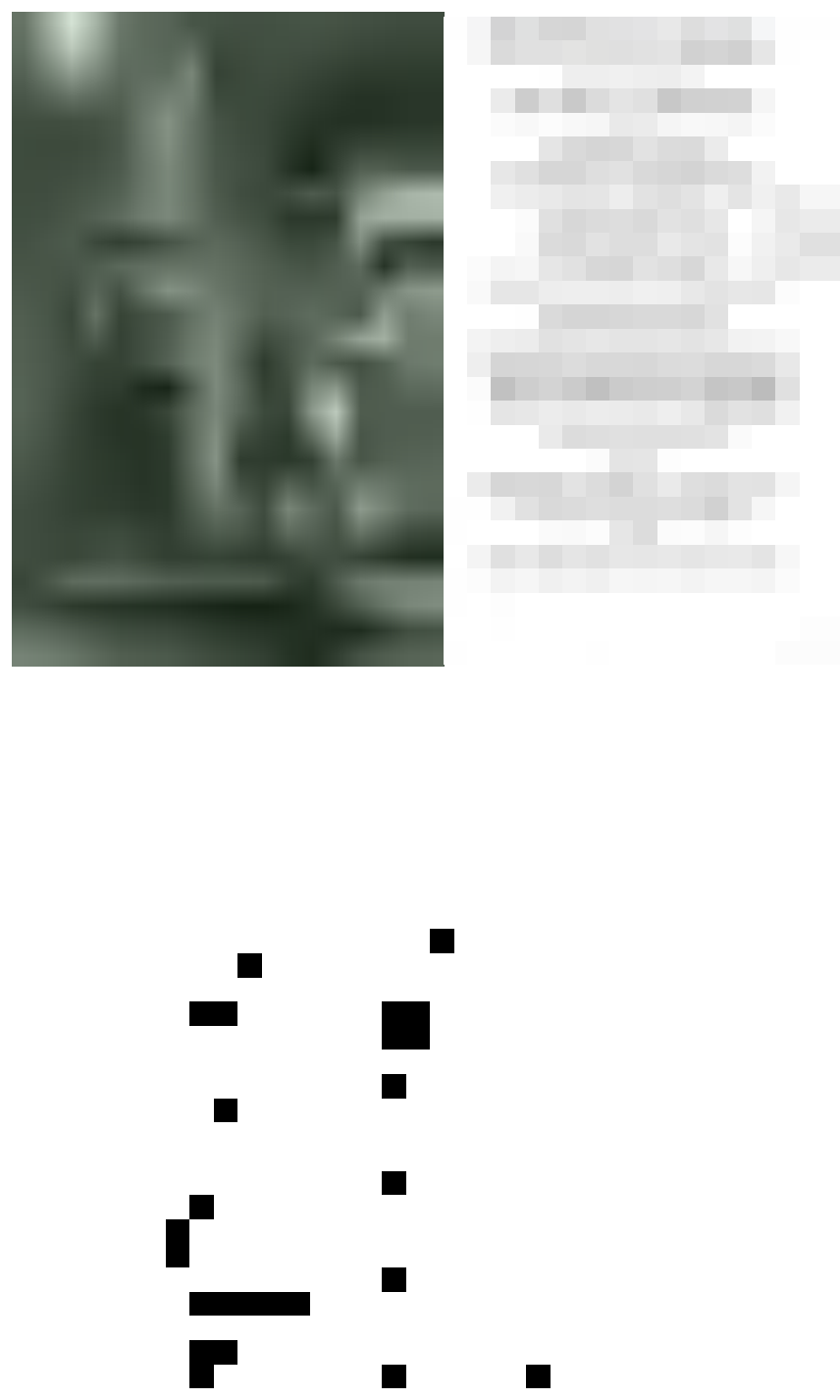

Primeira página do Sumário do Livro Beauties of Sterne; including many of his Letters and Sermons, all his Pathetic Tales, Humorous Descriptions and Most Distinguished Observations on Life. Selected for the heart of Sensibility, London, $1791^{115}$

A obra Tristram Shandy foi levada para São Paulo por Jozé Bernardino de Sena para uso próprio.

115 Este trecho é parte do exemplar online disponível no site: http://books.google.com.br/books?id=qPUdAAAAMAAJ\&dq=beauties+of+sterne\&printsec=front cover\&source=bl\&ots=zN5zSvFL0N\&sig=hnnZQqid2yh2eyFGIEaaf7xtUgQ\&hl=ptBR\&ei=_hQ2S7bdL8qPtgeoyaGCCQ\&sa=X\&oi=book_result\&ct=result\&resnum=1\&ved $=0 C A g Q$ 6AEwAA\#v=onepage\&q=\&f=false Acesso 01 de agosto 2012 . 


\section{Samuel Richardson}

De acordo com os documentos da Alfândega analisados, duas obras do autor Samuel Richardson chegaram ao Rio de Janeiro: os romances epistolares Pamela e The History of Sir Charles Grandison. Os responsáveis pelos requerimentos foram Joze Borges de Pinho em 1815, Ambrozio Bourdon e Domingos Joze de Araujo Basto em 1816 para Porto Alegre, Daniel Pedro Muller trazendo para São Paulo a obra Pamela em alemão em 1817 e Joze Bernardino de Sena em 1819. 
Podemos apontar como conclusão deste capítulo quais os romances que aportaram no Rio de Janeiro nas primeiras décadas oitocentistas. Foi possível distinguir três grupos distintos de importadores de obras: os que as procuravam para suas bibliotecas particulares, as firmas que importavam produtos variados, inclusive romances ingleses, e um terceiro grupo de livreiros. Dos vinte e quatro requerentes apontados por mencionarem romances ingleses nas listas para censores, $50 \%$ alegavam motivos pessoais para trazer suas bibliotecas particulares. Sete requerentes pertenciam ao segundo grupo: eram firmas comerciais especializadas em importação de artigos diversos: fazendas, vinhos, alimentos e livros. Três dos sócios destas firmas eram especializados em leilões: Ambrozio Bourdon, Jorge Brittain e Jozé de la Brosse. Somente três requerentes são listados como comerciantes de livreiros, sendo que um deles, Silva Serva, levaria os livros para a Bahia.

No capítulo a seguir, analisaremos os anúncios da Gazeta do Rio de Janeiro e Diário do Rio de Janeiro para verificar se os autores citados nas listas de liberação de livros eram também encontrados nas livrarias e lojas não especializadas. 


\section{Capítulo 2}

\subsection{Romances ingleses no comércio fluminense}

No capítulo anterior, constatamos por meio da análise dos documentos da Mesa do Desembargo do Paço que o Rio de Janeiro era um centro de reverberação do comércio de romances no início do século XIX. Do Rio de Janeiro, os romances seriam enviados para Rio Grande do Sul, São Paulo e Bahia. Proponho explorar nas páginas seguintes os possíveis caminhos que estas obras tomaram no território fluminense.

Os comerciantes de diversas áreas estavam empenhados em vender livros estrangeiros no Rio de Janeiro oitocentista, aproveitando a voga das outras novidades europeias oferecidas ao público fluminense. Sabemos também que o comércio de livros não se restringia somente ao grupo de livreiros, sendo que negociantes de produtos variados tais como escravos, tecidos, porcelanas e móveis anunciavam também livros nos periódicos.

Os comerciantes instalados no Rio de Janeiro eram sobretudo ingleses, franceses e portugueses. Os negociantes portugueses ocupavam postos administrativos importantes e cargos na Junta do comércio e lidavam com o comércio de grosso trato ${ }^{116}$. Os ingleses diferenciavam-se dos franceses, que preferiam as ruas mais estreitas para suas lojas de luxo que ofereciam jóias, licores e objetos da moda. Os comerciantes franceses eram conhecidos por suas casas de moda e vestuário, perfumarias e confeitarias. Os negociantes franceses escolheram as ruas dos Ourives e do Ouvidor para suas pequenas lojas, com mostruários variados, cortinas e espelhos ${ }^{117}$. As histórias interessantes sobre algumas destas casas contadas por

\footnotetext{
116 "Negociantes de grosso trato são aqueles que empregam grandes fundos em tráficos e manufaturas... São aqueles que fazem comércio da especulação, bancos e seguros." In: LISBOA, José da Silva. Princípios de direito mercantil e leis da Marinha. Lisboa: Impressão Régia, 1819, tratado V, p. 69.
}

117 CRULS, G. Aparência do Rio de Janeiro. Rio de Janeiro: Livraria José Olympio Editora, 1952. p. 245. 
Joaquim Manuel de Macedo em seu livro Memórias da Rua do Ouvidor ${ }^{118}$ me auxiliaram a entender como o comércio começava a florescer na cidade fluminense.

Outra fonte de igual importância foi a obra de Gilberto Freyre que ajudou a compreender a extensão da influência dos ingleses no comércio do Rio de Janeiro. Em seu livro Ingleses no Brasli ${ }^{119}$, Freyre demonstra como os ingleses foram pioneiros no Brasil em diversas áreas: nas primeiras fundições modernas, no primeiro cabo submarino, nas primeiras estradas de ferro, nos primeiros telégrafos, nos primeiros bondes, na primeira iluminação a gás, nos primeiros barcos a vapor, nas primeiras redes de esgotos ${ }^{120}$. Foram os ingleses os responsáveis pela iniciativa e pelas técnicas modernas empregadas nestas obras.

Os homens de negócios da Inglaterra estabeleceram-se em diferentes cidades do Brasil, trazendo consigo livros, outrora proibidos pela Inquisição ou pelos padres menos liberais. Eram atacadistas e tinham armazéns. De acordo com Gilberto Freyre, a área predileta destes ingleses compreendia as Ruas Direita, Alfândega e dos Pescadores, mas há também evidências da existência de algumas lojas na Rua do Ouvidor.

Estes negociantes instalados nas principais ruas do Rio de Janeiro utilizavam os anúncios nos periódicos como meio de propaganda dos seus produtos. Estratégias para chamar a atenção do leitor e atrair mais compradores são usadas pelos editores. Os produtos trazidos por negociantes estrangeiros vindos de Portugal, França e Inglaterra anunciados na Gazeta do Rio de Janeiro ${ }^{121}$ e no Diário do Rio de Janeiro ${ }^{122}$

118 MACEDO, J. M. de. Memórias da Rua do Ouvidor. Brasília: Editora Universidade de Brasília, 1988.

${ }^{119}$ FREYRE, G. Ingleses no Brasil: Aspectos da influência britânica sobre a vida, a paisagem e a cultura do Brasil. Rio de Janeiro: Topbooks, 2000.

${ }^{120}$ Idem, p. 62.

121 Os anúncios da Gazeta do Rio de Janeiro analisados datam de 1808 a 1821. Os erros tipográficos e ortográficos foram transcritos aqui como encontrados nos anúncios do jornal.

${ }^{122}$ Foram considerados anúncios publicados nos exemplares do Diário do Rio de Janeiro de 1821 a 1831. 
nas primeiras décadas do século XIX são oferecidos "A preços commodos" e descritos como de "pouco uso" ou "de bom gosto".

Neste capítulo, apresento um estudo sobre as fontes utilizadas para localizar os negociantes que ofereciam romances ingleses nas duas primeiras décadas oitocentistas no Rio de Janeiro: os periódicos Gazeta do Rio de Janeiro e Diário do Rio de Janeiro. Foi necessário entender qual papel estes dois jornais exerciam na sociedade de corte para melhor inferir quem era o possível público que anunciava e procurava por romances ingleses, bem como qual a importância da região onde concentravam-se as lojas.

Carlos Rizzini nos auxilia a entender quais os papéis dos dois periódicos pesquisados em seu O Livro, o Jornal e a Tipografia ${ }^{123}$, um estudo geral sobre a circulação da informação e sobre o jornalismo no Brasil.

A obra de Maria Beatriz Nizza da Silva ajudou a situar a Gazeta do Rio de Janeiro no contexto. Ela mostra como as informações contidas neste periódico podem fornecer um estudo aprofundado do cotidiano fluminense. Esta obra é abrangente, pois lida com aspectos diversos sobre a vida no Rio de Janeiro de 1808 a 1822, tais como moradia, alimentação, festas, saúde, vida cultural, profissionais e comércio. Interessa-nos concentrar no último tópico, em especial, o comércio de romances ingleses. ${ }^{124}$

A obra de Nelson Werneck Sodré História da Imprensa no Brasil ${ }^{125}$ nos auxiliou a entender a influência ou ausência proposital de influência política dos periódicos no contexto fluminense.

${ }^{123}$ RIZZINI, Carlos. O livro, o jornal e a tipografia no Brasil, 1500-1822: com um breve estudo geral sobre a informação. - Ed. fac-similar. - São Paulo: Imprensa Oficial do Estado, 1988.

124 SILVA, Maria Beatriz Nizza da. A Gazeta do Rio de Janeiro (1808 - 1822): Cultura e Sociedade. Rio de Janeiro: EdUERJ, 2007.

${ }^{125}$ SODRÉ, Nelson Werneck. História da imprensa no Brasil. Rio de Janeiro: Mauad, 1999. 
A obra fundamental consultada foi O livro no Brasil ${ }^{126}$. Hallewell oferece um estudo pioneiro sobre a história do livro e das livrarias no país. Nesta obra encontramos alguns dos negociantes citados nesta dissertação.

A obra de Ubiratan Machado publicada recentemente, História da Livrarias Cariocas ${ }^{127}$, acompanha cerca de três séculos e meio de comércio livreiro, sendo que seus primeiros capítulos auxiliaram a entender quem eram os negociantes especializados em livros.

Esperamos nas próximas páginas apresentar um estudo que tem como objetivo considerar os negociantes especializados ou não que vendiam romances ingleses e os anunciaram os romances ingleses nos periódicos Gazeta do Rio de Janeiro e Diário do Rio de Janeiro.

${ }^{126}$ HALLEWELL, Laurence. O Livro no Brasil: sua história, São Paulo: EdUSP. 2005.

${ }^{127}$ MACHADO, Ubiratan Machado. História das livrarias cariocas. São Paulo: Edusp, 2012. 


\subsection{Periódicos}

"Porque os anúncios desses jornais velhos (..) nos transmitem informações sobre o lado mais profundamente humano do passado brasileiro" Gilberto Freyre

O Rio de Janeiro veio a conhecer a tipografia em 1808, como escreve Hipólito da Costa em seu periódico Correio Brasiliense:

Saiba o mundo, e a posteridade, que, no ano de 1808 da era cristã, mandou o governo português, no Brasil, buscar à Inglaterra uma impressão com os seus apendículos necessários, e a remessa que daqui se Ihe fez importou em cem libras esterlinas!!! Com tudo diz-s, que se augmentará este estabelecimento, tanto mais necessário, quanto o Governo ali, nem pode imprimir as suas Ordens para lhes dar suficiente publicidade. $^{128}$

Trazidos por Antonio de Araújo, futuro conde da Barca, nos porões da nau Meduza, os prelos possibilitaram o começo da história da tipografia no Brasil. Logo após o Decreto da criação da tipografia, foi criada uma Junta Administrativa e, em 27 de setembro, uma junta composta para analisar os conteúdos a serem impressos na Impressão Régia foi constituída. Esta junta era composta pelos letrados José Bernardes de Castro, oficial da Secretaria de Estrangeiros e da Guerra, Mariano da Fonseca e José da Silva Lisboa. Pouco tempo depois, a Mesa do Desembargo do Paço assumiu o controle dos "papéis e livros" que pudessem ser "contra a religião, a moral e os bons costumes." 129

Em poucos anos de atividades - de 1808 a 1822 -, a Impressão Régia publicou tal variedade de títulos que Mindlin interpreta este fenômeno como uma "grande curiosidade intelectual e fervilhamento de interesses diversos" ${ }^{130}$. Um dos primeiros estudiosos a catalogar as obras impressas pela Impressão

${ }^{128}$ Correio Brasiliens.Junho de 1808, p. 394.

${ }^{129}$ Aviso da Impressão Régia de 24 de junho de 1808.

130 MINDLIN, José E. Apresentação in: CAMARGO, Ana Maria de Almeida \& MORAES, Rubens Borba. Bibliografia da Impressão Régia. São Paulo: EDUSP, Livraria Kosmos Editora, 1993. Vol. 1, p. XI. 
Régia no Rio de Janeiro foi Alfredo do Valle Cabral em Annaes da Imprensa Nacional ${ }^{131}$. Valle Cabral coletou 1243 referências bibliográficas de publicações. Em 1977, Maria Beatriz Nizza da Silva investigou os apontamentos de Valle Cabral e afirmou que quatro eram as obras de fiç̧ão publicadas pela Impressão: O castigo da prostituição; As duas desafortunadas; Historia da donzella Theodora e Triste effeito de huma infidelidade ${ }^{132}$. Em 1993, Rubens Borba de Moraes e Ana Maria de Almeida Camargo publicaram a Bibliografia da Impressão Régia e ampliaram para 1429 o número de títulos impressos, dentre eles, outras obras de ficção foram adicionadas: Diabo Coxo, A Filosofa por Amor, A Choupana India, Paulo e Virgínia, Carta de Heloise e Abelardo, O amor ofendido e vingado, A Má Mãi e o primeiro livro para crianças publicado no Brasil, Leitura para os Meninos. ${ }^{133}$ A história editorial dos livros impressos pela Impressão Régia também foi investigada por Simone Cristina Souza. ${ }^{134}$

Como se pode verificar nas listas acima, não encontramos romances ingleses publicados pela Impressão Régia. Porém, é importante ressaltar que esta tipografia permitiu a impressão do periódico Gazeta do Rio de Janeiro, cujos anúncios evidenciam a procura e oferta de romances ingleses, inclusive na própria loja da Gazeta.

Para melhor visualização e levando em consideração que os periódicos foram publicados em períodos diferentes e possuíam formatos e seções distintas, separei a descrição dos dados e a análise cronológica em dois grupos

${ }^{131}$ CABRAL, Alfredo do Valle. Annaes da Imprensa Nacional do Rio de Janeiro 1808 a 1822. Rio de Janeiro: Imprensa Nacional, 1881.

132 SILVA, Maria Beatriz Nizza da. Cultura e Sociedade no Rio de Janeiro (1808-1821). São Paulo, SP: Com. Ed. Nacional, 1977. p. 197-214.

${ }^{133}$ CAMARGO, Ana Maria de Almeida \& MORAES, Rubens Borba. Bibliografia da Impressão Régia. São Paulo: EDUSP, Livraria Kosmos Editora, 1993. Vol. 1, p. XI.

134 SOUZA, Simone Cristina Mendonça de. Primeiras impressões: romances publicados pela Impressão Régia do Rio de Janeiro (1808-1822). Tese apresentada ao Instituto de Estudos da Linguagem, da Universidade Estadual de Campinas para obtenção do título de Doutor

em Teoria e História Literária. 2007. 
principais. Primeiramente, investigarei os anúncios da Gazeta do Rio de Janeiro e, em seguida, os do Diário do Rio de Janeiro. 
2.2.1 A Gazeta do Rio de Janeiro ${ }^{135}$

A Gazeta do Rio de Janeiro foi publicada pela primeira vez em setembro de 1808 pela Impressão Régia do Rio de Janeiro. Seguiu a dimensão padrão dos periódicos estrangeiros $(19 \times 13,5)$, com formato in-quarto, assim como a estrutura da Gazeta de Lisboa. Na epígrafe da Gazeta do Rio de Janeiro, os editores publicavam as palavras de Horácio em latim, que podem ser traduzidas em português como: "A

${ }^{135}$ Os exemplares da Gazeta do Rio de Janeiro de 1808 a 1822 foram consultados no acervo de microfilmes da Faculdade de Filosofia, Letras e Ciências Humanas da Universidade de São Paulo. Recentemente, foram disponibilizados no site da Fundação Biblioteca Nacional Digital:

http://objdigital.bn.br/acervo_digital/div_periodicos/gazeta_rj/gazeta.htm 
doutrina promove a força inata e os cultos corretos fortalecem os peitos." ${ }^{136} \mathrm{Sem}$ grandes atrativos, ela servia ao propósito de oferecer algumas notícias sobre os príncipes europeus, documentos oficiais, seção de avisos com anúncios de vendas e notícias marítimas. Teve como editores o Frei Tibúrcio José da Rocha, Manuel Ferreira de Araújo Guimarães e Francisco Vieira Goulart. Inicialmente, o periódico era publicado aos sábados, contando também com edições especiais às quartas-feiras, chamadas Gazeta Extraordinária do Rio de Janeiro ${ }^{137}$. O editor explica que os números da Gazeta Extraordinária do Rio de Janeiro eram publicados quando "houverem notícias tão interessantes que se julgue a propósito comunicallas ao Publico antes do Sabbado." ${ }^{138}$ No primeiro exemplar, notícias de Londres, Sevilha e Porto são oferecidas, bem como uma proclamação e um recado de ânimo aos portugueses em Lisboa. A Gazeta Extraordinária se tornaria mais freqüente nos meses seguintes, sendo publicada às segundas-feiras, às terças-feiras e às sextas-feiras. $A$ partir de $1^{\circ}$ de julho de 1817, a Gazeta do Rio de Janeiro passou a cobrar 200 réis por linha do anúncio para assegurar a brevidade.

A Gazeta era estruturada em duas partes: seção noticiosa e seção de avisos. $\mathrm{Na}$ seção noticiosa, o periódico incluía artigos diversos de jornais da Europa e apresentava cartas de políticos, além de descrever o cotidiano da realeza, como distribuição de títulos de nobreza e as datas importantes para a Corte. Na seção de avisos, encontramos os anúncios de venda, aluguel, leilões e prestação de serviços.

Considerado por Hipólito da Costa um periódico mesquinho por imprimir "matéria tão ruim" em "tão boa qualidade de papel", a Gazeta do Rio de Janeiro se transformou e, em 1817, publicou uma seção intitulada "notícias literárias" onde assuntos como mineralogia e geografia eram discutidos.

E ao longo dos anos de publicação, das mudanças pelas quais passou, a Gazeta do Rio de Janeiro nos fornece material inestimável com relação à circulação de romances no Rio de Janeiro. É por meio de seus anúncios que localizamos os primeiros livreiros na cidade e conseguimos apontar as obras mais citadas. Exemplo

\footnotetext{
${ }^{136}$ SEMERARO, Cláudia Marina (org.) História da Tipografia no Brasil. São Paulo, SP: Museu de Arte de São Paulo/ Secretaria de Cultura, Ciências e Tecnologia do Governo do Estado de São Paulo, 1979.

137 SILVA, Maria Beatriz Nizza da. A Gazeta do Rio de Janeiro (1808 - 1822): Cultura e Sociedade. Rio de Janeiro: edUERJ, 2007. p. 10.

${ }^{138}$ Gazeta do Rio de Janeiro, 14 de setembro de 1808.
} 
disso é o anúncio de 15 de outubro de 1817. Uma nota sobre a morte de Madame de Staël foi veiculada, mostrando o possível interesse do público leitor em relação às obras desta autora.

Ao avaliar o número de anúncios de comerciantes de livros na Gazeta do Rio de Janeiro, pode-se constatar a importância para a população fluminense destas "cazas de livros" e das casas não especializadas. Os comerciantes que faziam pedidos de liberação de livros são os mesmos que anunciam "quinquilherias", fazendas, papéis brancos, escravos e livros. Podemos perceber esta tendência pelo exemplo do livreiro Carlos Durand, que também se dedicava ao comércio de vestimentas:

"Acha-se em caza de Carlos Durand, e Ca., na rua do Ouvidor N. 28 no primeiro andar, hum sortimento de prata, composto de huma manteigueira e seu prato, quatro almoços e seus pratos, dois azeiteiros e vinagreiros, hum assucareiro, quatro saleiros, quatro vazos para pimenta e duas mustardeiras, hum grande jarro para agua, lavrado tudo de bom gosto, e mais hum par de serpentinas de bronze dourado, leques de todas as qualidades, muzica a 50 por 100 a baixo do preço de Paris, chales fingindo lã de camello de muito bom gosto - Livros, Vida e obras dos Pintores os mais celebres de todas as escolas, contendo 475 estampas, $8 \mathrm{vol}$. em $4^{\circ}$. Obras completas de Poussin, com 170 estampas, $3 \mathrm{vol}$ em $4^{\circ}$. Atlas Maritimos das quatro partes do Mundo, 375 mapas, 5 vol. em $4^{\circ}$ e outros atras. Galeria dos Chefes de obra d'Architectura, Pintura e Escultura, 1 vol. Em folio. Bibliotheca Universal das viagens, 6 vol. em $8^{\circ}$ Arte de embranquecer os panos de linhos, fios, e algodões, 1 vol. Descripção de Paris e de seus edificios, 2 vol. em $8^{\circ}$ Galeria dos Pintores Flamengos, 3 vol. folio, 101 estampas. Historia de França, depois de 1789, com mapas e estampas 7 vol. em $8^{\circ}$. Descripção das medalhas Chinezas, hum Diccionario Chinez e Francez, Relação das cerimonias religiozas e militares da coroação de Bonaparte, $1 \mathrm{vol}$. Museu Francez com gravuras arranjadas por obras dos maiores mestres, $10 \mathrm{vol}$. em $8^{\circ}$. Obras completas de Bernqui, $28 \mathrm{vol}$ em 18. Quadro historico da revolução Franceza, 3 vol. em $4^{\circ} \mathrm{com}$ mapas e atlas iluminados." Gazeta do Rio de Janeiro -22 de janeiro de 1817. 
As obras tornavam-se atrativas por meio de recursos de propaganda usados pelos anunciantes.

"a novella intitulada a filosofa por amor, ou cartas de dois amantes apaixonados e virtuosos 2 vol,. por 1910 reis, que tem merecido geral aceitacão em todos os idiomas. Vende se na loja de Paulo Martin, filho, aonde se achão historia de dois amantes, por 960 reis. Paulo e Virginia 2 vol, por 1600 reis - choupana índia, por 640 reis - diabo coxo, 2 vol., por 1600 reis." Gazeta do Rio de Janeiro - 21 de março de 1812 (grifo nosso)

Este comentário sobre a "geral aceitação em todos os idiomas" é também uma maneira de impressionar o leitor do jornal. A importância da variedade de idiomas das obras oferecidas é recorrente. Obras em francês e inglês são valorizadas nos anúncios.

Outra técnica de publicidade é ressaltar o sucesso que a obra teria feito na Europa, como se pode notar no anúncio da obra de Chateaubriand vendida na loja da Gazeta.

\begin{tabular}{l} 
"Na loja da gazeta se acha a mui moderna obra impressa em \\
Londres em 1814. - De Bonaparte e dos Bourbons, e da \\
necessidade de nos unir-mos aos nossos legítimos \\
príncipes, para a felicidade da franca e da Europa, por F. A, \\
Chauteaubriand, traduzido em portuguez, 1 vol, $8^{\circ}$ por 960 \\
reis. Para mostrar decedidamente o elogio dessa produção, \\
bastará dizer que no decurso de alguns mezes, se venderão \\
\hline cincoenta e tantos mil exemplares em Paris." Gazeta do Rio \\
de Janeiro - 14 de setembro de 1816 (grifo nosso)
\end{tabular}

Estas técnicas de propaganda eram utilizadas não somente para anunciar livros, mas produtos em geral. Os anúncios contam constantemente com palavras como "ultimo gosto", produtos que haviam chegado "proximamente", "ultimamente" ou "novamente". Estas descrições sugeriam aquilo de mais novo produzido na Europa, principalmente na França e na Inglaterra. 
“...a preços commodos”

Interessa-nos apontar os romances ingleses encontrados nos anúncios de venda, compra e aluguel na Gazeta do Rio de Janeiro.

O leitor poderia encontrar a obra Pamela, or Virtue Rewarded, de Samuel Richardson, até 1814, na loja de Manoel Mandillo e José Borges de Pinha. Foi neste ano que os dois livreiros se associaram. De acordo com Luís Joaquim dos Santos Marrocos, funcionário da Biblioteca Real, a loja de Manoel Mandillo era uma das três mais conhecidas e freqüentadas do Rio de Janeiro, assim como as de Manoel Joaquim da Silva Porto (Rua da Quitanda, na esquina da R. de S. Pedro) e Francisco Luís Saturnino da Veiga (defronte da capella dos terceiros de N. S. do Carmo). ${ }^{139}$

Nos anúncios dos anos posteriores, as obras citadas poderiam ser encontradas na loja da Gazeta, responsável pela grande parte dos anúncios de venda de livros no periódico.

Em 1816, a loja da Gazeta oferecia o título Luíza, ou o Casal no Bosque. A primeira edição de Louisa; or The Cottage on the Moor de Elizabeth Helme foi publicada por um editor em Londres em 1787. Helme, que já havia traduzido diversos livros de viagem, alcançou o reconhecimento com a publicação deste primeiro romance. Helme é uma autora inglesa de romances que publicou diversas obras como Albert: or, the Wilds of Strathnavern (1799) e St Clair of the Isles: or, The Outlaws of Barra, A Scottish Tradition (1803).

No ano seguinte, a mesma loja oferecia outros livros de ficção ingleses bem conhecidos na Europa: Tom Jones, Robinson Crusoé e Viagens de Guliver. O livro Viagens de Gulliver de Jonathan Swift também aporta no Rio de Janeiro e é oferecido em três volumes por apenas 2.880 réis. Para podermos comparar os preços, basta lembrar que no mesmo anúncio encontra-se o valor

${ }^{139}$ Cartas de Luís Joaquim dos Santos Marrocos, escritas no Rio de Janeiro a sua família em Lisboa, de 1811 a 1821. Anais da Biblioteca Nacional do Rio de Janeiro. Rio de Janeiro: Imprensa Nacional, vol. LVI, 1939, p. 295. 
de um volume da obra Irma ou as desgraças de huma jovem Orphã por 1200 réis ou que no mesmo ano o armazém da Rua da Alfândega $N^{\circ} 5$ vendia uma medida de cerca de meio quilo de chá por 1400 réis. ${ }^{140}$

No armazém da rua d'Alfandega $N$. 5, ha á venda chá
superior vindo no Navio Robusto: a saber, uxim 800 réis, isso
960, perola e aljôfar 1400 o arratel, e o vindo nos outros
Navios este mesmo anno uxim 700 réis, isson 800 , perola e
aljôfar 1200, e em caixa com 10 por cento de abatimento.
lgualmente se continua a vender no mesmo armazém, a
miúdo e atacado, louça da China e Ingleza, cristaes e vidros,
assim como toda a qualidade de fazendas e miudezas da
China."- Gazeta do Rio de Janeiro, 2 de agosto de 1817 .

Por fim, o livro oferecido em 1820, também na loja da Gazeta, é a História da Infeliz Clara Harlowe, como se pode observar abaixo:

Na loja da gazeta se acha o complemento da historia da infeliz
clara Harlowe, que são 8 volumes, desde tomo 7 a 15 a 960
reis cada volume, e se vendem separados, e toda obra por 12
800. - Gazeta do Rio de Janeiro - 03 de março de 1820

O editor deseja interessar o leitor na obra, apelando para o fato de que, se o cliente não tivesse condições financeiras de comprar a obra inteira, poderia adquiri-la em volumes separados.

Apresento uma tabela a seguir que mostra o número de anúncios de estabelecimentos comerciais onde romances ingleses poderiam ser comprados, vendidos ou, em alguns casos, alugados.

\footnotetext{
${ }^{140}$ Gazeta do Rio de Janeiro. 02 de agosto de 1817.
} 


\begin{tabular}{|l|l|l|l|}
\hline Ano & Autor & Obra & $\begin{array}{l}\text { Número de vezes } \\
\text { em que o mesmo } \\
\text { anúncio é repetido }\end{array}$ \\
\hline 1814 & Samuel Richardson & Pamela em $8^{\circ} 2$ vol. & 1 \\
\hline 1816 & Elizabeth Helme & $\begin{array}{l}\text { Luiza ou o cazal no } \\
\text { bosque }\end{array}$ & 1 \\
\hline 1817 & Henry Fielding & Tom Jones & 1 \\
\cline { 2 - 4 } & Daniel Defoe & $\begin{array}{l}\text { Vida e Aventuras } \\
\text { Admiraveis } \\
\text { Robinson Crossué }\end{array}$ & 1 \\
\cline { 2 - 4 } & Jonathan Swift & Viagens de Guliver & 1 \\
\hline 1820 & Samuel Richardson & História da Infeliz Clara & 1 \\
& & Harlowe & \\
\hline
\end{tabular}

Este interesse em oferecer romances ingleses se mostra evidente por meio da análise destes anúncios do início do século XIX. Interessa-nos expandir o escopo da pesquisa, já que o número de livrarias aumenta consideravelmente no Rio de Janeiro ao longo da década de 1820. Para tanto, pesquisamos então um segundo periódico de grande importância: o Diário do Rio de Janeiro. A descrição e análise dos anúncios nele encontrados é o objetivo das próximas páginas. 


\subsubsection{Diário do Rio de Janeiro ${ }^{141}$}

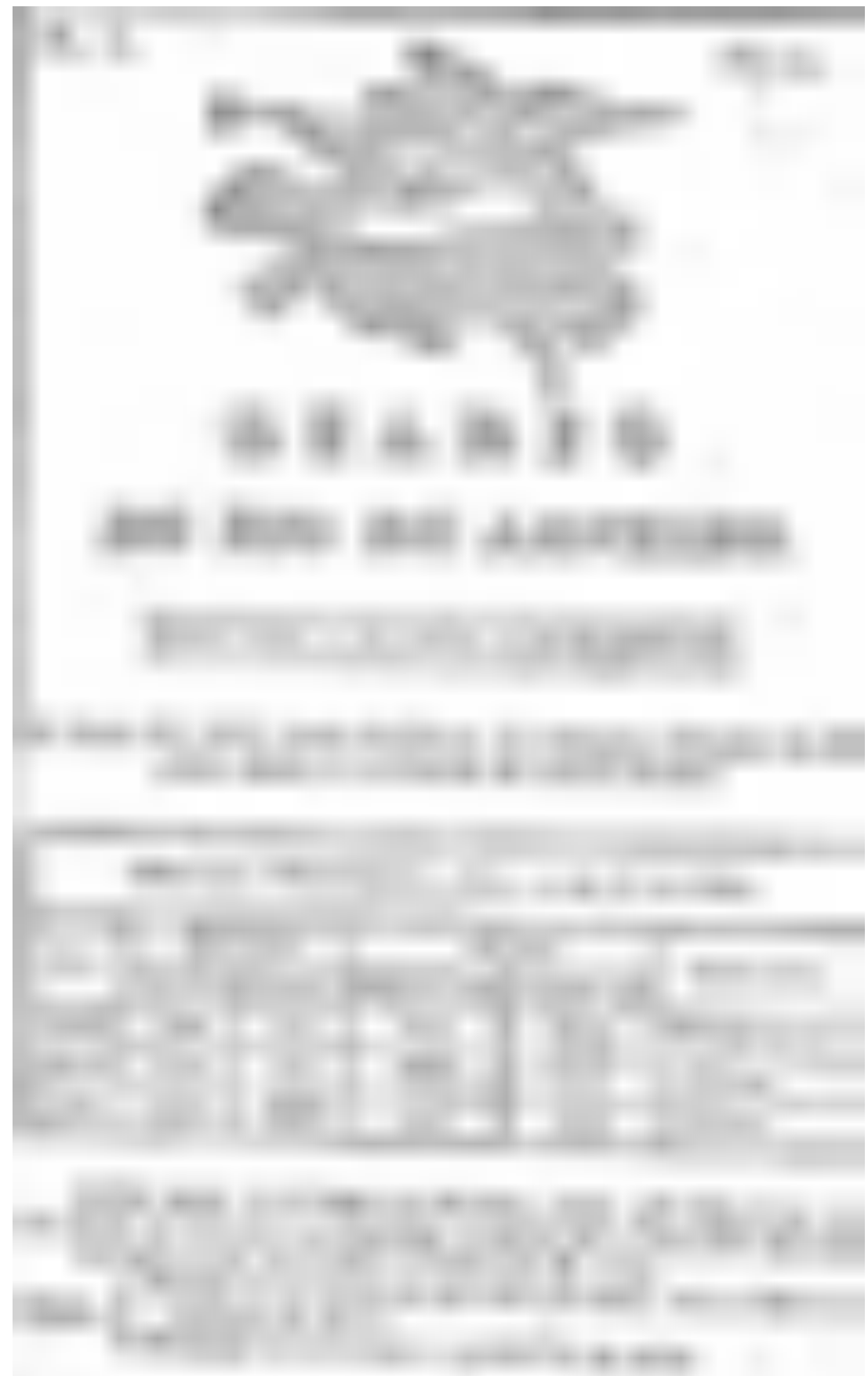

O Diário do Rio de Janeiro teve seu primeiro número lançado em junho de 1821. Fundado e redigido pelo português Zeferino Vito de Meireles e publicado pela Typografia Real, o Diário possuía uma edição diária. O Diário do Rio de Janeiro manteve-se distanciado de temas políticos e era constituído de

${ }^{141}$ Os exemplares do Diário do Rio de Janeiro de 1821 a 1831 foram consultados no acervo de microfilmes da Faculdade de Filosofia, Letras e Ciências Humanas. Recentemente foram disponibilizados no site da Fundação Biblioteca Nacional Digital:

http://hemerotecadigital.bn.br/acervo-digital/diario-rio-janeiro/094170 
seções como "observações metereológicas", "correios", "notícias particulares", "obras públicas", subscripções", "achados" e "vendas". Diferentemente da Gazeta do Rio de Janeiro, os seus anúncios eram publicados gratuitamente, como mostra o aviso do dia $1^{\circ}$ de junho de 1821 :

Neste Diário se insérem gratuitamente todos e quaesquer
Annuncios ou Noticias particulares, que convenhão, e seja lícito
imprimir (...)" - Diário do Rio de Janeiro - 01 de junho de 1821

Este periódico anunciava jornais que começariam a ser publicados, como o fez com relação ao Reverbero Constitucional Fluminense e ao Diário Constitucional em setembro de 1821. Folhetos literários eram anunciados com freqüência, como a Sabbatina Familiar.

O Diário do Rio de Janeiro oferecia a seção "LIVROS A'VENDA", diferenciando-se dos demais jornais publicados na época por esta especialização da publicação de anúncios.

O oferecimento ou procura de obras de ficção inglesas foi encontrado, em grande parte, em quatro seções: "livros a venda", "venda", "compra" e "leilões". Apesar de certos anúncios não fornecerem os nomes dos livros comercializados nem os nomes dos anunciantes, são úteis para a compreensão da circulação de obras. Por estes anúncios sabemos que o comércio livreiro era realizado por negociantes e leiloeiros de outros produtos, como no exemplo abaixo:

"Quem quizer comprar hum bom cavalo, alguns móveis com huma
boa Secretaria, commoda, estantes de Livros e Livros Francezes,
Inglezes e Portuguezes, dirija-se á rua de Santa Thereza defronte
do Regedor." Diário do Rio de Janeiro - 05 de junho de 1821

A importância destes anúncios de particulares anônimos vendendo ou procurando por volumes pode ser observada no período analisado. A título de ilustração, podemos citar o caso do anúncio abaixo, no qual uma viúva cobra o retorno de um tomo da obra religiosa de Wan Espen para que se possa fazer a venda. Pode-se supor que a pessoa que contraiu o empréstimo do livro seja um leitor do Diário do Rio de Janeiro. A mesma viúva faz o pedido novamente 
para que a obra seja devolvida após quatro meses da publicação do primeiro anúncio, declarando que "obra mutilada a ninguém aproveita" ${ }^{142}$.

“O falecido Doutor João Francisco Coelho emprestou o $1^{\circ}$ tomo
da obra de Wanespen; que até agora não foi entregue; qualquer
pessoa em cujo poder se achar fará o favor de o entregar á viúva
do mesmo falecido, a fim de que possa verificar a sua venda: ou
haja de declarar neste Diario a sua moradia, para se hir buscar o
dito livro". Diário do Rio de Janeiro - 01 de agosto de 1821

Anúncios de particulares, de livreiros e comerciantes em geral foram coletados e organizados na tabela a seguir que mostra o número de anúncios, bem como os autores das obras comercializadas cronologicamente.

\begin{tabular}{|c|c|c|c|c|}
\hline$\stackrel{\text { 운 }}{\frac{1}{2}}$ & 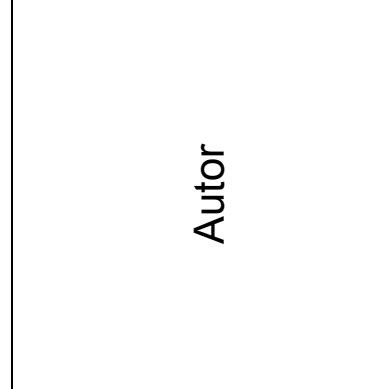 & 苋 & 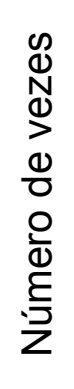 & 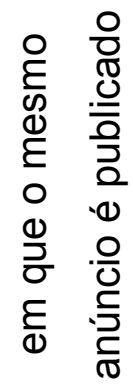 \\
\hline 1821 & Daniel Defoe & Robinson Crusoe & & 1 \\
\hline \multirow[t]{3}{*}{1823} & Jonathan Swift & Gulliver's travels & & 1 \\
\hline & Samuel Richardson & Pamela & & 1 \\
\hline & Laurence Sterne & Obras de Sterne & & 1 \\
\hline \multirow[t]{2}{*}{1824} & Daniel Defoe & Robinson Crusoe & & 1 \\
\hline & Henry Fielding & Tom Jones & & 1 \\
\hline
\end{tabular}

142 "A Viuva do Doutor João Francisco Coelho roga aquella pessoa, a quem seu marido empresta $01^{\circ}$ tomo de Wan Espen, queria restituilo; pois huma obra mutilada a ninguém aproveita." Diário do Rio de Janeiro - 10 de dezembro de 1821. 


\begin{tabular}{|c|c|c|c|}
\hline & Walter Scott & Obras de Walter Scott & 2 \\
\hline & Regina Maria Roche & Amanda e Oscar & 1 \\
\hline \multirow[t]{6}{*}{1825} & Daniel Defoe & Robinson Crusoe & 4 \\
\hline & Elizabeth Helme & Saint Clair das Ilhas & 4 \\
\hline & Walter Scott & Obras de Walter Scott & 4 \\
\hline & Jonathan Swift & Gulliver's travels & 2 \\
\hline & Ann Radcliffe & Obra de Ann Radcliffe & 1 \\
\hline & Samuel Richardson & Pamela & 2 \\
\hline \multirow[t]{4}{*}{1826} & Elizabeth Helme & Saint Clair das Ilhas & 1 \\
\hline & Jonathan Swift & Gulliver's travels & 1 \\
\hline & Walter Scott & Obras de Walter Scott & 2 \\
\hline & Samuel Richardson & Pamela & 2 \\
\hline \multirow[t]{7}{*}{1827} & Samuel Richardson & $\begin{array}{l}\text { Pamela; } \\
\text { História de Clara Harlowe }\end{array}$ & 2 \\
\hline & Jonathan Swift & Gulliver's travels & 1 \\
\hline & Regina Maria Roche & Amanda e Oscar & 1 \\
\hline & Henry Fielding & Tom Jones & 1 \\
\hline & Walter Scott & Obras de Walter Scott & 2 \\
\hline & Elizabeth Helme & Saint Clair das Ilhas & 2 \\
\hline & Daniel Defoe & Robinson Crusoe & 2 \\
\hline \multirow[t]{4}{*}{1828} & Samuel Richardson & História de Clara Harlowe & 1 \\
\hline & Regina Maria Roche & Amanda e Oscar & 1 \\
\hline & Jonathan Swift & Gulliver's travels & 1 \\
\hline & Elizabeth Helme & Saint Clair das Ilhas & 3 \\
\hline
\end{tabular}




\begin{tabular}{|c|c|c|c|}
\hline & Walter Scott & $\begin{array}{l}\text { Obras de Walter Scott, } \\
\text { Hallidon Hill }\end{array}$ & 7 \\
\hline & Henry Fielding & Tom Jones & 1 \\
\hline & Daniel Defoe & Robinson Crusoe & 2 \\
\hline & Samuel Richardson & Pamela & 1 \\
\hline 1829 & Elizabeth Helme & Saint Clair das Ilhas & 4 \\
\hline & Walter Scott & Obras de Walter Scott & 4 \\
\hline & Henry Fielding & Tom Jones & 2 \\
\hline & Daniel Defoe & Robinson Crusoe & 1 \\
\hline 1830 & Jonathan Swift & Gulliver's travels & 2 \\
\hline & Daniel Defoe & Robinson Crusoe & 3 \\
\hline & Henry Fielding & Tom Jones & 2 \\
\hline & Regina Maria Roche & Amanda e Oscar & 1 \\
\hline & Elizabeth Helme & Saint Clair das IIhas & 2 \\
\hline & Elizabeth Helme & $\begin{array}{l}\text { Alberto ou os Desterrados de } \\
\text { Strathnavern }\end{array}$ & 4 \\
\hline 1831 & Elizabeth Helme & Saint Clair das Ilhas & 5 \\
\hline & & Luiza, ou a Cabana no deserto & 2 \\
\hline & Henry Fielding & Tom Jones & 2 \\
\hline & Daniel Defoe & Robinson Crusoe & 7 \\
\hline & Samuel Richardson & Pamela & 1 \\
\hline
\end{tabular}




\begin{tabular}{|l|l|c|}
\hline Walter Scott & $\begin{array}{l}\text { Obras de Walter Scott, } \\
\text { Ivanhoe, } \\
\text { Puritanos da Escócia, } \\
\text { Quentin Duward, } \\
\text { Roby Roy }\end{array}$ & 8 \\
\hline Jonathan Swift & Gulliver's travels & 4 \\
\hline Regina Maria Roche & Amanda e Oscar & 1 \\
\hline
\end{tabular}

Como se pode observar na tabela dos anúncios de 1821 a 1830 acima, parece haver interesse nas obras de ficção inglesas. O gráfico abaixo nos permite concluir que houve uma drástica queda na publicação de anúncios com obras inglesas do ano de 1825 para 1826, tendo havido, entretanto, uma recuperação em 1827. O aumento do número de anúncios é expressivo no ano de 1830, acompanhando o significativo aumento e divulgação dos locais onde estas obras eram oferecidas. ${ }^{143}$

\footnotetext{
${ }^{143}$ Apresento uma tabela no anexo final da dissertação com os nomes dos autores dos romances ingleses mencionados nos anúncios, bem como a quantidade de vezes que foi requisitado ou oferecido.
} 
O número de anúncios pode ser reflexo do aumento de livrarias no início do século oitocentista. De acordo com Hallewell ${ }^{144}$, o número de livrarias nas primeiras décadas do século XIX no Rio de Janeiro aumentou, sendo que, se 1808 , havia apenas duas; em 1820, o público fluminense contava com 16.

A análise dos anúncios do Diário do Rio de Janeiro nos permite investigar de 1821 a 1830 e verificar quais romances ingleses faziam parte do comércio livreiro fluminense.

Já em 1821, pode se encontrar o anúncio de um comprador para o livro Robinson Crusoé, de Daniel Defoe, contanto que este tivesse um "preço commodo".

Um anúncio do dia 09 de junho de 1821 nos alerta sobre a existência de uma Loja de Livros Ingleses.

“Na Loja de Livros Inglezes $N^{\circ}$ 25, rua do Ouvidor restão ainda para
vender alguns mais, ( ... )." Diário do Rio de Janeiro - 09 de
junho de 1821

Embora este anúncio não nos tenha informado o nome de nenhuma obra específica, nem o gênero de livros vendidos, este é mais um sinal da presença inglesa também no mercado livreiro. Como Gilberto Freyre já havia notado em sua obra Ingleses no Brasil ${ }^{145}$, os anúncios são diversas vezes misteriosos e refletem apenas pedaços da história da formação do público leitor fluminense do século XIX.

Em 1822, encontramos anúncios de livros, na sua maioria, de autores portugueses. Como no ano anterior, as obras do autor José Daniel Rodrigues da Costa apareceram mais freqüentemente, tais como Botas de curtiça, Acazos da fortuna, Almocreve das Petas e outros como Mil e huma noites, Atala, ou os Amores de dois selvagens no Dezerto, de Chateaubriand e Thesouro de meninos de Beaumont.

\footnotetext{
144 HALLEWELL, L. Books in Brazil. A History of the Publishing Trade. New York: Methuen; London: The Scarecrow Press, 1982. Trad. bras.: O livro no Brasil. São Paulo: Editora da Universidade de São Paulo, 2005.

${ }^{145}$ FREYRE, G. Ingleses no Brasil: Aspectos da influência britânica sobre a vida, a paisagem e a cultura do Brasil. Rio de Janeiro: Topbooks, 2000.
} 
As obras inglesas encontradas foram Vida e Viagens do Capitão Cook, Viagens do Amiral Ansom, à Roda do Mundo, Obras poéticas de Pope, Noites de Young e Paraíso Perdido e foram oferecidas por um professor de aulas particulares de inglês e francês instalado à rua dos Latoeiros $\mathrm{N}^{0} 12$.

O ano de 1823 apresentou um maior número de livros de prosa de ficção estrangeiros do que os anos anteriores. Entretanto, certos anúncios não nos apresentam o nome das "novellas" e livros à venda.

Um anúncio do dia 23 de junho de 1823 ressalta o interesse particular nas obras de Laurence Sterne (1713-1768), autor de romances como Tristram Shandy (1759) e A Sentimental Journey Through France and Italy (1768).

"Quem tiver para vender os livros seguintes: obras de Sterne em
Francez; os dois Corneilles, obras de Moriveaux; de Scarron: a
Biographie Universal, os Homens Ilustres do Plantarque, os Car[...]
de La Broyere, e a Biblioteca dos Theatros. Sendo novos, ou pouco
usados, procure na rua dos Ourives No 95 para tratar do preço
delles." Diário do Rio de Janeiro - 23 de junho de 1823

Os livros Viagens de Guliver. de Jonathan Swift e Pamella, de Samuel Richardson, foram também citados nos anúncios de compra ou procura de livros deste ano. O primeiro livro é mencionado em um anúncio particular de cobrança do empréstimo da obra. Assim como As Viagens de Guliver, Pamela de Richardson também é mencionado em um aviso particular, mas nele o requerente se oferece para comprar as obras.

Em um anúncio de 1824, a obra de Miguel Cervantes Dom Quixote foi anunciada pela primeira vez no Diário do Rio de Janeiro. Esta obra de grande sucesso na Europa foi também muito conhecida nas primeiras décadas do século XIX no Rio de Janeiro. No mesmo anúncio, vendem-se também livros dos autores franceses Jean Claude Fulchiron (Algar e Ainore), Arnaud (Selicourt), Guillaume Grivel (a llha Incognita) e a obra do inglês Daniel Defoe, Robinson Crusoé. O romance inglês é valorizado no anúncio por ser encadernado. 


“Na loja de Livreiro da rua Quitanda N. 36, se achão a venda as
seguintes Novellas: a Historia Americana por 100 réis, não há
felicidade Perpetua conto de Madama de Aulnoy por 400, Historia
de Paulhéa, e Abradate por 400., Azahia ou a Felicidade Conjugal
480 , Algar e Ainore ou os effeitos de huma funesta ambição 400 ,
Sapho no Salto de Lencate 480 , os Principes de Armenia 480 ,
Selicourty Novella de M. de Arnaud 610 também se acha as obras
de Ribiçom, Cruçué 4 volumes encadernados $4 \$ 000$, a IIha
Incognita 6 volumes $6 \$ 000$, D. Quixote de L. Mandia 6 volumes
$6 \$ 000$, (... ) e outras mais obras, que quem as quizer se
mostrarão." - Diário do Rio de Janeiro - 26 de janeiro de $1824-$
(grifo nosso)

O francês Plancher anuncia venda de livros no Diário neste ano. Seu anúncio é feito no idioma francês e nele podemos encontrar a obra inglesa Tom Jones de Henry Fielding.

"Les amateurs trouveront toujours chez M. Planchez un joli
assortiment de livres reliés (...) Tom Jones, en anglais, 2 vol. ornés
de figures." Diário do Rio de Janeiro - 14 de maio de 1824

O anúncio acima pode nos dar pistas sobre qual era o público alvo de Plancher. Primeiramente, seu anúncio é escrito em francês, levando-nos a crer que seu anúncio era voltado para os franceses residentes da região e para brasileiros que conheciam o idioma francês. O sortimento de livros também é descrito com detalhes. A obra Tom Jones é realçada pelo fato de ser ornada com figuras, o que tornaria o produto mais caro, selecionando ainda mais o público alvo de suas vendas.

Além de Tom Jones, as obras do autor Laurence Sterne e Amanda e Oscar, romance da escritora Regina Maria Roche, foram oferecidas em 1824.

Um estrangeiro citado nos anúncios deste ano foi David Carfrae, que faz uso de várias maneiras de interessar o público leitor do Diário do Rio de Janeiro. Apresentando-se como recém-chegado da Escócia, David Carfrae mostra-se inteirado das novidades que circulavam nos meios intelectuais europeus e disposto a continuar importando obras. Seu anúncio também destaca que as obras eram em língua inglesa e que as "novellas" seriam 
"modernas". Cita as obras de Byron e Scott, reconhecidamente famosas na Europa e no Rio de Janeiro. O valor das obras também é chamativo: a preços módicos.

“David Carfrae proximamente chegado de Edimburgo, faz sciente
ao respeitavel Publico que na rua do Ouvidor N. 110, tem para
vender hum surtimento de Livros, principalmente na Lingua Ingleza,
constando varios Auctores nas Sciencias da Medicina, Chimic,
Historia, Geografia, \&c., Viagens e todas as Novellas modernas, e
obra Poética, incluindo as de Lord Byron, Sir Walter Scott southeza
huma variedade de Commedias, Entremezes, livros de primeiras
letras, tem tambem hum surtimento de livros para contas, papel,
pennas, lacre, tudo que se ha de vender por preços modicos e
como pretende receber continuadamente de Inglaterra todas as
obras modernas, tanto nas differentes linguas de Europa, como a
Ingleza; espera merecer o patrocínio dos amantes da literatura." -
Diário do Rio de Janeiro - 06 de agosto de $\mathbf{1 8 2 4}$ (grifo nosso)

Este é um anúncio importante, pois, além de nos informar sobre a venda de obras do autor Walter Scott que estavam sendo oferecidas, menciona também o modo como estes livros estariam chegando no Brasil. Desta maneira, podemos concluir que Carfrae era um importador cuja principal fonte era a Inglaterra. Infelizmente, nos documentos do Desembargo do Paço do Rio de Janeiro não foi possível encontrar requerimentos feitos por este inglês.

A partir de 1825, o volume de anúncios de obras de ficção inglesas no Diário do Rio de Janeiro se intensifica, entretanto o número de "novellas francezas" ainda é superior. Neste ano, foram anunciados títulos como Diabo cocho e Aventuras de Estevão Gonçalvez de Lesage, Héloise de Rousseau, $A$ Ilha Incognita de Guillaume Grivel, Atala de Chateaubriand, Carlos e Fanny, de Ducray-Duminil e O Solitário de Terrasson, de Madame Merville. As obras Robinson Crusoe, Viagens de Gulliver, Pamella e da autora Ann Radcliffe foram os romances ingleses encontrados em anúncios de venda deste ano, assim como a obra Sinclair das Ilhas de Elizabeth Helme.

Os romances de Walter Scott também foram oferecidos, mas infelizmente 0 anúncio não conta com uma lista de quais eram estas obras. A escassez de 
informações também aguça a nossa curiosidade em relação aos leilões realizados por Dodsworth, que afirma ter livros ingleses e franceses, porém não especifica quais. Esta poderia ser uma técnica de venda para que mais pessoas comparecessem ao local onde outros objetos estariam sendo leiloados.

O volume de anúncios de romances ingleses importados da Europa no ano de 1826 no Diário do Rio de Janeiro sofre uma queda. Entretanto, é válido ressaltar que muitos livreiros anunciam "novellas" sem mencionar nem títulos nem autores.

“Na loja de livros de Cremiere, rua dos Ourives N. 178, ha para vender
(...), obras de Schakspar em Inglez 23 vol. em $8^{\circ}$ por $24 U 000$ rs.,
Novellas Inglezas por 640 o vol.; (...), tambem alugão se por mez, ou dias
por preço commodo (...)"- Diário do Rio de Janeiro - 13 de janeiro de
1826

A loja do francês Cremière estava situada na agitada Rua dos Ourives, $N^{0} 178$, assim chamada pela grande quantidade de negociantes de ouro e joalheiros. Desde o ano anterior, este livreiro também alugava livros por mês ou por dia. De acordo com Nelson Schapochnik ${ }^{146}$, as lojas de livros que alugavam obras já existiam nas últimas décadas do século XVIII na França.

Em 1827, o número de títulos de obras de prosa de ficção inglesa aumenta neste ano, sendo sete os autores citados nos anúncios: Daniel Defoe, Elizabeth Helme, Henry Fielding, Jonathan Swift, Regina Maria Roche, Samuel Richardson e Walter Scott.

Muitos anúncios destacavam o interesse pela compra de certas obras, como no exemplo abaixo:

"Quem tiver a Novella intitulada, Amanda e Oscar, e a queira vender, póde procurar no Campo da Acclamação casa N. 15." - Diário do Rio de Janeiro - 05 de abril de 1827

146 SCHAPOCHNIK, Nelson. Os jardins das delícias: gabinetes literários, bibliotecas e figurações de leitura na corte imperial. Tese de doutorado. Departamento de História da Faculdade de Filosofia, Letras e Ciências Humanas da Universidade de São Paulo, 1999. 
O Diário se portava como um veículo de comunicação entre os leitores à procura de prosa de ficção e os possíveis vendedores.

É em 1827 que João Baptista Bompard anuncia a História de Saint Clair das Ilhas. Este livreiro comercializava na Rua dos Pescadores $N^{0} 49$ "novellas novas" e romances "em bom uzo". Ele já havia oferecido títulos franceses e portugueses nos anos anteriores, incluindo literatura infanto-juvenil como as obras em fascículos da Bibliotheca Juvenil: Gato de Botas, Capinha Roxa e a fada, História da Bella Dormente e Barba Azul.

Como nos anos anteriores, nos anúncios de 1828, existem muitas ofertas de livros que não foram especificados, porém chama atenção o sortimento de livros com figuras e obras encadernadas.

O volume de obras de prosa de ficção oferecidas nos anúncios da seção "LIVROS A'VENDA" foi grande, se comparado aos anos anteriores. A maior parte dos livreiros e comerciantes de livros oferecia romances franceses. Entretanto, obras como as do autor Walter Scott foram também citadas nos anúncios.

Outra categoria de negociação de livros que pode ser encontrada nos anúncios foi o aluguel. Por meses ou por dias, um leitor poderia alugar um romance. Infelizmente, o valor do aluguel das obras não foi encontrado nos anúncios pesquisados. Porém, é também por meio destes anúncios de aluguel de livros que podemos encontrar as obras de ficção importadas, como o anúncio abaixo:

"Na rua dos Ourives N. 86 se alugão livros Francezes e
Portuguezes, entre estes se achão as melhores Novellas
Portuguesas como Gilbras de Santilhana ${ }^{147}$, Novellas Orientaes,
Mil e huma Noite, Viagens de Gulliver, Robinson Crusoé,
Celestina, Noites Clementinas, ditas Romanas, D. Quixote de la
Mancha, Deão de Kellerine,Tom Jones, Victor ou o Menino da
Selva, o Filosofo Inglez, Piolho Viajante, Gabinete Histórico,
Carolina de Lichtfield, e outras muitas mais e entre aquelas se
achã as obras com letras de Pigault Lebrun, S. Jouy, Walter Scott,

\footnotetext{
${ }^{147} \mathrm{O}$ anunciante cita como uma das melhores novelas portuguesas a obra francesa de Lesage Gil Blas de Santillana. Tal erro pode ter sido feito por esta obra ter sido importada como uma tradução portuguesa.
} 


Prévost, Madame de Genlis, Madame de Montolieu, Montesquieu,
le voyagens Français de la Porte, Rápertoire du Tréatre Français
et autres Romains choisis, dos quaes tem Catalogos Impressos
ha tambem para vender Santa Clar das Ilhas 4 vol. ,vida de João
de Castro, 1 vol, Vida e amores de Heloise e Abeilard, 2 vol. (...) o
Consorcio das Flores, A arte de conhecer os homens 1 vol., o
Velho paisano polonez, 1 vol. (...). O dono da casa roga a todas
aquellas pessoas que Ihe tem feito a honra de serem seus
assignantes, cujos, tem alguns livros em seu poder a muito
tempo, o favor de os entregar para evitar o encommodo de [?] a
casa dos ditos Snrs. Procuralos." - Diário do Rio de Janeiro - 01
de agosto de 1828

Como nos anúncios de venda, os leiloeiros, por diversas vezes, não especificaram as obras a serem leiloadas. Podem-se encontrar decrições de leilões de objetos importados variados e "livros inglezes" e "francezes".

Outros leilões anunciados especificaram os nomes das obras, ou ao menos, seus autores. Os leiloeiros que mais anunciaram livros importados neste ano foram Dodsworth, Douville e Carlos Cannel.

O leiloeiro Dodsworth, que diversas vezes anunciou seus produtos variados, tais como fazendas, cerâmicas, leques, papéis e livros, publicava também no periódico Jornal do Comércio. ${ }^{148}$

Assim como Dodsworth, Douville também anuncia seus leilões no Jornal do Commercio. É interessante notar que este comerciante não somente restringia a vender produtos importados, mas também costumava comprar produtos usados:

Douville e Comp. Fazem leilão hoje Quarta feira do crrente em sua casa rua da Quitanda n. 99 ás 6 e meia da tarde, de huma grande porção de fazendas de diversas qualidades bem como: moveis de casa de bom gosto, brins, chitas, riscados, fitas, lenços, botões, fechaduras \&c. Na mesma casa se recebem

\footnotetext{
${ }^{148}$ O Jornal do Comércio, periódico publicado desde 1827 é uma fonte de valor inestimável em relação aos anúncios de romances. O trabalho de iniciação científica de Thatiana Domingos Moura revela seus principais anunciantes e obras inglesas. O negociante que mais se destacou nesta pesquisa foi J. J. Dodsworth.
} 
fazendas para vender de todas as qualidades, comprão-se livros, jóisas, ouro, e prata velha." Jornal do Commercio - 2 de janeiro de 1828

Na rua do Ouvidor, o francês Goupil realizava leilões de lotes de livros ingleses e franceses e de objetos e escravos. Infelizmente, não há evidências de quais livros ingleses ele oferecia. O mesmo mistério cerca os livros do leiloeiro Carlos Cannell em 1829:

LEILÕES
Carlos Cannell faz leilão hoje Terça feira 14 do corrente, em suia
casa na rua detraz do Hospício $N$. 33 de diverças ferragens (...)
livros em Inglez e Francez, (...), tudo será vendido infallivelmente
as 10 horas e meia. Diário do Rio de Janeiro - 14 de junho de
1829

O leiloeiro J. J. Dodsworth também oferece obras de Sterne no meio de outros livros, bem como tecidos. Dodsworth realizava seus leilões de produtos. Entre os produtos oferecidos, encontramos a coletânea Fielding's works, em um leilão em sua casa $\mathrm{N}^{0} 38$ da Rua da Alfândega em 1831.

É também na Rua do Ouvidor o estabelecimento de um importante personagem da história dos livros no Brasil que é citado pela primeira vez em 1829 no Diário: Albino Jordão.

"Na loja de livros de Albino Jordão, na rua do Ouvidor N. 138, acha-
se á venda o seguinte em Portuguez: Protecção á Franceza por
José Daniel, 160 rs.; dita dos Inglezes, 100 rs; (...) Merope,
Tragedia de Mr. Voltaire, 320 rs; Successos do Aletenjo, 100 rs.;
(...) Extrato das Cartas de Maria Wolltsnecraft 320 rs.; (...); Cartas
de huma Peruviana, ou Historia de huma Princeza do Perú, 2 vol,
960 rs." - Diário do Rio de Janeiro - 15 de junho de 1829

A lista dos livros por ele comercializados é longa, contando com obras de ficção, tais como Mil e Hum Quarto de Hora, Filosofa por Amor, Ilha Incógnita, Telêmaco e obras de Chateaubriand, entre outros, sempre vendidos por "preços commodos". Os romances ingleses oferecidos foram Saint Clair das Ilhas, Tom Jones e Robinson Crusoé. 
"Na loja de livros de Albino Jordão, na rua do Ouvidor, N. 138, vendemse as seguintes Novellas encadernadas: (...) Tom Jones, ou o Engeitado 4 vol. $6 \$ 000$ rs.; Robson Crosoè 4 vol. 5\$000; (...)" - Diário do Rio de Janeiro - 29 de dezembro de 1829

Albino Jordão utilizava os anúncios do Diário do Rio de Janeiro para mostrar seu interesse em comprar obras como Saint Clair das Ilhas e Tom Jones. Ele também nos oferece uma pista de que o seu público-alvo eram os estudantes, já que se dispõe a comprar "quaesquer dos Livros que se dão nas Academias, ou Aulas Públicas desta Corte $^{149,}$.

Podemos supor que este era o público alvo da loja de Campos Bellos na Rua do Ouvidor $\mathrm{N}^{0} 75$, já que seus anúncios avisam que ele comprava e vendia livros usados por "preços módicos". Esta loja ofertava Robinson Crusoe, Saint Clair das Ilhas e Alberto, ou o Desterrado de Strathnavern.

O livreiro e tipógrafo J. Cremiere também oferecia romances ingleses, como Saint Clair das Ilhas, Robinson Crusoé, Amanda e Oscar, Tom Jones e Viagens de Guliver, em sua loja localizada na Rua dos Ourives N. 86.

Neste ano, o número de vezes em que os livros de ficção ingleses foram mencionados é duas vezes maior do que o do ano anterior. Há um aumento tanto na variedade dos autores e títulos, quanto no número de publicação de anúncios.

As lojas onde se poderiam encontrar as obras inglesas eram localizadas nas ruas próximas à Alfândega. Na Rua dos Ourives $N^{0} 86$, o leitor poderia comprar Saint Clair das Ilhas e na loja de Evaristo da Veiga, na Rua da Quitanda, poderia adquirir os livros Tom Jones, Robinson Crusoe, Vida de Napoleão Bonaparte, Ivanhoe, Puritanos da Escócia, Quentin Duward, Rob Roy, Luiza e Amanda e Oscar.

Para melhor visualização da oscilação de oferta e procura de romances ingleses nos anúncios estudados de acordo com os seus respectivos autores, dividi o gráfico da tabela acima em duas partes.

${ }^{149}$ Diário do Rio de Janeiro, 30 de setembro de 1829. 
Considerando os romancistas ingleses citados nos anúncios e visualizados nos gráficos acima, dedico as próximas páginas a agrupar os romances e indicar onde e quando foram encontrados, de acordo com a Gazeta do Rio de Janeiro e o Diário do Rio de Janeiro. Isto nos permitirá traçar o possível paradeiro dos romances ingleses importados apontados no primeiro capítulo, assim como também nos auxiliará a concluir se os autores das obras mencionadas nos anúncios são os mesmos que foram mencionados nos documentos da Alfândega, ou se trata de outros títulos. 


\section{Ann Radcliffe}

A autora inglesa Ann Radcliffe (1764 - 1823) foi uma das pioneiras na literatura gótica. Sua obra conta com seis romances: The Castles of Athlin and Dunbayne de 1789, A Sicilian Romance de 1790, The Romance of the Forest de 1791, The Mysteries of Udolpho de 1794, The Italian de 1797 e Gaston de Blondeville de 1826.

Um grande sortimento dos melhores romances de Ann Radcliffe é anunciado por João Pedro da Veiga em 1825. O anúncio afirma estas obras chegaram recentemente chegados da França. Infelizmente, não podemos afirmar quais dos romances da autora haviam aportado no Rio de Janeiro.

\section{Daniel Defoe}

A obra Robinson Crusoé de Daniel Defoe foi oferecida em 1817 pela loja da Gazeta e descrita como "huma nova Edição da Vida e Aventuras admiraveis de Robinson Crosué, 4 vol. por 4.800 réis; novela que tem merecido geral aceitação" ${ }^{150}$. Foi também menção constante em quase todos os anos de publicação do Diário na década de 1820. O valor da obra variou entre 950 e 1100 réis. Desde 1821 até 1831 , compradores e livreiros especializados ou não publicaram anúncios mostrando o interesse por esta obra.

$\overline{150}$ Gazeta do Rio de Janeiro, 09 de abril de 1817. 


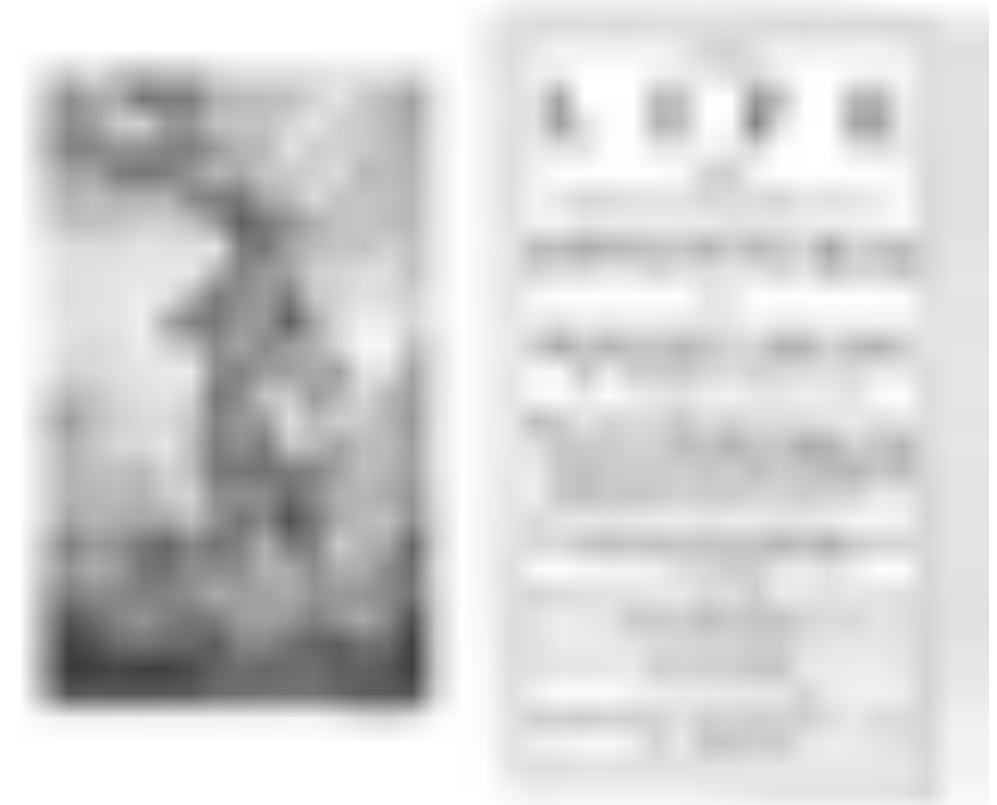

Frontispício da primeira edição - 25 de abril de 1719

\section{Elizabeth Helme}

A obra Sinclair das Ilhas da romancista Elizabeth Helme foi anunciada de 1825 a 1829. Era oferecida em lojas de livros, armazéns e estabelecimentos de aluguel de livros. A autoria desta obra foi discutida por Marlyse Meyer no ensaio "O que é, ou quem foi Sinclair das Ilhas"151.

${ }^{151}$ MEYER, Marlyse. "O que é, ou quem foi Sinclair das Ilhas?" in Revista do Instituto de Estudos Brasileiros. São Paulo: Universidade de São Paulo, 1973, n. 14, pp. 37-63. 
A autoria da obra St. Clair of the Isles; of the Outlaws of the Barra: A Scottish tradition era erroneamente creditada a madame Montolieu. St Clair of the Isles foi publicado em 1803 por Elizabeth Helme e coube a Montolieu a tradução para o francês. De acordo com Meyer, a obra Saint Clair das Ilhas foi um dos livros mais vendidos no cenário europeu que os franceses consideravam como típico roman anglais.

Helme já havia alcançado reconhecimento na Europa seis anos antes desta publicação com a obra Louisa, or the Cottage of the Moor, que chegou ao Brasil em tradução como Luiza ou o Casal no Bosque, e Albert, or the Wilds of Strathnavern, que aportou no Brasil em tradução com o título de Alberto, ou o Deserto de Strathnavern. ${ }^{152}$

A "novela novamente chegada" Luiza, ou o casal no Bosque foi anunciada na Gazeta do Rio de Janeiro em 1816, novamente por João Pedro da Veiga e Cia e na loja de livros da Praia dos Mineiros em 1831. A obra Alberto ou os Desterrados é anunciada por Bompard em 1827 e em 1830 por Campos Bellos.

152 MEYER, Marlyse. "Machado de Assis lê Saint Clair das llhas" in Literatura e Sociedade, São Paulo: Universidade de São Paulo, 1998, n. 3, pp. 17-33. 


\section{Henry Fielding}

As obras de Henry Fielding circulavam nas lojas de livros mais proeminentes de acordo com os anúncios. Em 1817, Tom Jones foi oferecida na loja da Gazeta e entre os anos de 1824 e 1831, Plancher, Albino Jordão, Cremière, João Pedro da Veiga e seu irmão Evaristo Ferreira da Veiga o anunciaram.

The History of Tom Jones, primeiramente publicado em 1749, é descrito em um anúncio como uma "novella nova e engraçada" ${ }^{153}$, que conta a história de um enjeitado criado por uma família da aristocracia rural que se torna um jovem de grande fascínio pessoal e que atrai a atenção e a paixão de diversas mulheres.

\section{Jonathan Swift}

Gulliver's Travels de Jonathan Swift foi publicado em 1726 e chega no Brasil já nas primeiras décadas do século XIX. Foi anunciado pela loja da Gazeta em 1817, procurado e oferecido desde 1825 até 1831 nos anúncios dos jornais pesquisados. Os negociantes Cremière, Albino Jordão e Evaristo da Veiga foram responsáveis por alguns destes anúncios.

$\overline{153}$ Gazeta do Rio de Janeiro, 10 de maio de 1817. 


\section{Laurence Sterne}

O autor Laurence Sterne é citado em anúncios em 1823, 1824 e 1830. Um particular procura obra deste autor em 1823 e uma loja a oferece a particulares. No ano seguinte, um comprador a procura e Paulo Martin a oferece. Dodsworth também anuncia uma obra do autor em 1830.

\section{Regina Maria Roche}

Além de dois anúncios particulares, de um comprador e de um leitor que havia perdido a obra, o livro Amanda e Oscar de Regina Maria Roche foi oferecido em 1824 por João Baptista Bompard, em 1830 por Cremière e em 1831, por João Pedro da Veiga.

O original em inglês The Children of Abbey conta a história de Amanda, heroína que sobrevive a perseguições, tentativas de estupro e diferentes tentações em sua viagem com o seu irmão pela Irlanda, Escócia, Inglaterra e País de Gales.

\section{Samuel Richardson}

Já em 1814, na loja da Gazeta a obra Pamela de Samuel Richardson é oferecida e, entre 1825 e 1831, é anunciada no Diário do Rio de Janeiro, sendo que, em 1823, um comprador a procura. Em 1827, a obra História de Clara Harlowe é oferecida por um livreiro e, em 1828, procurada por um leitor. 


\section{Walter Scott}

As obras de Walter Scott são oferecidas desde 1824 até 1831. Apesar de alguns títulos serem citados, como Hallidon Hill, Ivanhoe, Puritanos da Escócia, Quentin Durward e Rob Roy, grande parte dos anúncios não conta com uma lista de quais obras eram oferecidas. Os anunciantes preferiam descrever como "obras de Walter Scott". Este fato pode indicar o renome que o autor Walter Scott detinha nas primeiras décadas. Leitores eram atraídos para as lojas pelo fato de que poderiam encontrar alguma obra deste autor.

A partir da lista dos autores de romances ingleses citados nos periódicos, podemos esboçar um mapa das lojas que ofereciam romances ingleses no Rio de Janeiro de 1808 a 1831. Interessa-nos refletir sobre certos aspectos do comércio de romance inglês no Rio de Janeiro. Objetivamos ressaltar a relevância desses comerciantes no mercado livreiro que começava a surgir. Três perguntas conduzem esta narrativa: Quais eram estas casas de negócios? Quem eram seus sócios? Quais os romances ingleses eram mais oferecidos?

\subsection{Aos armazéns de commodo preço}

Ao refletir sobre estas três questões, foi necessário entender qual a dinâmica particular das ruas do Rio de Janeiro, bem como dos negociantes da região. Nesta parte do trabalho, apresento a prosopografia coletada dos negociantes de livros citados nos anúncios e nas informações de estudiosos da história do livro no Brasil. O segundo objetivo é confirmar a hipótese de que os mesmos romances ingleses que constavam das listas de importação da Alfândega seriam comercializados no Rio de Janeiro.

Nas próximas páginas, iremos traçar um possível localização das lojas que ofereciam romances ingleses décadas de 10 a final da 20 do século XIX. A Planta da Cidade de S. Sebastião do Rio de Janeiro ${ }^{154}$ foi alterada para que as ruas com negociantes que vendiam romances ingleses pudessem ser destacadas conforme a legenda.

\footnotetext{
154 Planta da cidade de S. Sebastião do Rio de Janeiro. Debret, Jean Baptiste, 1768-1848. Disponível em: http://www.brasiliana.usp.br/bbd/handle/1918/624520093 Acesso: maio de 2013.
} 
Como podemos visualizar no mapa da página seguinte, as lojas nas três primeiras décadas de 1800 estavam concentradas no centro da cidade e próximas à Alfândega. Nas próximas páginas, apresentarei os resultados da análise prosopográfica dos negociantes dos romances ingleses encontrados nos anúncios. As lojas encontram-se organizadas de acordo com a localização geográfica, com a finalidade de facilitar a organização dos dados. Com este estudo, espera-se apresentar possíveis trajetórias destas obras. 

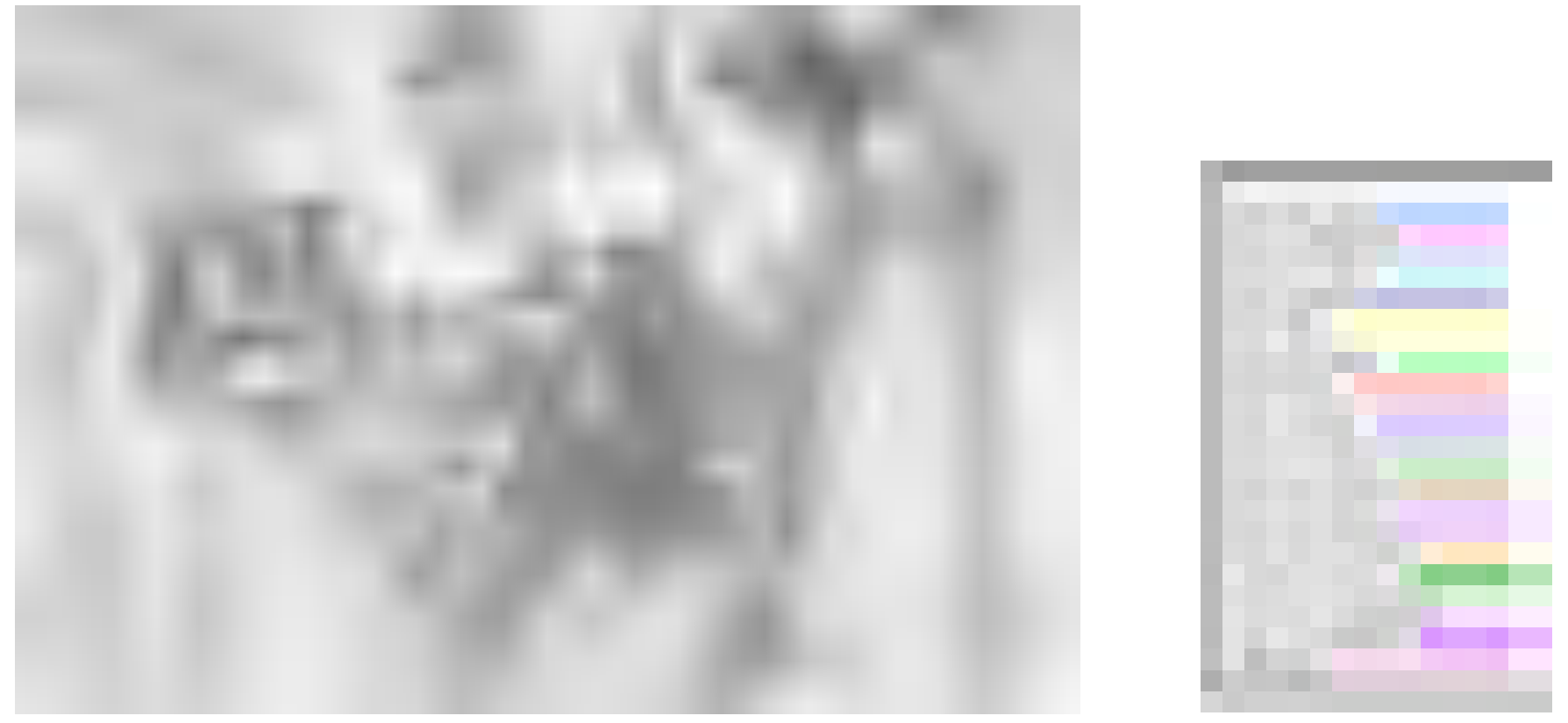

As ruas destacadas no mapa eram o destino daqueles que procuravam romances ingleses entre 1808 e 1831 . Tomemos a Rua da Alfandega como nosso ponto de partida. 


\section{Rua da Alfândega e Praia dos Mineiros}

O começo da história da Rua da Alfandega foi o caminho entre a zona praieira até a Mata-Cavalos ou Mata-Porcos. Ela é uma das ruas mais antigas da região. Foi nesta rua que se instalaram os primeiros comerciantes ingleses que chegaram após a abertura dos portos e os moradores poderiam encontrar armazéns de produtos variados, lojas e leilões. Uma destas firmas foi a de Freese \& Blackenhagen. Nas primeiras décadas do século XIX, eles possuíam uma casa de negócios, onde comercializavam fazendas e artigos variados. Estes dois negociantes fizeram requerimentos de romances ingleses já em 1810.

Em 1821, Luis Francisco Saturnino da Veiga transfere sua loja, antes na Rua do Ouvidor, e lá oferece livros diversos e estabelece sua escola de instrução. Este pioneiro do comércio livreiro fluminense vendia bilhetes de loteria, jornais e assinaturas de periódicos, livros de direito, "novelas" completas e até mesmo com volumes "truncados". De acordo com Ubiratan Machado ${ }^{155}$, os filhos João Pedro e Evaristo frequentaram a sua loja e ali aprenderam o ofício do pai.

Na botica de Estevão Alvez de Magalhães, na década de 1820, o leitor poderia adquirir a obra Saint Clair das Ilhas ${ }^{156}$. De acordo com Flavio Coelho Edler ${ }^{157}$, as boticas constituíam importantes espaços de sociabilidade. Em anúncios do Diário do Rio de Janeiro, podemos conferir a diversidade das atividades e produtos ali oferecidos: bilhetes de loteria, notícias de escravos fugidos, consulta com cirurgiões ${ }^{158}$, oferta de trabalho ${ }^{159}$. Edler afirma que tamanha era a relevância das discussões intelectuais da botica de

\footnotetext{
${ }^{155}$ MACHADO, Ubiratan Machado. História das livrarias cariocas. São Paulo: Edusp, 2012.

${ }^{156}$ Diário do Rio de Janeiro - 23 de fevereiro de 1825.

${ }^{157}$ EDLER, Flavio Coelho. Boticas \& pharmacias: uma história ilustrada da farmácia no Brasil. Rio de Janeiro: Casa da Palavra, 2006, p. 70.

${ }^{158}$ Diário do Rio de Janeiro, 26 de junho de 1826.

${ }^{159}$ Diário do Rio de Janeiro, 12 de fevereiro de 1828.
} 
Estevão Alves que até mesmo foi utilizada como um dos locais das reuniões que antecederam a abdicação de d. Pedro.

No mesmo ano, a alguns metros dali, John George Dodswoth, ou J. J. Dodsworth, gerenciava seus leilões. Dosdworth foi casado com uma brasileira e seu filho se tornaria o $2^{\circ}$ barão de Javari. Ele oferecia itens diversos como ferramentas, móveis, fazendas e livros. Ele foi o responsável por anunciar leilões de obras de Scott, Fielding e Sterne. Dodsworth também administrava bens de outros comerciantes, como foi o caso de João Baptista Loyseleur em 1830, que chegou a importar romances em 1818.

Dodsworth anunciou diversas vezes no Diário do Rio de Janeiro, bem como no Jornal do Commercio.

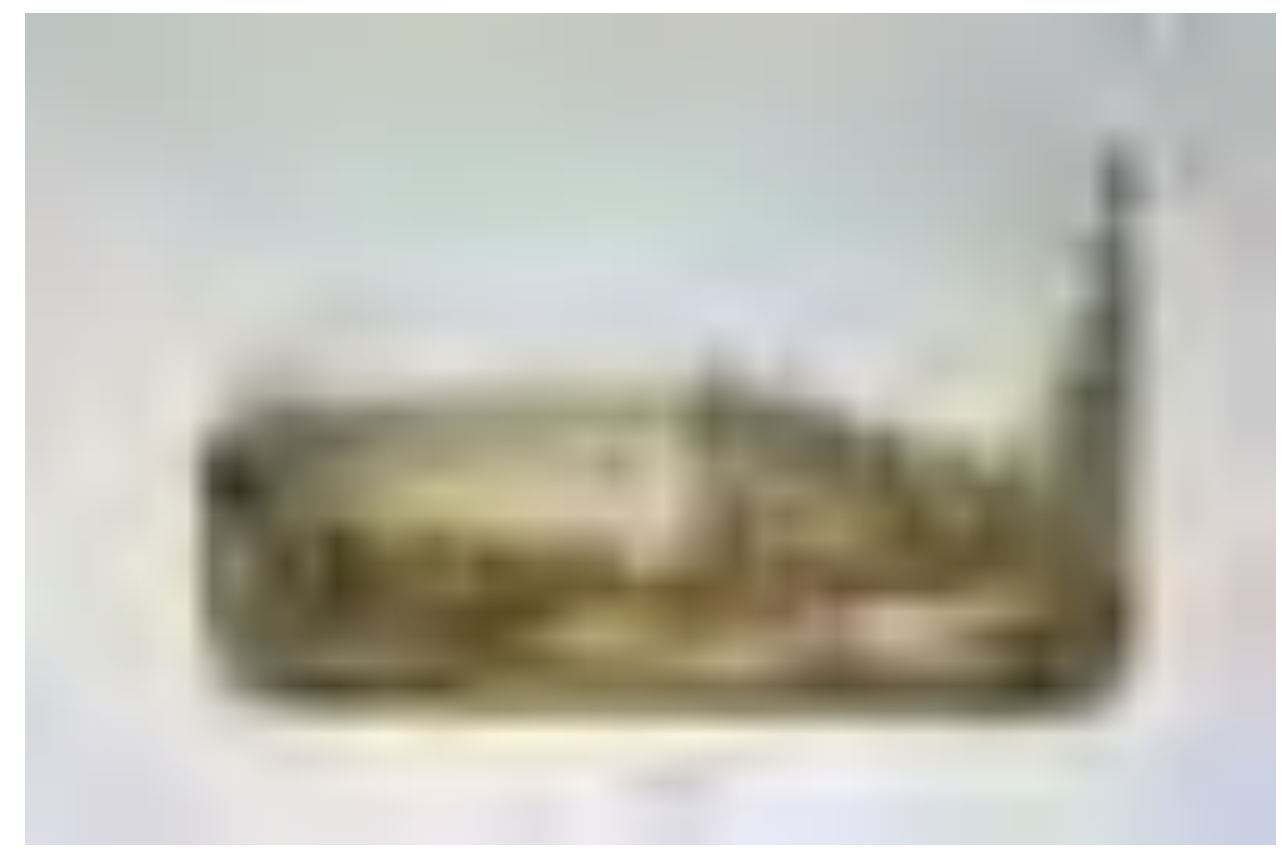

Alfândega (Praia dos Mineiros) - Pieter Godfred Bertichen

Em 1831, um livreiro cuja casa era situada em Praia dos Mineiros, 49, anunciava Robinson Crusoe, Saint Clair das Ilha, Luiza, ou a Cabana no deserto, Gulliver's travels e Pamela. 


\section{Rua dos Pescadores}

Próxima à Praia dos Mineiros, afamada pelos charcos, mosquitos e mangues, a área da Rua dos Pescadores foi sendo drenada e expandiu-se em direção ao interior. Após a instalação da corte, vários personagens importantes residiram nesta rua como Maria Graham.

Nesta rua, Henrique Muller (ou Miller) trabalhou de 1808 a 1831. Apesar de não ser livreiro, encontramos uma lista na Mesa do Desembargo do Paço de 1818 com o interessante número de 6 caixas de livros a ele endereçados, incluindo a obra Beauties of Sterne.

É para a Rua dos Pescadores que Paulo Martin, no final de sua carreira no Rio de Janeiro, muda sua loja e a repassa a João Baptista Bompard. Durante sua direção, este livreiro anuncia no Diário do Rio de Janeiro a venda de Beauties of Sterne e Amanda e Oscar de Regina Maria Roche em 1824, e Saint Clair das llhas e Alberto ou os Desterrados em 1827. Em 1828, a loja é adquirida por Evaristo da Veiga.

O filho do bem sucedido livreiro Francisco Saturnino da Veiga, Evaristo da Veiga, anuncia diversas obras como Tom Jones, Guliver's travels e obras de Walter Scott. 


\section{Rua de São Pedro}

Considerada uma das ruas mais antigas do Rio de Janeiro, data de 1630. Recebeu este nome devido à igreja construída pela Irmandade dos Clérigos de São Pedro. Nesta rua, esquina com a Rua da Quitanda, os irmãos Veiga estabeleceram sua livraria em 1823. Esta teria sido a loja de Manoel Joaquim da Silva Porto, uma das mais tradicionais da cidade. De acordo com Ipanema, a loja possuía localização privilegiada, pois a Rua São Pedro era um caminho em direção à cidade nova e a Rua Quitanda era outra via de passagem importante para quem viesse da Lapa, Desterro e Catete. ${ }^{160}$ Nos anúncios de João Pedro da Veiga encontramos como endereço Rua S. Pedro, n. 166, esquina com a Rua Quitanda. Ele oferecia as obras de Ann Radcliffe, Saint Clair das Ilhas, Robinson Crusoé, Tom Jones, Gulliver's travels, obras de Walter Scott, Hallidon Hill, Luiza, ou a Cabana no deserto e Amanda e Oscar.

Em 1825, Saint Clair das Ilhas era oferecido no mesmo anúncio pelo armazém de instrumentos musicais de Ferguson \& Crockeat, pela loja de João Pedro da Veiga e pela loja de Francisco Nicolao Mandillo.

${ }^{160}$ IPANEMA, Cybelle. Silva Porto: livreiro na Corte de D. João. Editor na Independência. Rio de Janeiro: Capivara, 2007, p. 34. 


\section{Rua Direita}

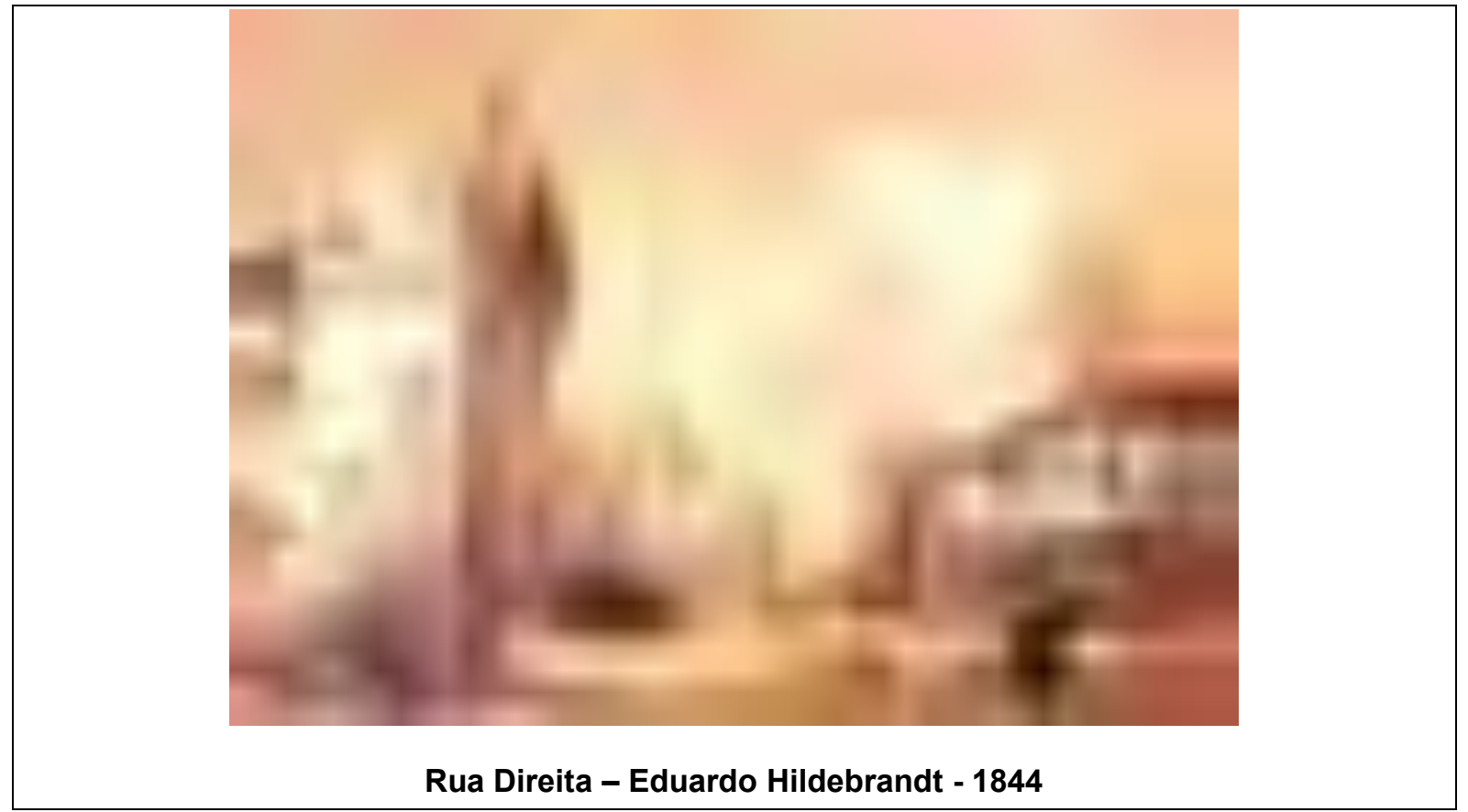

A rua Direita abrigou importantes construções para a história do Brasil. Nesta rua, esquina com a rua São Pedro, foi instalado o primeiro Banco do Brasil em 1808. Já na segunda metade do século XVIII, uma das mais importantes capelas foi ali construída: a N. S. do Carmo. Nesta capela, importantes fatos da história do século oitocentista ocorreram: o casamento de D. Pedro com D. Leopoldina de Habsburgo e o juramento da 
primeira constituição. Em 1837, foi constituído o Gabinete Português de Leitura. Nesta mesma rua, foi instalada a Praça do Comércio.

Ali era possível encontrar em 1816, na loja de Pierre Constant Dalbin, um exemplar de Pamela. Dalbin é um dos requerentes de liberação de livros encontrados nos documentos da Mesa do Desembargo do Paço até 1820.

Em 1824, um particular de nome João Antonio Ferrisse desejava vender as Obras completas de Walter Scott em inglês com 52 volumes.

Os sócios Bourdon e Fry possuíam sua casa de negócios na rua Direita, n. 62 em 1827. Estes estrangeiros não eram especializados em livros. Em 1816, dentre os diversos títulos listados nos documentos da Alfândega, encontramos a obra Pamela de Samuel Richardson. Leiloavam artigos franceses já em 1817 e os descreviam nos anúncios como "todos de melhor gosto" e "vindos de Paris e Londres".

No sobrado da rua Direita, n. 130, uma loja oferecia nos anos 1825, 1826, 1827 as obras Robinson Crusoe, Saint Clair das Ilhas, Guliver's travels, Pamela, Tom Jones, Emma, ou filha do desgosto e obras de Walter Scott.

\section{Rua do Lavradio}

De acordo com Gerson ${ }^{161}$, esta rua representou um papel de "alto relevo na nossa vida artística, política e social” ${ }^{\text {162 }}$ e é lá que também encontramos um livreiro interessado em vender a História de Clara Harlowe.

\section{Rua do Ouvidor}

\footnotetext{
${ }^{161}$ GERSON, Brasil. História das Ruas do Rio e da sua liderança na história política do Brasil. Rio de Janeiro: Lacerda Ed., 2000.

162 GERSON, Brasil. História das Ruas do Rio e da sua liderança na história política do Brasil. Rio de Janeiro: Lacerda Ed., 2000, p. 220.
} 


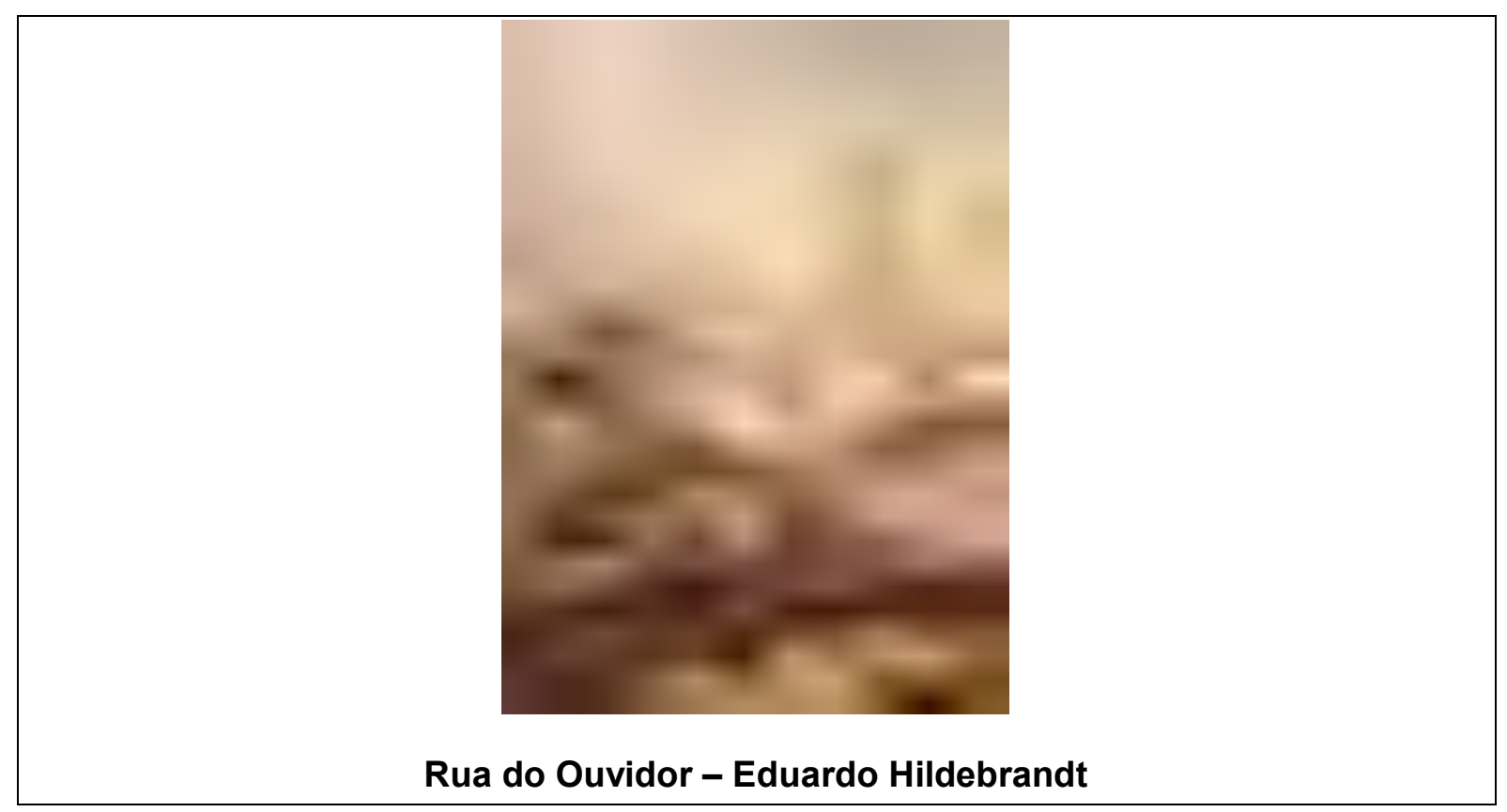

A Rua do Ouvidor é especial porque possuímos um relato sobre os hábitos, costumes e mudanças no testemunho de Joaquim Manuel de Macedo em seu livro Memórias da Rua do Ouvidor. Se até a instalação da corte a rua do Ouvidor nada se distinguia das demais do centro, ela então se transformava em um centro de comércio. Os primeiros representantes do comércio de mercadorias estrangeiras se instalaram nesta rua. Negociavam fazendas, objetos de luxo e livros. Além de produtos, a população encontrava também serviços como modistas, cabeleireiros, sorveteiros e doceiros.

Um dos primeiros negociantes a estabelecer-se nesta rua foi José Borges de Pinho, associado a Manoel Mandillo já em 1818. José Borges de Pinho foi o responsável por importar obras diversas, incluindo Pamela em 1815.

Outro estrangeiro interessado neste novo mercado foi Carlos Durand, negociante da Normandia, que importa romances ingleses já em 1816 e os negociava na Rua do Ouvidor, n. 18.

Vizinhos à loja de Durand, a firma de Lazan e Vial frequentemente anunciou na Gazeta do Rio de Janeiro no final da década de 10 oitocentista. Em 1817, importaram cerca de 100 obras, porém não anunciaram nenhuma nos periódicos. Entretanto, 
anunciam outros produtos como sal, manteiga, fazendas, o que pode indicar que esta firma importava livros e os repassava para algum livreiro.

A Rua do Ouvidor tinha grande influência francesa, como Victor Jacquemont afirma:

No Rio sustentamos com grande vantagem os nossos créditos de cabeleireiros e mestre de dança. A Rua Vivienne da terra, que aqui se chama do Ouvidor, está apinhada de modistas, alfaiates e penteadores de Paris."163

Um dos franceses atraídos para esta "Rua Vivienne da terra" foi Pierre Seignot Plancher. Pierre René François Plancher de La Noé morou em Paris até 1824, quando foi exilado graças a sua simpatia pelas idéias bonapartistas. Na França, era editor e responsável por diversas livrarias. Teria escolhido o Brasil como seu novo país, pois, segundo Hallewell ${ }^{164}$, as perspectivas do país no começo da década de 20 pareciam animadoras. Já em maio de 1824, Plancher abriu uma loja de livros novos e usados na rua dos Ourives em sociedade com Justin Victor Cremière. Após alguns meses, começou a publicar obras em português.

Plancher, Impressor, Livreiro estabelecido na rua dos Ourives N. 60, participa ao Público que ele compra todos os livros em segunda mão, que se acharem usados, as pessoas que o tiverem podem-se dirigir no lugar indicado. - Diário do Rio de Janeiro - 31 de março de 1824

Na sua livraria, era possível encontrar livros "novamente chegados", estampas, papéis e também tomava livros em "commissão". Ele foi um dos primeiros livreiros a adotar um nome fantasia para seu estabelecimento: Livraria Brasílica Francesa.

Plancher foi um inovador na prática de impressão no Brasil, pois trouxe consigo os mais modernos métodos e técnicas da França. De acordo com Hallewell, Plancher foi o responsável pela introdução das loterias de livros no Brasil. Este tipo de comércio de

163 GERSON, Brasil. História das Ruas do Rio e da sua liderança na história política do Brasil. Rio de Janeiro: Lacerda Ed., 2000, pág.43.

${ }^{164}$ HALLEWELL, L. Books in Brazil. A History of the Publishing Trade. New York: Methuen; Lindon: The Scarecrow Press, 1982. Trad. bras.: O livro no Brasil. São Paulo: Editora da Universidade de São Paulo, 2005. 
livros já era muito conhecido em Paris. A loteria se tornou, então, uma prática constante e foi por diversas vezes anunciada no Diário durante a década de 20 do século XIX no Rio de Janeiro.

"A Loteria de Livros de Pedro Plancher hade extrair impreterivelmente no dia 15 do corrente mez de Outubro. M. Plancher convida aos Snrs. Subscriptores que quizerem vir ver a extração." - Diário do Rio de Janeiro - 11 de outubro de 1824

Além da venda de livros, Plancher foi responsável por grande parte da produção de panfletos políticos, do periódico Spectador Brasileiro e da Revista Brasileira das Sciencias, Artes e Indústrias, bem como do Jornal do Commercio. É interessante apontar que nem todos os leitores dos periódicos publicados por Plancher estavam satisfeitos com o serviço. Encontramos em duas publicações do Diário do Rio de Janeiro reclamações sobre as ideias ofensivas "ao belo sexo"165 e sobre a irregularidade da publicação do Spectador. ${ }^{166}$

Plancher anunciou no dia 13 de abril a abertura de um gabinete de leitura, onde livros poderiam ser alugados. Neste mesmo anúncio, ele procura por livros variados. O valor da fiança de livros equivalia ao mesmo preço dos 4 volumes da obra de Daniel Defoe, Robinson Crusoé.

"Plancher Impressor Livreiro, rua dos Ourives N. 60, participa ao publico, que
elle abrio hum gabinete de Leitura. O Preço da subscripção mençal he de
2400 réis pago adiantado, dando-se 4000 rs. de fiança pelos livros. Elle
compra todos os livros novos, e que tenhão algum uso, mais que sejão obras
completas; encarrega-se de todas as commissões quer para a França, quer
para a Inglaterra O Público achará sempre em sua casa hum sortimento de
muito bons livros, com superior encadernação, e o Annuario Historico
Brasilense." - Diário do Rio de Janeiro-13 de abril de 1824

${ }^{165}$ Diário do Rio de Janeiro, 30 de setembro de 1824.

${ }^{166}$ Diário do Rio de Janeiro, 3 de dezembro de 1824. 
Em 1826, Plancher anuncia as obras de Walter Scott em sua casa, já no N. 96 da Rua do Ouvidor.

Em 1830, ele vende os livros do Gabinete de Leitura para seu antigo sócio Cremière:

"J. V. Cremière, livreiro, rua dos Ourives n. 86 tem a hora de participar ao
respeitável Publico, que por ajuste feito com o Sr. P. Plancher, acaba de
enriquecer o seu gabinete de leitura, com todos os livros que pertencião ao
gabinete do mesmo Plancher; e espera que pela boa escolha, e grande
variedade não só de livros em Portuguez, como em Francez: ele satisfará a
todos os que quiserem honrar com suas assignaturas" - Diário do Rio de
Janeiro - 23 de novembro de 1830

Mesmo tendo vendido os livros de seu Gabinete de Leitura, Plancher continua a anunciar obras que "sahirão a luz" e os jornais de sua tipografia. Seu filho, Emílio SeignotPlancher trilhou o mesmo caminho.

Podemos afirmar que ele foi um dos estrangeiros que dominaram o cenário editorial do país. Plancher trabalhou como impressor até vender sua firma para Júnio Constâncio de Villeneuve e Réol-Antoine Mougenot em 1832.

Já o livreiro escocês que trabalhou na mesma rua, David Carfrae, não teve o mesmo sucesso de Plancher. O livreiro de Edimburgo trabalhou entre 1824 e 1825, quando declarou falência e retornou à sua cidade natal. No seu estoque, podíamos encontrar romances ingleses:

David Carfrae proximamente chegado de Edimburgo, faz sciente ao respeitavel Publico que na rua do Ouvidor N. 110, tem para vender hum surtimento de Livros, principalmente na Lingua Ingleza, constando varios Auctores nas Sciencias da Medicina, Chimic, Historia, Geografia, \&c., Viagens e todas as Novellas modernas, e obra Poética, incluindo as de Lord Byron, Sir Walter Scott southeza huma variedade de Commedias, 
Entremezes, livros de primeiras letras, tem tambem hum surtimento de livros para contas, papel, pennas, obreias, lacre, tudo que se há de vender por preços modicos e como pertende receber continuadamente de Inglaterra todas as obras modernas, tanto nas differentes linguas de Europa, como a Ingleza; espera merecer o patrocínio dos amantes da literatura. Diário do Rio de Janeiro - 6 de agosto de 1824

No seu anúncio de falência, os administradores dos bens de Carfrae relatam que os livros de seu acervo eram principalmente no idioma inglês e que os assinantes deveriam entregar os livros pertencentes à livraria a Guilherme Binns.

Foi também na Rua do Ouvidor que o primeiro alfarrabista do Rio de Janeiro se instalou: Albino Jordão. Na Rua do Ouvidor, na casa térrea $n^{\circ}$. 138, encontrava-se a loja de Albino Jordão. Segundo Joaquim Manuel de Macedo, tratava-se de um livreiro cego e surdo que contava com dois ajudantes e vendia livros usados a preços acessíveis e foi considerado o primeiro alfarrabista da cidade do Rio de Janeiro. Segundo Macedo, ${ }^{167}$ quando seus funcionários não podiam atender os clientes da loja, Jordão colocava uma buzina na sua orelha para escutar o pedido, e, graças a sua memória prodigiosa, rapidamente localizava o volume pedido em suas estantes.

De acordo com Macedo, o alfarrabista Albino Jordão dizia ao dono da loja de perfumarias vizinha de sua loja:

"Você adorna as cabeças por fora, e eu as adorno por dentro; creio que sou mais útil, mas você tem mais cabeças a adornar."168

Assim como Plancher e Albino Jordão, a livraria de Campos Bellos \& Porto também comprava livros de segunda-mão e os vendia em sua loja na Rua do Ouvidor, $\mathrm{n}$. 75 na década de 20. Em 1822, o sócio Manoel Joaquim dos Santos Porto deixa a "Cidade

\footnotetext{
${ }^{167}$ MACEDO, Joaquim Manuel de. Memórias da Rua do Ouvidor. Brasília: Editora Universidade de Brasília, 1988, pág.108.

${ }^{168}$ Idem, pág. 107.
} 
a procurar milhoras de saúde ${ }^{169 ",}$, deixando o sócio Pedro Antonio de Campos Bellos como único responsável pelo estabelecimento. ${ }^{170}$ Campos Bellos então negociava bolas de bilhar, livros religiosos, de direito, cartilhas, mapas, papéis e bilhetes de rifas. Em 1827, anuncia Robinson Crusoé e em 1830, Robinson Crusoe, Saint Clair das Ilhas e Alberto ou os Desterrados de Strathnavern. A partir de 1831, quem publica os anúncios é sua viúva.

\section{Rua dos Latoeiros}

O nome desta rua foi dado devido as diversas oficinas de latoeiros e fundidores. Foi nesta rua em que em maio de 1789 Joaquim José de Silva Xavier foi preso.

No século XIX, em especial na segunda metade, tornou-se conhecida pela presença de vários jornais, cafés e livrarias, rivalizando com a rua do Ouvidor.

Foi ali que o francês Eduardo Laemmert estabeleceu sociedade com o português Souza, representante de J. P. Aillaude e abriram uma livraria em 1828 no n. 88 . O estabelecimento fica sendo conhecido como Livraria Laemmert. Vendiam modinhas para piano, o jornal Le Courrier du Brésil, dicionários, cartilhas, romances, obras de referência de medicina, direito ${ }^{171}$ e comércio. Em um dos seus anúncios, publica que as obras eram de "grande interesse novamente chegadas de Pariz" ${ }^{172}$. O público poderia encontrar livros novos e usados, artigos de papelaria e obras de Walter Scott ${ }^{173}$. Eduardo Laemmert alcança tamanho sucesso no Rio de Janeiro que, em 1835, viaja para a Europa para buscar seu irmão Heinrich.

${ }^{169}$ Diário do Rio de Janeiro, 11 de setembro de 1822.

${ }^{170}$ Diário do Rio de Janeiro, 20 de março de 1822.

${ }^{171}$ Em um dos anúncios publicados, Laemmert afirma que "tem a honra de anunciar ao respeitável Publico, que possuem na sua livraria, entre huma grande escolha de livros modernos em todas as sciencias e artes, também as obras seguintes necessárias para os Cursos Juridicos de S. Paulo, e Pernambuco" em Diário do Rio de Janeiro, 3 de fevereiro de 1831. O anúncio nos dá uma evidência de que parte da sua clientela era formada por estudantes de direito.

172 Diário do Rio de Janeiro, 20 de agosto de 1830.

${ }^{173}$ Diário do Rio de Janeiro, 06 de setembro de 1826. 


\section{Rua dos Ourives}

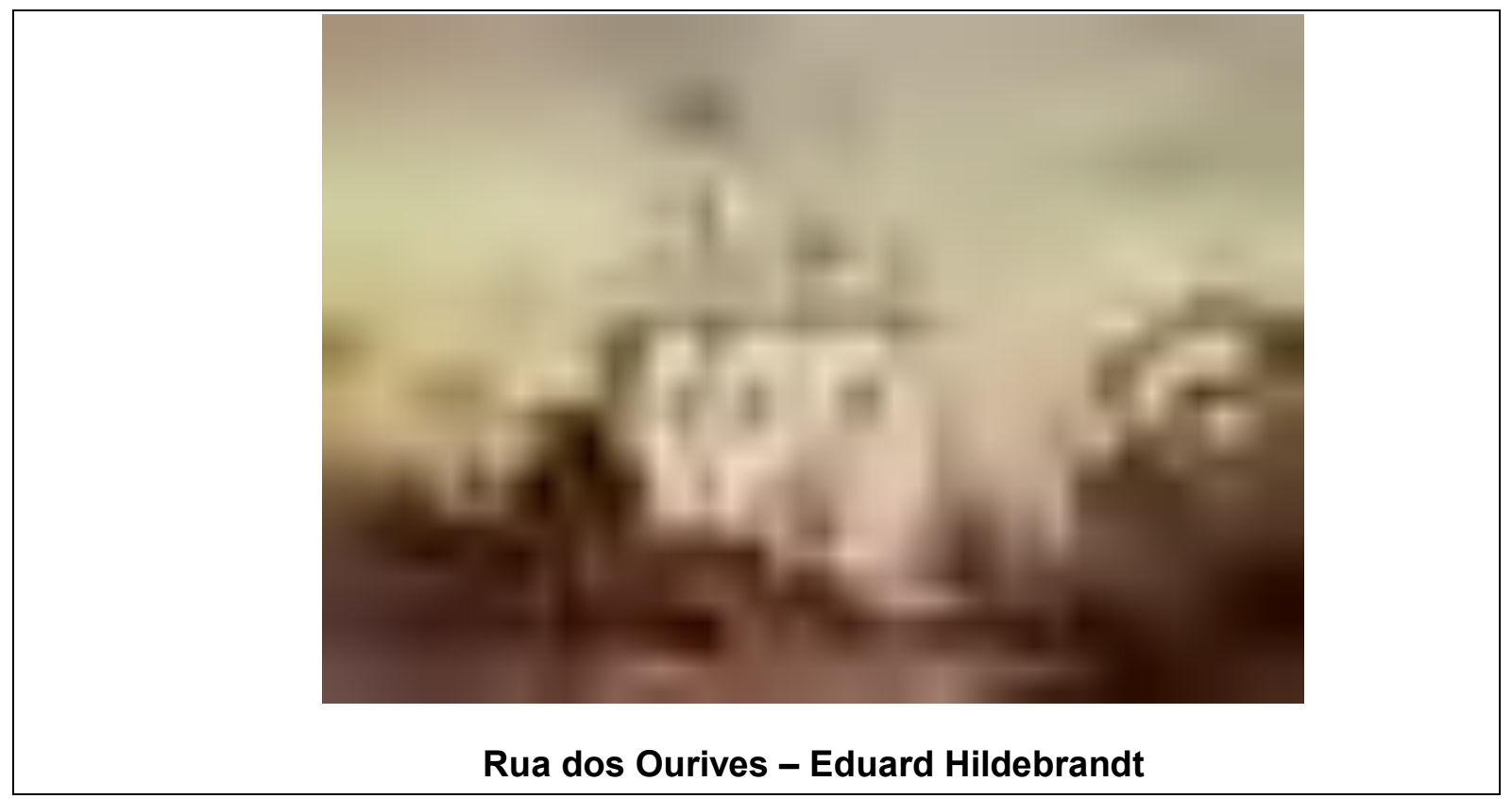

Quando chegou da França, Justin Victor Cremière associou-se a Pierre Seignot Plancher. Quando a sociedade foi desfeita em 1824, Cremière instalou-se na Rua dos Ourives N. 86, onde morava no primeiro andar.

Cremière foi um livreiro inovador, ofertando livros, canivetes, tinteiros, cartas para jogar, papel de música e oferecendo um gabinete de leitura. Entre 1829 e 1830, anunciou as obras Saint Clair das Ilhas, Tom Jones, Gulliver's travels e Amanda e Oscar.

\section{Rua da Quitanda}

A livraria de Paulo Martin funcionava no n. 34. Os anúncios de romances ingleses na Gazeta do Rio de Janeiro indicavam esta loja. Paulo Agostinho Martin Filho era filho de Paul Martin, um dos mais importantes livreiros franceses estabelecidos em Lisboa no século XVIII.

Paulo Martin Filho mudou-se para o Brasil em 1799 acompanhado pelo livreiro Francisco Rolland. Paulo Martin Filho mudou-se para o Rio de Janeiro para trabalhar 
como caixeiro de João Roberto Bourgeois ${ }^{174}$. Como Paulo Martin havia sido formado na loja bem sucedida do pai em Lisboa, ele possuía um conhecimento do mercado livreiro muito superior se comparado aos negociantes brasileiros de livros. Tal conhecimento o levou a ter exclusividade na venda e subscrição da Gazeta do Rio de Janeiro, o primeiro jornal do Rio de Janeiro. Sua loja então é anunciada nos periódicos como loja da Gazeta. Em 1822, muda-se para a rua dos Pescadores, 14 e passa o seu negócio ao seu caixeiro João Baptista Bompard.

Próxima à loja da Gazeta, "defronte da Igreja dos Terceiros do Carmo", encontrava-se a loja de Mandillo a partir da primeira década oitocentista. Manoel Mandillo associou-se a José Borges de Pinho em 1814. Anúncios da loja de Mandillo foram comuns até a década de 30. A loja oferecia livros diversos até que, em 1821, D. Maria Roza de Oliveira, mulher de Manoel Mandillo anuncia que vendeu a parte do falecido marido a Francisco Antonio da Silva, designado em 20 de julho de 1820 como "Livreiro do Conselho da Real Fazenda e avaliador de Livros" no inventário de Antonio Martins Bandeira $^{175}$.

Considerando as condições possíveis de difusão de livros entre 1808 e 1830, elegi dois eixos do ciclo de vida de romances ingleses: os importadores e os vendedores. Partindo da hipótese de que os negociantes de livros poderiam ser os importadores de romances, e, consequentemente, os responsáveis pelas escolhas de quais romances ingleses seriam oferecidos, procurei cruzar os dados dos negociantes encontrados em anúncios de romances ingleses e as listas de requerimento de liberação de livros da Alfândega. Para tanto, compilei uma lista de anunciantes de romances ingleses para traçar características em comum desse grupo e esboçar o possível alcance de suas lojas. O estudo prosopográfico destes negociantes foi organizado de acordo com as localizações geográficas de suas lojas nesta última parte da dissertação e nos auxilia a

\footnotetext{
174 NEVES, Lúcia Maria Bastos P. Trajetórias de Livreiros no Rio de Janeiro: uma revisão historiográfica: João Roberto Bourgeois e Paulo Martin: livreiros franceses no Rio de Janeiro, no início do oitocentos. X Encontro Regional da ANPUH, 2002 (disponível em www.rj.anpuh.org/resources/rj/.../Neves\%20Lucia\%20M\%20B\%20P.doc). Ultimo acesso em outubro de 2013.

${ }^{175}$ ABREU, Márcia. Os lugares dos livros - comércio livreiro no Rio de Janeiro joanino. Floema Ano III, n. 5 A, p. 7-30, out. 2009 (Disponível em http://periodicos.uesb.br/index.php/floema/article/viewFile/127/291) Ultimo acesso em outubro de 2013.
} 
identificar os diferentes tipos de negociantes de livros: comerciantes não especializados, firmas de leilões e livreiros.

Os romances ingleses também passavam pelas mãos de firmas estrangeiras responsáveis pelo transporte e documentação da Alfândega. Ao cruzar os dados da Mesa do Desembargo do Paço com os periódicos estudados, encontramos os nomes de leiloeiros e administradores de bens como Lazan e Vial, Freeze e Blackenhagen, Bourdon \& Fry, Carlos Durand e George Brittain. Estes comerciantes não especializados em livros foram parte essencial do trajeto percorrido por romances de Scott, Roche, Radcliffe, Fielding, Richardson, Defoe, Swift e Sterne e, por esta razão, precisam ser destacados no estudo da história do livro no Rio de Janeiro.

\section{Requerentes leiloeiros e importadores de produtos diversos}

Ambrozio Bourdon

(Bourdon \& Fry)

Carlos Durand $\quad$ Carlos Robillard

Lozan Vial e cia.

Florêncio de
Macedo Pereira

Freese \& Blancken

Izabella Morice

Requerentes de
liberação de
livros para
comercialização
no Rio de Janeiro

Henrique Miller

Joze Borges de Pinho (a pedido de Manoel Mandillo)

Pierre Constant Dalbin

\section{Requerentes de liberação de livros a serem enviados para outras regiões}
Daniel Pedro Muller (para São Paulo)

Domingos Jozé de Araujo Basto (para Porto Alegre)

Jeronimo Gonçalves Guimarães (para a Bahia a pedido de Manoel Antonio da Silva Serva)

Joze Bernardino de Sena (para São Paulo)
Jorge Brittain João Bonneille

Joze de la Brosse Joaquim Pereira de Almeida 


\author{
Jose Antonio Vieira \\ de Carvalho \\ Matheus Buchanan \\ Pedro Affonso de \\ Carvalho
}

Ao cruzarmos a lista de comerciantes envolvidos com a venda de romances ingleses com a de requerentes de liberação destas obras nos arquivos da Mesa do Desembargo do Paço, esperávamos encontrar os mesmos nomes. Entretanto, a maior parte dos requerentes de liberação de romances ingleses era de estrangeiros que traziam suas bibliotecas particulares para seus usos, como se pode observar na tabela acima.

Como pode-se notar, a presença de estrangeiros trazendo títulos diferentes de romances ingleses é maior do que a de comerciantes especializados em venda de livros. O afluxo de europeus chegados ao Rio de Janeiro trazia novos costumes, novas necessidades e nova oferta de romances ingleses. No primeiro capítulo da dissertação, explicamos o porquê da atração dos estrangeiros com relação ao Brasil: era uma terra de oportunidades. A partir da abertura dos portos, aumentou-se a facilidade da entrada de produtos europeus até então desconhecidos ao público do Rio de Janeiro. A Inglaterra aproveitou a chance para explorar este novo nicho de consumidores. Gastão Cruls descreve que até mesmo produtos inusitados foram importados nesta época. ${ }^{176} \mathrm{De}$ acordo com Manchester, "Contact with the outside world awakened the torpid colony: new people, new capital and ideas entered"177. O Rio de Janeiro funcionava como centro de reverberação cultural. Os romances ingleses, importados por livreiros bem sucedidos que já haviam trabalhado neste ramo na Europa, ali aportavam como "novamente chegados" da Inglaterra, França e Portugal. Encontramos também casos de livreiros que importavam para vender na Bahia, São Paulo ou Sul do país.

\footnotetext{
${ }^{176}$ Um carregamento de patins para neve, fogões para calefação interna, bacias de cobre para aquecimento de camas e cobertores de lã foram enviados da Inglaterra e, ainda sim, de diferentes maneiras, aproveitados. CRULS, G. Aparência do Rio de Janeiro. Rio de Janeiro: Livraria José Olympio Editora, 1952. p. 244

177 A partir do contato com o mundo exterior, a colônia foi acordada: novo povo, nova capital e ideias entraram" in: MANCHESTER, A. K. British Preeminence in Brazil: its rise and decline. New York: Octagon Books, 1972, p. 72. (Versão livre)
} 
A hipótese de que os negociantes de romances ingleses eram também o os responsáveis pelos requerimentos de liberação de livros da Alfandega mostrou-se parcialmente errada, visto que a importação de títulos foi distribuída em grupos com objetivos diferentes: uso próprio, venda para lojas ou leilões, comercialização em lojas especializada e envio para outras regiões.

O primeiro grupo de requerentes para uso pessoal é um importante eixo no início do ciclo de vida dos romances ingleses. Juízes, advogados, proprietários de terras, donos de botica, professores e religiosos formaram este grupo que importou e auxiliou na propagação dos romances ingleses no Rio de Janeiro. Como já apontado no embasamento teórico da introdução da dissertação, Darnton explica que o circuito de comunicação do livro "runs full cycle": estes possíveis leitores influenciam as escolhas dos negociantes que importam livros para a venda, assim como a oferta de livros também pode ter influenciado os leitores fluminenses.

As escolhas dos títulos a serem importados ou anunciados também variaram quando comparamos as listas apresentadas no primeiro e no segundo capítulo. Se obras dos autores como Daniel Defoe, Walter Scott, Laurence Sterne, Samuel Richardson, Henry Fielding e Jonathan Swift foram constantes nos dois tipos de documentos historiográficos, outros autores relevantes em relação à história do Romance foram encontrados ora em um, ora em outro. Por exemplo, encontramos uma menção das obras de Jane Austen e Mary Shelley em requerimentos de liberação de livros, porém, nenhuma vez estas autoras foram citadas nos anúncios da Gazeta do Rio de Janeiro e do Diário do Rio de Janeiro no período em questão. Por outro lado, Elizabeth Helme e Regina Maria Roche são citadas diversas vezes em anúncios dos periódicos estudados, porém suas obras não são documentadas na Mesa do Desembargo do Paço. Podemos levantar a hipótese de que estas obras poderiam ter chegado por meio de contrabando, ou passaram despercebidas pelo responsável por checar as caixas de livros. 


\section{Considerações Finais}

\section{"Novellas modernas e de bom gosto, que se achão nas lojas..."}

Nos capítulos anteriores, podemos constatar por meio da análise dos documentos da Mesa do Desembargo do Paço que o Rio de Janeiro era um centro de reverberação do comércio de romances ingleses no início do século XIX. Do Rio de Janeiro, os romances seriam enviados para Rio Grande do Sul, São Paulo e Bahia. Com a ajuda dos anúncios dos jornais Gazeta do Rio de Janeiro e Diário do Rio de Janeiro, completamos parte do quadro de onde os romances ingleses eram vendidos e negociados e quem eram os responsáveis por tal comércio.

Para melhor compreender o caminho dos romances ingleses no Rio de Janeiro no início do século XIX, foi necessário refletir sobre como as mudanças trazidas pela vinda da Corte afetaram o comércio fluminense. A instalação de uma Corte real e adequada aos padrões dos novos residentes no Rio de Janeiro exigia novos projetos arquitetônicos variados, como construção de calçadas, aterros sanitários, iluminação de ruas, novas fontes públicas, um sistema eficiente de esgoto e estradas e pontes para ligar o centro da cidade às vizinhanças próximas, e o estabelecimento de instituições identificadas com a cultura da monarquia portuguesa. ${ }^{178} \mathrm{Em} \mathrm{1808,} \mathrm{o} \mathrm{Rio} \mathrm{de} \mathrm{Janeiro} \mathrm{já} \mathrm{possuía} \mathrm{"71} \mathrm{ruas,} 27$ becos, 7 travessas, 12 largos, 3 campos, 5 ladeiras e 3 caminhos" ${ }^{179}$. Nas palavras de Carlos G. Mota, "a vinda da Corte portuguesa em 1808 já alterara substancialmente o metabolismo da vida da colônia" ${ }^{180}$. Observou-se o afluxo de

\footnotetext{
178 SCHULTZ, K. Versalhes Tropical: Império, Monarquia e a Corte Real Portuguesa no Rio de Janeiro, 1808 - 1821. Rio de Janeiro: Civilização Brasileira, 2008, p. 161.

${ }^{179}$ RIOS FILHO, Adolfo Morales de los. O Rio de Janeiro Imperial. Rio de Janeiro: TopBook, 2002, p.37.
}

${ }^{180}$ MOTA, C. G. 1822: Dimensões. São Paulo, Editora Perspectiva, 1972, p. 60. 
comerciantes, artistas, cientistas e profissionais de mão de obra especializada. A população aumentava de 60 mil para 150 mil no Rio de Janeiro de $1808 .{ }^{181}$ Os comerciantes que ali se instalam utilizam os anúncios de jornais como meio de propaganda de seus produtos e serviços. É por meio destes anúncios que descobrimos a quem os leitores da época deveriam recorrer para obterem romances ingleses. O Rio de Janeiro do início do século XIX era uma terra de possibilidades e expansão. $O$ número de negociantes cresce com 0 estabelecimento dos estrangeiros e seus armazéns. Conforme as informações coletadas em anúncios e estudiosos do período em questão, o destino de compradores em busca de romances ingleses pode ser determinado em ruas do centro do Rio de Janeiro.

Apresentei a pesquisa quantitativa dos documentos da Mesa do Desembargo do Paço, bem como dos anúncios de dois periódicos de extensa publicação (Gazeta do Rio de Janeiro e Diário do Rio de Janeiro), que nos permitiu esboçar um panorama do alcance dos romances ingleses no Rio de Janeiro de 1808 a 1830 e sublinhar quem eram os responsáveis pelo funcionamento do comércio livreiro.

Os requerimentos de liberação de livros da Mesa do Paço do Rio de Janeiro nos apresentaram nomes de estrangeiros que comercializavam não somente livros, mas também importavam produtos variados, como chás, tecidos e papéis, para suas próprias lojas, de encomendas ou para leilões.

E ao longo dos anos de publicação, a Gazeta do Rio de Janeiro nos forneceu grande material com relação ao início da circulação de romances no Rio de Janeiro. É por meio de seus anúncios que localizamos os primeiros livreiros na cidade e conseguimos apontar as obras mais citadas.

${ }^{181}$ CUNHA, P. O. C. "A fundação de um império liberal" in HOLLANDA, Sérgio Buarque de. (org.) - História geral da civilização brasileira, São Paulo, DIFEL, 1962, p.2. O Brasil Monárquico, v. 1: O processo de emancipação, p. 153. 
O Diário do Rio de Janeiro nos auxiliou pela variedade de anúncios e anunciantes. Infelizmente, alguns requerentes e negociantes citados ao longo do trabalho continuam como incógnitas por falta de documentos historiográficos que forneçam mais dados sobre seus papéis no comércio livreiro fluminense. Darnton diz que o estudo da História do Livro nos lembra mais uma floresta tropical do que um campo ${ }^{182}$. Esta imagem não só traduz a diversidade de disciplinas que lidam com o processo de reflexão sobre a circulação do livro, mas com a complexidade e quase impossibilidade de atingir a sua totalidade.

Como desdobramento desta dissertação, pretende-se aumentar o escopo de informações sobre os responsáveis pela circulação de romances ingleses no Rio de Janeiro, com a finalidade de estabelecer melhores ligações entre os interesses destes comerciantes e a circulação das idéias vinculadas a estes romances.

182 DARNTON, Robert. "What is the History of Books?" 1982 in http://dash.harvard.edu/handle/1/3403038., acesso em Janeiro de 2014. 


\section{Mesa do Desembargo do Paço}

As informações sobre os romances ingleses coletadas nos documentos encontrados da Mesa do Desembargo do Paço no Arquivo Nacional foram organizadas em tabelas de acordo com as caixas em que se encontravam. 


\section{Caixa 168}

\begin{tabular}{|c|c|c|c|c|}
\hline requerente & data & ano & Obra & autor \\
\hline Bourdonn e Fry & 30/ago & 1819 & Mansfield Park & Austen, Jane \\
\hline Bourdonn e Fry & 30/ago & 1819 & Brighton; or, The Steyne. A satirical novel & Brown, Thomas \\
\hline Bourdonn e Fry & 30/ago & 1819 & Tales & Crabbe, George \\
\hline Ambrozio Bourdon & 20/mai & 1816 & Robinson Crusoe & Defoe, Daniel \\
\hline Bto Swenhbergh & 4/mai & 1818 & Vivian & Edgeworth, Maria \\
\hline Bto Swenhbergh & 4/mai & 1818 & The absentee & Edgeworth, Maria \\
\hline Bto Swenhbergh & 4/mai & 1818 & Sidney & Edgeworth, Maria \\
\hline Bto Swenhbergh & 4/mai & 1818 & Vivian & Edgeworth, Maria \\
\hline Bto Swenhbergh & 4/mai & 1818 & Scenes de la vie du grand monde & Edgeworth, Maria \\
\hline Bto Swenhbergh & 4/mai & 1818 & Madame de Fleury & Edgeworth, Maria \\
\hline Bourdonn e Fry & 30/ago & 1819 & St. Leon: a tale of the sixteenth century & Godwin, William \\
\hline Ambrozio Bourdon & 3/out & 1816 & The Vicar of Wakefield & Goldsmith, Oliver \\
\hline Ambrozio Bourdon & 14/nov & 1816 & The Vicar of Wakefield & Goldsmith, Oliver \\
\hline Ambrozio Bourdon & 20/mai & 1816 & Alberto, ou o deserto de Strathnavern & Helme, Mrs. Elizabeth \\
\hline Ambrozio Bourdon & 20/mai & 1816 & Pamela or, Virtue Rewarded & Richardson, Samuel \\
\hline
\end{tabular}




\begin{tabular}{|l|r|r|l|l|} 
Bto Swenhbergh & $4 /$ mai & 1818 & Pamela or, Virtue Rewarded & Richardson, Samuel \\
\hline Ambrozio Bourdon & $3 /$ out & 1816 & Clermont & $\begin{array}{l}\text { Roche, Regina Maria } \\
\text { Roche }\end{array}$ \\
\hline Ambrozio Bourdon & $20 / \mathrm{mai}$ & 1816 & Clermont & $\begin{array}{l}\text { Roche, Regina Maria } \\
\text { Roche }\end{array}$ \\
\hline Ambrozio Bourdon & $20 / \mathrm{mai}$ & 1816 & A Sentimental Journey Through France and Italy & Sterne, Laurence \\
\hline Ambrozio Bourdon & $20 / \mathrm{mai}$ & 1816 & Sterne's Lettres & Sterne, Laurence \\
\hline Bourdonn e Fry & $30 / a g o$ & 1819 & Gentleman & Sterne, Laurence \\
\hline Bourdonn e Fry & $30 /$ ago & 1819 & A Sentimental Journey Through France and Italy & Sterne, Laurence \\
\hline Ambrozio Bourdon & $20 /$ mai & 1816 & Gulliver's Travels & Swift, Jonathan \\
\hline
\end{tabular}

\section{Caixa 169}

\begin{tabular}{|l|c|c|c|c|}
\hline requerente & data & ano & Obra & Autor \\
\hline
\end{tabular}




\begin{tabular}{|c|c|c|c|c|}
\hline Carlos Durand & $8 / a b r$ & 1816 & Robinson Crusoe & Defoe, Daniel \\
\hline Carlos Durand & $24 / \mathrm{mai}$ & 1819 & Robinson Crusoe & Defoe, Daniel \\
\hline Claudio João Baptista Loyseleur & $5 /$ nov & 1818 & Robinson Crusoe & Defoe, Daniel \\
\hline Domingos Joze de Araujo Basto & 4/ago & 1816 & Robinson Crusoe & Defoe, Daniel \\
\hline Florencio alb de Macedo Pereira & 15/mai & 1820 & Robinson Crusoe & Defoe, Daniel \\
\hline Francisco Ignacio de Souza Queiroz & 19/jun & 1818 & Robinson Crusoe & Defoe, Daniel \\
\hline Jeronimo Gonçalvez Guimaraes & 15/dez & 1817 & Robinson Crusoe & Defoe, Daniel \\
\hline Carlos Robillard & 19/out & 1820 & The History of Tom Jones, a Foundling & Fielding, Henry \\
\hline Claudio João Baptista Loyseleur & $5 /$ nov & 1818 & The History of Tom Jones, a Foundling & Fielding, Henry \\
\hline Claudio João Baptista Loyseleur & $5 /$ nov & 1818 & The History of Tom Jones, a Foundling & Fielding, Henry \\
\hline Francisco Ignacio de Souza Queiroz & 19/jun & 1818 & The History of Tom Jones, a Foundling & Fielding, Henry \\
\hline Francisco Luiz Saturnino & 8/mai & 1820 & The History of Tom Jones, a Foundling & Fielding, Henry \\
\hline Freese e Blancken & 30/ago & 1810 & Fielding's works & Fielding, Henry \\
\hline Francisco Ignacio de Souza Queiroz & 19/jun & 1818 & Les Choses telles qu'elles sont, ou Les Aventures de Caleb Williams & Godwin, William \\
\hline Carlos Durand & 12/jul & 1819 & The Vicar of Wakefield & Goldsmith, Oliver \\
\hline Carlos Durand & 9/jun & 1817 & Alberto, ou o deserto de Strathnavern & Helme, Mrs. Elizabeth \\
\hline Francisco Ignacio de Souza Queiroz & 19/jun & 1818 & Alberto, ou o deserto de Strathnavern & Helme, Mrs. Elizabeth \\
\hline Daniel Pedro Muller & $27 / a b r$ & 1817 & Pamela or, Virtue Rewarded & Richardson, Samuel \\
\hline
\end{tabular}




\begin{tabular}{|c|c|c|c|c|}
\hline Domingos Joze de Araujo Basto & 4/ago & 1816 & Pamela or, Virtue Rewarded & Richardson, Samuel \\
\hline Francisco Ignacio de Souza Queiroz & 19/jun & 1818 & Celestine & Smith, Charlotte Turner \\
\hline Henrique Miller & $7 /$ set & 1818 & elegancias de sterne & Sterne, Laurence \\
\hline Izabella Morice & 19/jul & 1810 & obras de sterne & Sterne, Laurence \\
\hline Joao Bonneille & 29/jan & 1821 & Beauties of Sterne & Sterne, Laurence \\
\hline Francisco Luiz Saturnino & 8/mai & 1820 & Gulliver's Travels & Swift, Jonathan \\
\hline Freese e Blancken & 30/ago & 1810 & Gulliver's Travels & Swift, Jonathan \\
\hline Jeronimo Gonçalvez Guimaraes & 15/dez & 1817 & Gulliver's Travels & Swift, Jonathan \\
\hline
\end{tabular}

\section{Caixa 170}

\begin{tabular}{|l|r|r|l|l|}
\hline \multicolumn{1}{|c|}{ Requerente } & data & ano & \multicolumn{1}{|c|}{ Obra } & Autor \\
\hline Joze Hobson & $30 /$ ago & 1819 & The Adventures of an Ostrich Feather of Quality & Anônimo \\
\hline Joze Hobson & $5 /$ jul & 1819 & The Adventures of an Ostrich Feather of Quality & Anônimo \\
\hline Joze Hobson & $30 /$ ago & 1819 & Brighton; or, The Steyne. A satirical novel & Brown, Thomas \\
\hline Joze Hobson & $5 /$ jul & 1819 & Brighton; or, The Steyne. A satirical novel & Brown, Thomas \\
\hline
\end{tabular}




\begin{tabular}{|c|c|c|c|c|}
\hline Manoel Antonio da Silva Serva & $30 /$ set & 1818 & Cecilia & d'Arblay, Madame (Fanny Burney) \\
\hline Joaquim Pereira de Almeida e C. & $12 /$ mar & 1817 & Robinson Crusoe & Defoe, Daniel \\
\hline Joze de la Brosse & $8 / a b r$ & 1818 & Robinson Crusoe & Defoe, Daniel \\
\hline Manoel Antonio da Silva Serva & 15/jul & 1820 & Robinson Crusoe & Defoe, Daniel \\
\hline Joze Bernardino de Sena & $29 / \mathrm{mar}$ & 1819 & Moral Tales & Edgeworth, Maria \\
\hline Joze Bernardino de Sena & 29/mar & 1819 & Popular Tales & Edgeworth, Maria \\
\hline Joze Bernardino de Sena & 29/mar & 1819 & The modern Griselda' & Edgeworth, Maria \\
\hline Joze Bernardino de Sena & $29 / \mathrm{mar}$ & 1819 & Essay on Irish Bulls & Edgeworth, Maria \\
\hline Joze Bernardino de Sena & $29 /$ mar & 1819 & Comic Dramas & Edgeworth, Maria \\
\hline Joze Bernardino de Sena & $29 /$ mar & 1819 & Leonora & Edgeworth, Maria \\
\hline Joze Bernardino de Sena & 29/mar & 1819 & Harrington & Edgeworth, Maria \\
\hline Joze Bernardino de Sena & $29 / \mathrm{mar}$ & 1819 & Harrington & Edgeworth, Maria \\
\hline Joze de la Brosse & 15/abr & 1819 & Emilie de Coulanges & Edgeworth, Maria \\
\hline Joze Bernardino de Sena & $29 / \mathrm{mar}$ & 1819 & Fielding's works & Fielding \\
\hline Joze Bernardino de Sena & $29 / \mathrm{mar}$ & 1819 & Things as They Are; or, The Adventures of Caleb Williams & Godwin, William \\
\hline Joze Bernardino de Sena & $29 /$ mar & 1819 & Things as They Are; or, The Adventures of Caleb Williams & Godwin, William \\
\hline Joze Bernardino de Sena & $29 / \mathrm{mar}$ & 1819 & St. Leon: a tale of the sixteenth century & Godwin, William \\
\hline Joze Bernardino de Sena & $29 /$ mar & 1819 & works & Goldsmith, Oliver \\
\hline
\end{tabular}




\begin{tabular}{|c|c|c|c|c|}
\hline Joze Bernardino de Sena & $29 /$ mar & 1819 & The Vicar of Wakefield & Goldsmith, Oliver \\
\hline Joze Hobson & $5 / \mathrm{jul}$ & 1819 & The Vicar of Wakefield & Goldsmith, Oliver \\
\hline $\begin{array}{l}\text { Jose Antonio Vieira de } \\
\text { Carvalho }\end{array}$ & $27 / a b r$ & 1820 & Louisa; or the Cottage of the Moor & Helme, Elizabeth \\
\hline Joze de la Brosse & 15/abr & 1819 & Glovina or the Wild Irish Girl & Owenson, Sydney (Lady Morgan) \\
\hline Joze de la Brosse & 15/abr & 1819 & Glovina or the Wild Irish Girl & Owenson, Sydney (Lady Morgan) \\
\hline Joze Hobson & 30/ago & 1819 & The Life and Adventures of Peter Wilkins, a Cornish Man & Paltock, Robert \\
\hline Joze Hobson & $5 /$ jul & 1819 & The Life and Adventures of Peter Wilkins, a Cornish Man & Paltock, Robert \\
\hline Joze Bernardino de Sena & 29/mar & 1819 & Thaddeus of warsaw & Porter, Jane \\
\hline Joze Bernardino de Sena & $29 /$ mar & 1819 & The History of Sir Charles Grandison & Richardson, Samuel \\
\hline Joze Borges de Pinho & $12 / a b r$ & 1815 & Pamela or, Virtue Rewarded & Richardson, Samuel \\
\hline Jorge Brittian & 3/out & 1818 & Waverley & Scott, Walter \\
\hline Jorge Brittian & 3/out & 1818 & Rob Roy & Scott, Walter \\
\hline Jorge Brittian & 3/out & 1818 & Tales of my Landlord & Scott, Walter \\
\hline Jorge Brittian & 3/out & 1818 & Rob Roy & Scott, Walter \\
\hline Jorge Brittian & 3/out & 1818 & Waverley & Scott, Walter \\
\hline Jorge Brittian & 3/out & 1818 & Tales of my Landlord & Scott, Walter \\
\hline Joze Bernardino de Sena & $29 /$ mar & 1819 & Guy Mannering & Scott, Walter \\
\hline
\end{tabular}




\begin{tabular}{|c|c|c|c|c|}
\hline Joze Bernardino de Sena & $29 /$ mar & 1819 & Rob Roy & Scott, Walter \\
\hline Joze Bernardino de Sena & $29 /$ mar & 1819 & Tales of my Landlord & Scott, Walter \\
\hline Joze Bernardino de Sena & $29 /$ mar & 1819 & Waverley & Scott, Walter \\
\hline Lozan Vial e cia & $27 /$ out & 1817 & The Vicar of Wakefield & Scott, Walter \\
\hline Lozan Vial e cia & $27 /$ out & 1817 & The Vicar of Wakefield & Scott, Walter \\
\hline Joze Bernardino de Sena & $29 /$ mar & 1819 & The adventures of Roderick Random & Smollet, TobiasGeorge \\
\hline Joze Bernardino de Sena & $29 /$ mar & 1819 & Smollet's works & Smollet, TobiasGeorge \\
\hline Joze Bernardino de Sena & 29/mar & 1819 & Roderick the Last of the Goths & Southey, Robert \\
\hline Jorge Brittian & 3/out & 1818 & Oeuvres & Sterne, Laurence \\
\hline Jorge Brittian & $3 /$ out & 1818 & Sterne & Sterne, Laurence \\
\hline Joze Bernardino de Sena & $29 /$ mar & 1819 & A Sentimental Journey Through France and Italy & Sterne, Laurence \\
\hline Joze Bernardino de Sena & $29 /$ mar & 1819 & The Life and Opinions of Tristram Shandy, Gentleman & Sterne, Laurence \\
\hline Lozan Vial e cia & $27 /$ out & 1817 & The sentimental Journey & Sterne, Laurence \\
\hline Joze Bernardino de Sena & $29 /$ mar & 1819 & Gulliver's Travels & Swift, Jonathan \\
\hline Joze Bernardino de Sena & $29 /$ mar & 1819 & Frankenstein; or the modern Prometheus & Wollstonecraft, Mary Shelley \\
\hline
\end{tabular}




\section{Gazeta do Rio de Janeiro}

Os anúncios transcritos seguem a ortografia encontrada nos jornais. Foram coletados nos primeiros meses de pesquisa do mestrado com o intuito de localizar os romances ingleses, bem como os negociantes que os comercializavam. Os romances ingleses e obras mencionadas como "livros ingleses" são destacados na em negrito para facilitar a visualização.

Faz se sabe ao publico que os livros, que se achavao na loja de Manoel mandilo, se passarão para a loja de vidros na rua do ouvidor $n$. 10 de José Borges de pinha, com o rebae dos precos nos que abaixo se declarao - fabulas de phedro, (...) viagens de Henrique wanton, (...) Pámela ${ }^{183}$ (em $8^{\circ} 2$ vol) a 1600 - A mulher feliz dependente do mundo e da fortuna (...) a desgraça da inscontancia (...) historia georgiana (...)

16 de agosto de 1815

Novellas que se achão na loja da Gazeta - Ilha incógnita, 6 vol., com estampas, 4800; - Emma 2 vol., 2:240, - Desgraças da inconstância, 2 vol 2240; mulher feliz dependente do mundo e da fortuna , mathilde ${ }^{184}$, desgraçado napolitano, numa popilio , historia do joven siciliano.

\footnotetext{
${ }^{183}$ RICHARDSON, Samuel. Pamela. 1742.

${ }^{184}$ Esta obra pode ser a tradução de Lady Mathilde (1793) de Elizabeth Inchbald.
} 
Na loja da gazeta se achao as seguines novellas novamente chegadas. - Sophia ou a donzella (...) Luiza, ou o cazal no bosque ${ }^{185}$ (...) etelvina (...) celestina (...)

15 de março de 1817

Na loja da Gazeta se vendem as seguintes novelas. Os amigos rivaes, 1 volume 960. - A Cazinha, 480 - Adelaide, 1 volume 960. - Irma ou as desgraças de huma joven Orphã, 4 volumes 4.800. - Viagens de Guliver ${ }^{186}$, 3 volumes 2.880 - O Novo Guliver 4 volumes 4:000.

9 de abril de 1817

Na loja da Gazeta se acha huma nova Edição da Vida e Aventuras admiráveis de Robinson Crosué ${ }^{187}, 4$ vol. por 4.800 réis; novela que tem merecido geral aceitação.

10 de maio de 1817

na loja da gazeta se acha a nova e engraçada novella, Tom Jones ou o Engeitado ${ }^{188}$, 4 vol. Por 8:640 réis

8 de março de 1820

Na loja da gazeta sea acha o complemento da Historia da infeliz clara harlowe ${ }^{189}$, que são 8 volumes, desde tomo 7 a 15 a 960 reis cada volume, e se vendem separados,e toda obra por 12800 .

\footnotetext{
${ }^{185}$ HELME, Elizabeth. Louisa, or the Cottage on the Moor, 1787.

${ }^{186}$ SWIFT, Jonathan. Gulliver's travels, 1726.

${ }^{187}$ DEFOE, Daniel. The Life and Adventures of Robinson Crusoe, 1719.

${ }^{188}$ FIELDING, Henry. Tom Jones, 1749.

${ }^{189}$ RICHARDSON, Samuel. Clarissa: Or the History of a Young Lady, 1758.
} 


\section{Diário do Rio de Janeiro}

Os anúncios encontrados contando com romances ingleses são escritos abaixo respeitando a ortografia publicada no Diário do Rio de Janeiro. Estão organizados cronologicamente, sendo que os romances ingleses são destacados em negrito. Os anúncios que continham menções a obras inglesas foram também anexados. 


\section{1}

\section{Data}

\section{Junho}

05

COMPRAS

Quem quizer comprar hum bom cavalo, alguns moveis com huma boa Secretaria, commoda, estantes de Livros e Livros Franceses, Ingleses e Portuguezes, dirija-se á rua de Santa Thereza defronte do Regedor.

09 Na Loja de Livros Inglezes $N^{\circ} 25$, rua do Ouvidor restão ainda para vender alguns mais, e bahus fortes cobertos de couro lizo pelo preço regular de $4 \$ 000$ réis cada hum.

\section{Julho}

Na botica do Diario, rua do Quitanda, No 109 se achão para vender as Obras seguintes: O Triunfo da Religião 2 volumes, ( ... ) Ditas de Gil Braz de Santilharia 4 volumes $7 \$ 560$. Noites d'Young 2 volumes $1 \$ 280$. (...)

\section{Setembro}

Hoje 25 do corrente as 11 horas da manhã em caza de Guilherme Lennox N57 rua da Quitanda, se faz leilão de varios Livros Ingleses e Francezes, dos melhores Auctores; tambem moveis (...) 


\section{2}

\section{Janeiro}

Acha-se para vender na rua dos Siganos No24 huma porção de livros, a maior parte Francezes, Latinos e Inglezes de Sciencias, de Medicina, de literatura e de viagens, que o dono carece vender, desejando voltar para a Europa: quem quizer compra-los, dirija-se á dita caza todos os dias depois das 8 horas de manhã até as 2 da tarde. Esta Biblioteca formada para o proprio uso do dono he a escolha dos melhores Authores.

\section{Fevereiro}

Huma pessoa que volta para Europa tem para vender livros de Mathematica, Quimica, Fisica, Medicina, Literatura, História e Viagens, a maior parte Francezas, alguns Latinos, Inglezes, Italianos, e Portuguezes: quem os quizer comprar, dirija-se a rua dos Siganos $N^{\circ} 24$, todos os dias até o 25 de Fevereiro. Cada obra se vende separadamente e por preço muito commodo.

\section{Março}

08

LIVROS A'VENDA

Huma pessoa que volta para Europa tem para vender livros de Mathematica, Quimica, Fisica, Medicina, Literatura, História e Viagens, a maior parte Francezas, alguns Latinos, Inglezes, Italianos, e Portuguezes: quem os quizer comprar, dirija-se a rua dos Siganos $N^{\circ} 24$, todos os dias até o 25 de Fevereiro. Cada obra se vende separadamente e por preço muito commodo.

Quem quizer comprar as obras Francezas e Inglezas seguintes, pode dirigir-se a rua dos Lotoeiros $N^{\circ} 12$, segundo andar. ( ... )

Obras Inglezas: Vida e Viagens do Capitão Cook 2 vol. em 8 ( ... ) Viagens do 
amiral Ansom., à Roda do Mundo 1 vol. em $8^{\circ}$, Obras poéticas de Pope 2 vol em 12., quem desejar aprender as lingoas Ingleza e Franceza, pode fallar na mesma rua dos Lotoeiros $N^{\circ} 12$, segundo andar.

\title{
Maio
}

24

LEILÕES

Leilão hoje 24 do corrente as 11 horas em ponto, de Livros Inglezes com varias classes de Litteratura (...); em casa de Guilherme Lennox N. 150, rua da Quitanda.

Hoje 29 do corrente às 11 horas em ponto, em casa de Guilherme Lennox, N150 rua da Quitanda, se faz leilão de Livros, nos Idiomas, Inglez, Francez, e Latim, em varias claces de literatura; hum aparelho de louça de mesa dourado, e mais generos, por todo o preço.

\section{3}

\begin{abstract}
Abril
NOTÍCIAS PARTICULARES Pede-se ao Sñr Luiz Goularte de Oliveira, segundo e dignissimo ensaiador da casa da Moeda; queira mandar entregar ao Sñr. João da Silva Pinto o $2^{\circ} \mathrm{e}$ $3 z 167$ Tomo das Viagens de Guliver ${ }^{190}$, os quaes se achão em seu poder para assim premitirem circunstancias particulares, e como por outro meio não posso rogar-Ihe; o faço por este Diario.
\end{abstract}

18

COMPRAS

Quem tiver a Obra Pamella ${ }^{191}$, e a queira vender, declare pelo mesmo Diario, onde se deve proenrarar para semelhante compra.

23

COMPRAS

Quem tiver para vender os livros seguintes: obras de Sterne ${ }^{192}$ em Francez; os dois Corneilles, obras de Moriveaux; de Scarron: a Biographie Universal, os

\footnotetext{
${ }^{190}$ SWIFT, Jonathan. Gulliver's trave/s, 1726.

${ }^{191}$ RICHARDSON, Samuel. Pamela. 1742.

${ }^{192}$ STERNE, Laurence.
} 
Homens Ilustres do Plantarque, os Car[...] de La Broyere, e a Biblioteca dos Theatros. Sendo novos, ou pouco usados, procure na rua dos Ourives $N^{\circ} 95$ para tratar do preço delles.

Na rua da Misericórdia N. 10 há para vender por preços commodos hum grande numero de Livros antigos, Portuguezes, Alemães, Inglezes, Hollandezes, Francezes, Dinamarquezes, Russianos, Gregos, Hebraicos e Latinos.

\section{4}

\section{Fevereiro}

05

LIVROS A'VENDA

Quem quizer comprar livros Francezes, Portuguezes, e Inglezes, todos dos melhores Auctores de Marinha, Mathematica, Literatura, Poesia e Viagens; dirija-se a rua dos Ciganos N. 51, depois das 11 horas da manhã até as 3 da tarde.

Quem quizer comprar livros Francezes, Portuguezes, e Inglezes, todos dos melhores Auctores de Marinha, Mathematica, Literatura, Poesia e Viagens; dirija-se a rua dos Ciganos N. 51, depois das 11 horas da manhã até as 3 da tarde.

\section{Maio}

Leilão que faz Thomaz B. Hunt hoje Segunda Feira 10 do corrente, na sua casa N. 135 rua do Ouvidor de huma porção de livros de diversos Idiomas, a saber Inglez, Portuguez, Francez, \&c. e tambem huma grande porçao de casquinha muito rica; o qual será vendido por todo o preço, principiará as 3 horas da tarde. Amanhã Terça feira haverá leilão de fazendas as 11 horas da 
manhã.

Na rua dos Pescadores N.14, se acha a muito estimada obra em Francez, Les Beautés Sterne ${ }^{193}$ fornées des plusiers de ses Lettres et de ses Sermons; des Morceaux les plus touchans \&c. \&. Por $2 U 2$ vol. $8^{\circ}$.

LIVROS A'VENDA Avis à MM. les Officiers de la Marine nationale et etrangere

M. Plancher, imprimeur - libraire, rue des Ourives n. 60, vient de faire l'acquisition de la nouvelle Carte de l'Entrée et Baie de Rio de Janeiro levée par ordre du Governement Bresilien, et publiée à Londres en 1821 par W. Faden, Geopraphe de S. M. le Roi d'Angleterre.

Cette Carte, Qui réunit l'exactitude e la correction à la beauté de l'execution, se vend $4 \$ 000$ reis.

Les amateurs trouveront toujours chez M. Planchez un joli assortiment de livres reliés, tels que la Botanique de J. J. Rosseau, 1 vol. $4^{\circ}$ et [ ] de 65 figure coloriées.

Discours et Rapports à la Chambre des Pairs et des Députés, en 1823, 2 vol. in-8, ornés de cartes et portraits, et faisant suite au choix de rapports.

Guide du Navigateurs dans l'Ocean atlantique, 2 vol. in -8.

L'Histoire de France, par Lacretelle, 6 vol. 8.

Les Guerres de Rekligion, par le méme auteur, 4 vol, in-8.

Dictionnaire de l'Academie, 2 vol. 8.

Dictionnaire italien-français, 2 vol. 8.

Les Lettres Normandes, par Leon Thiessé, 10 vol. .

La Minerve française, par Benjamin Constant, Jai, Joui, Tissot, Pagès, 9 gros

${ }^{193}$ STERNE, Laurence. Beauties of Sterne, 1782. 
volumes, avec portraits.

Recueil de Causes célèbres, 12 vol. 8.

Révolutions de Paris, par Prudhomme, 10 vol. 8. Avec figures.

Voyage à la Recherche de Lapeyrouse, 2 vol. 8 avec un atlas superbe.

Tom Jones ${ }^{194}$, en anglais, 2 vol. ornés de figures.

\section{LEILÕES}

J. J. Dodsworth faz leilão em sua casa N. 399 rua da alfandega ( .. ) tambem livros em differentes Idiomas muitos Inglezes e Francezes, dos melhores Auctores.

Quem quizer comprar as Obras Completas de Walter Scott, em Inglez tendo 52 vol.; procure a casa de João Antonio Ferrisse rua Direita N. 79, aonde se póde ver.

Quem tiver para vender em meio uso livros Francezes, Inglezes, Portuguezes, e Hepanhoes, dirija-se a rua do Rozario N. 20 a Mr. Izidoro Proffessor da Aula.

\section{Agosto}

06

LIVROS A'VENDA

David Carfrae proximamente chegado de Edimburgo, faz sciente ao respeitavel Publico que na rua do Ouvidor N. 110, tem para vender hum surtimento de Livros, principalmente na Lingua Ingleza, constando varios Auctores nas Sciencias da Medicina, Chimic, Historia, Geografia, \&c., Viagens e todas as Novellas modernas, e obra Poética, incluindo as de Lord Byron, Sir Walter Scot southeza huma variedade de Commedias, Entremezes, livros de primeiras letras, tem tambem hum surtimento de livros para contas, papel, pennas, obreias, lacre, tudo que se há de vender por preços modicos e como

${ }^{194}$ FIELDING, Henry. Tom Jones, 1749. 
pertende receber continuadamente de Inglaterra todas as obras modernas, tanto nas differentes linguas de Europa, como a Ingleza; espera merecer o patrocínio dos amantes da literatura.

16

\section{Dezembro}

OBRAS PUBLICADAS

Na loja de livros de João Baptista Bompard, rua dos Pescadores N. 49, sahio á luz: Amanda e Oscar, ou Historia da Família de Deureath ${ }^{195} 8^{\circ} 6$ vol. Por 5U000. O Secretario Filosofo $8^{\circ}$ 960, e Epistola de Manoel Mendes Fogaça dirigida de Lisboa a hum Amigo de sua terra $8^{\circ}$ por 200.

$17-18$

$\varnothing$

20

COMPRAS

Quem tiver as novellas ou contos Orientaes, e os queira vender, noticie por este Diario ainda que sejão uzados, ou vá na rua do Cano N. 149.

$21-22$

$\varnothing$

23

OBRAS PUBLICADAS

Na loja de João Baptista Bompard, rua dos Pescadores, N.49, sahio a luz: o desengano do Mundo, ou Morte de Bonaparte encontrado este na Eternidade hum rancho de Carcundas, por José Daniel Rodrigues da Costa $8^{\circ}$ por 200 réis, na mesma casa se acha Bilhetes de boas festas modernos por preços commodos.

\section{5}

\section{Janeiro}

${ }^{195}$ ROCHE, Maria Regina. The Children of Abbey, 1796. 
David Carfrae N. 110 rua do Ouvidor, tem para vender Epoques Remarquables de L'Histoire Universelle em 5 vol., L'Histoire de La Gréce, Beautés de L'Histoire du Portugal, Oeuvres D'Homére traduites de Grec em 4 vol., Vice des Enfans Célébres 2 vol., Aventures de Robinson Crusoe ${ }^{196}$ em 2 vol., Bibliographie des Jeunes Gens em 4 vol., Le Précepteur des Enfans, e muitas outras obras nas linguas Francezas, e Hespanhola.

\section{Fevereiro}

Sahirão á luz: $01^{\circ} \mathrm{e}^{\circ}$ tomo de huma Tradição Escoceza; Saint = Clair das Ilhas, ou os Desterrados na Ilha da Barra ${ }^{197}$, tradusida do Francez em lingua vulgar, 4 tomos, custo 2U400. Continua a subscrever se para esta obra, nas Seguintes casas: rua da Quitanda N. 41, armazem de musica de Fergunson \& Crockeatt, canto da rua de S. Pedro, loja de livros de João Pedro da Veiga \& Comp. N. 246, dita de Francisco Nicolao Mandillo 249, dita de Francisco Carlos de Vasconcellos, rua dos Pescadores ao sahir para a sua Direita, botica de Estevão Alvez de Magalhães, rua da Alfandega N.8 armarinho de Santos José Rodrigues largo da Carioca N. 4 botica de S. Francisco Xavier, Praça da Constituição, loja de ferragens de José Bernardo de Sá.

\section{Abril}

OBRAS PUBLICADAS

Sahirão á luz: os dous ultimos volumes da Tradição Escoceza = Saint Clair das IIhas, ou os Desterrados na IIha da Barra = traduzida do Francez em quatro volumes. Acha-se a venda esta obra na loja de livros de João Pedro da Veiga \& Comp., rua da Quitanda, canto da de S. Pedro, no armazem de Muzica de Ferguson \& Comp. na mesma rua da Quitanda entre a do Cano e da Cadeia; na botica de Estevão Alves de Magalhães, rua dos Pescadores entre a travessa da Candellaria, e rua Direita, no almarinho de Santos José Rodrigues, rua da Alfandega ao sahir para a rua da Direita, na botica de Francisco Xavier, largo da Carioca, e na loja de ferragem de José Bernardo

\footnotetext{
${ }^{196}$ DEFOE, Daniel. The Life and Adventures of Robinson Crusoe, 1719.

${ }^{197}$ HELME, Elizabeth. St. Clair of the Isles or the Outlaws of the Barra. A Scottish Tradition, 1803.
} 
de Sá na Praça da Constituição. Custo dos 4 vol. em bruxura 2U560.

\section{Maio}

Os Administradores do fallido David Carfrae, pertendem vender com toda a brevidade toda a livraria que elle tinha na rua do Ouvidor N. 110, constituindo principalmente livros no idioma Inglez, e se vendem por preços muito commodor, no sobrado da casa N. 40, na rua da Alfandega, e tambem avisa se a todos os Snrs. Assignates que tiverem livros pertencentes a dita livrairia, que queirão Ter a bondade de os entregar na mesma casa ao Snr. Guilherme Binns.

Na rua Direita N. 130, vende-se por preço commodo o seguinte: Diccionario da lingua Portugueza do Moraes, Segunda edicção 2 vol.; dito da pronuncia Ingleza, Sheridan: Atala ou os amores de dous Selvagens no Dezerto; Collecção de instrucções para os Estudantes da lingua Latina, incluindo os costumes dos Romanos, e outras muitas cousas; o Misere exposto em pensamentos de afectos de humildade, tradusido do Italiano 640 réis; Historia das Revoluções de Portugal, de Verteau (em Francez) Vocabulario Portuguez, e Latino, 1 volume de Gilbraz, dito de escolhas de Anedoctas, dito de Vitorina (novella) o 2 tomo de Noticias de Portugal por Manoel Severim de Faria, que em grande parte he independente do primeiro, a Henriada disfarçada em versos burlescos, com notas criticas, $1^{\circ}$ e $3^{\circ}$, tomos de Leandro, ou o pequeno casal; todas as obras acimas são com uso.

Mr. Cogez estabelecido com loja de livros na rua do Ouvidor N. 156, annuncia ao Publico que tem de partir para a França com o projecto de traser pelos preços mais commodos huma nova collecção de livros classicos necessarios a instrucção, entretanto continua a vender a Encyclopedia em artigos separados. Tem tãobem a vender a ultima ediç̧ão em 6 vol. em $8^{\circ}$, do grande Diccionário de Medicina Buffon 127 vol. em $8^{\circ}$, todos encadernados ricamente e todos pelo breço o mais rascavel possivel. O mesmo se encarrega de traser todas as encomendas que se Ihe fizerem por escrito. 


\section{LIVROS A'VENDA}

Na rua Direita, n. 130, vende-se por preço commodo o seguinte: (...) a interessantíssima novella, Historia de Tom Jonnes ${ }^{198}, 4$ vols. traduzida do inglez, em portuguez, a melhor novella que se tem escrito naquelle idioma, e não poderá deixar de interessar a todas as pessoas amantes desta qualidade de leitura.

O director do armazem de livros Francezes, tem a honra de prevenir ao respeitável Publico, que a sua casa acaba de receber hum grande surtimento de livros encadernados, consistindo em obras de Medicina, Pharmacia, Cirurgia, Literatura, bellas letras, Artitheria, Fortificações, Jurisprudencia, Politica, \&c. e huma grande numero de romances de Pigault, Lebrun, Madame de Geulis, Walter Scott, Mesdames Cottin, Souza, Montaulieu, e escolha de viagens, por Maccarthey \&c., o director desta casa, querendo para mocidade em estado de se instruirem, vendera mui barato e tem mais de $800 \mathrm{vol}$, de differentes Auctores encadernados, que se vende por 640 cada hum; quem quizer dirija-se a tratar com Mr. Florence, em casa de Mr. Guinau, no canto da rua dos Ourives, e do Cano N. 70.

Leilão hoje 18 do corrente em casa de Lennox e Cannell N.11 rua detraz do Hospicio, de huma grande collecção de livros, a saber: Diccionarios no idioma Inglez e Latim, tratados sobre Chimica, Economia Polícia, Theologia, Historia Natural, e hum bom sortimento de Novellas no idioma Inglez, e algumas dos melhores classicos nos Idiomas Grego e Latim; principiará as 11 horas em ponto, e se vendem sem reserva por todo o preço.

${ }^{198}$ FIELDING, Henry. Tom Jones, 1749. 
Leilão que faz em Lennox \& Cannell N. 11 rua detraz do Hospício, de huma grande collecção de novellas Historicas, e algumas obras dos melhores Authores, bem encadernados, novos e usados, nos Idiomas principalmente Inglez, Francez, e Hespanhol: os quaes se hão de vener sem reserva por conta de quem pertencer. O leilão principiará as 4 horas em ponto da tarde.

\section{Junho}

04

LIVROS A'VENDA

A tradicção Escoceza - Saint Clair das Ilhas, ou os Desterrados na ilha da Barra $^{199}$ - vertida do Francez para o Idioma vulgar continua a vender se nas casas já annunciadas de Ferguson \& Comp., na rua da Quitanda armazem de Muzica entre a rua da Cadeia, e a do cano de João Pedro da Veiga \& Comp.; na mesma rua loja de livros ao canto da de S. Pedro; de Estevão Alvez de Magalhães, na rua dos Pescadores botica entre a travessa da Candellaria, e a rua Direita, de Santos José Rodrigues, armarinho na travessa da Alfanddega ao sahir para a rua Direita de Francisco Rodrigues, botica no largo da carioca; e de José Bernardo de Sá, loja de ferragens na Praça da Constituição. Preço $2 U 550$, os 4 vol. em brochura.

08

LIVROS A' VENDA

Na loja de livros de João Pedro da Veiga \& Comp. rua da Quitanda canto da de S. Pedro, há de venda aproximadamente chegados de França hum grande sortimento dos melhores Romances Francezes, como os de Sir Walter Scott, Madame Cottin, Reguault de Varin, Anne Radcliff, Madame Montolieu auctora de Carolina Lichfield e de S. Clair das Ilhas, Le Sage, Madame Souza, e muitos outros, que se podem vemder por preços muito commodos.

\section{Agosto}

01

COMPRAS

Quem tiver $02^{\circ}$ tomo da Roda da Fortuna, Vida de Alexandre e Jacinta, e o $3^{\circ}$ tomo dos Lances da Ventura, e o $1^{\circ}$ tomo das Aventuras de Crusoée ${ }^{200}$, e o $1^{\circ}$ tomo do Diabo Couxo, e queir vender ainda que tenha uso, annuncie pelo

\footnotetext{
${ }^{199}$ HELME, Elizabeth. St. Clair of the Isles or the Outlaws of the Barra. A Scottish Tradition, 1803.

${ }^{200}$ DEFOE, Daniel. The Life and Adventures of Robinson Crusoe, 1719.
} 
Diário para ser procurado.

Na rua do Cano N.103, ha para vender livros em Latim de differentes Auctores, Francezes, Portuguezes, Inglezes, e Hespanhoes, folhetos de differentes Novellas, dos quaes se vendem muito enconta, tambem existe a grande Historia do Conde Haque, em o idioma Francez, bem bomo tambem tem livros em branco para differentes escripturações.

LEILÕES

J. J. Dodsworth, faz leilão em sua casa N. 38 rua da Alfandega, no dia Sabbado 13 do corrente, de huma grande porção de trastes a saber: (...)huma grande colleção de livros, a saber: Humés History of England Johnsons Worhs, British Threater Gibbon's Public Characters, Count Grammont Aikens Manchester, Walter Scott's Novels, Southey's Thalaba, Gravuras Historicas em 3 tomos em follio dos Acontecimentos da Revolução Franceza (...) hoje Sexta feira 12 do corrente.

D. D. Dodsworth, faz leilão em sua casa N. 38 rua da Alfandega, no dia Sabbado 13 do corrente, de huma grande porção de trastes a saber: (...) huma grande colleção de livros, a saber: Humés History of England Johnsons Worhs, British Threater Gibbon's Public Characters, Count Grammont Aikens Manchester, Walter Scott's Novels, Southey's Thalaba, Gravuras Historicas em 3 tomos em follio dos Acontecimentos da Revolução Franceza (...) hoje Sexta feira 12 do corrente.

\section{Setembro}

Rua Direita sobrado $N^{\circ} 130$, vende-se com uso o seguinte: Historia de Portugal de la Clede $5^{\circ} 6^{\circ}$ vol 1280: dita por Moraes $3^{\circ}$ vol. 640; dita do celebre Sevagy 480., o Solitario de Ferrasson 480; Compendio Historico de Fleury $4801^{\circ} \mathrm{vol}$; Portugal Illustrado pelo sexo Feminino: Noticias Historicas 
de muitas heroinas Portuguezas que florecerão em Virtude, Letras, e Armas $1^{\circ} \mathrm{vol}$ 640; Filosofia de Principes $1^{\circ}$ e $3^{\circ}$ vol. 960: Tardes Divertidas e Conversações Curiosas sobre a Historia Natural Sacra, Civil, e Fabulosa, $2^{\circ}$, e $3^{\circ}$ vol. 1280 , Viagens de Gulliver ${ }^{201} 1^{\circ} \mathrm{vol}$, contem a primeira, e Segunda parte, 640: Robinson Crusóe $2023^{\circ}$ vol. 640: Cathecismo grande de Montiplier $3^{\circ}$ vol. 640; obras escolhidas do Marquez de Caraciolli $6^{\circ}$, e $8^{\circ}$ vol. 960: Historia Critica ao Theatro 640.

\section{Outubro}

Na rua Direita sobrado N. 130, vende-se com uso o seguinte: os Syharitas, ou os subterraneos de Piombino, (novella) 2 vol. 1280; Panegyricos do grande João de Barros, 640, Tempos de Agora, 640, Historia Crítica do Theatro, na qual se tratao as cauzas da decadencia do seu verdadeiro gosto, traduzida em Portuguez, 640, Calculo Defferencial, e Integral de Bezout, 480, Pamella Andrews $^{203}$, segundo vol. 640, Aventuras de Estevão Gonçalves, $2^{\circ}$ e $3^{\circ}$ vol. 1280, Isidoro e Horaida $1^{\circ}$, e $2^{\circ} \mathrm{vol}$. 1280, D. Quixote de la Manche, $2^{\circ}, 3^{\circ}, 4^{\circ}$, $5^{\circ}$, e $6^{\circ} \mathrm{vol}$. 3200, Vaigens de antenor pela Grecia e Asia, $3^{\circ} \mathrm{vol}$. 320: Ilha Incognita, $6^{\circ} \mathrm{vol}$. 640 .

\section{Novembro}

\section{LIVROS A'VENDA}

Na rua Direita sobrado N. 130, vende se com uso o seguinte; 3 vol. da llha Incognita, com 6 estampas, 960, 4 ditos da Revolução da França, 1U440, 1 dito da Vida, e aventuras admiraveis de Robensons Crusoe ${ }^{204}, 320,1$ dito das Aventuras de Telemaco 320, 2 ditos de Filosophia de Pricipes 640, 1 dito da Nova e Completa collecção de Viagens, e fornadas as quatro partes do mundo 320, 1 dito das Viagens de Gulliver ${ }^{205}$, contem duas Viagens completas, huma a terra dos anões, e outra a dos Gigantes 480, 2 ditos de

\footnotetext{
${ }^{201}$ SWIFT, Jonathan. Gulliver's travels, 1726.

${ }^{202}$ DEFOE, Daniel. The Life and Adventures of Robinson Crusoe, 1719.

${ }^{203}$ RICHARDSON, Samuel. Pamela. 1742.

${ }^{204}$ DEFOE, Daniel. The Life and Adventures of Robinson Crusoe, 1719.

${ }^{205}$ SWIFT, Jonathan. Gulliver's travels, 1726.
} 
Isidoro, e Oraida, ou os Presioneiros da Montanha 720, 2 ditos das Aventuras de Estevão Gonçalves, ou o Rapaz do bom humor 720, 1 dito de Pamella ${ }^{206}$ 4805 ditos da Vida de D. Quixote dela Mancha 2U560, 2 ditos do Genio do Christianismo, 1 dito da Vida de Lord Wilingtons 320: tudo isto he em Portuguez.

\section{Dezembro}

16 LIVROS A' VENDA

Na rua Direita perto da das Viollas, sobrado N. 130, vende-se com uso o seguinte: (...) a mais heroica virtude, ou a Virtuoza Pamella ${ }^{207}$ Comedia 180, tudo isto he em Portuguez.

\section{6}

\section{Janeiro}

12

COMPRAS

Quem quizer vender por preço commodo livros usados, sendo em Portuguez, a saber: Historias, Novellas, Poesias de Authores celebres, ainda que Ihes faltem alguns volumes; (...), sobrado N. 130.

13

LIVROS A' VENDA

Na loja de livros de Cremiere, rua dos Ourives N. 178, ha para vender (...), obras de Schakspar em Inglez 23 vol. em $8^{\circ}$ por 24U000rs., Novellas Inglezas por 640 o vol.; (...), tambem alugão se por mez, ou dias por preço commodo (...)

\section{Abril}

10

LIVROS A'VENDA

Na rua Direita N. 130, vende se sem uso o Seguinte em Portuguez: Atala, ou os Amores de dous selvagens no dezerto, 640, (...); saint Clair das Ilhas, ou os

\footnotetext{
${ }^{206}$ RICHARDSON, Samuel. Pamela. 1742.

${ }^{207}$ Idem.
} 
desterrados na Ilha da Barra ${ }^{208}, 4$ vol. 2240; (...)

Maio

06

LIVROS A' VENDA

Na rua Direita armazem N. 136, ha para vener huma linda collecção das obras Inglezas do celebre Auctor Walter Scott, quem quizer comprar dirija-se no mesmo armazem das 9 horas da manhã até ao meio dia.

\section{Agosto}

Precisa-se comprar as obras seguintes em segunda mão, Viagens de Guliver ${ }^{209}$, Lances da Ventura ou Acasos da Desgraça, Carolina De[ ]het fiel, o Jovem Ceciliano, os Amores de dous selvagens no deserto, Paulo e Virginia, quem as tiver e queira vender, procure na rua da [ ] aopé da rua das Viollas N. 217.

\section{Setembro}

18

\section{LIVROS A' VENDA}

Na rua Direita N. 61, vende-se por preço commodo as obras seguintes: Recreação Filozofica do Padre Theodoro de Almeida 10 vol., Feliz Independente do mesmo 3 vol., Poezias do Abbade de Fazem 2 vol., Amizades perigozas 3 vol., Almocreve de Petas 3 vol. Camera Optica, Jogo dos Dotes, Barco da Carreira dos Tollos, Elementos de Civididades, Pamela, ou a virtude exaltada. ${ }^{210}$

\section{Outubro}

04

ACHADOS

Quem perdesse o $4^{\circ}$ volume das obras de Walter Scott, e o $2^{\circ}$ de Mortanval, ambos com encadernação de marromquin verde; procure em casa do Deputado Lino Coutinho, que forão achados por hum seu criado na noite de 26 , no principio da rua Direita antes de chegar a botica do Snr. João de Pinho.

\footnotetext{
${ }^{208}$ HELME, Elizabeth. St. Clair of the Isles or the Outlaws of the Barra. A Scottish Tradition, 1803.

${ }^{209}$ SWIFT, Jonathan. Gulliver's travels, 1726.

${ }^{210}$ RICHARDSON, Samuel. Pamela. 1742.
} 


\section{7}

\section{Fevereiro}

Na rua do Lavradio N. 27, vende-se com algum uso os seguintes livros em Portuguez: (...) Leandro, ou o pequeno Cazal 4 vol., a vida de Marianna, ou as aventuras da Condessa T.... 4 vol., os dous Infelizes 4 vol., Cecilia de Chatenai 2 vol., as desgraças da Inconstância 2 vol., diverços vol. do Viajante Universal; Clara Harlowe ${ }^{211}$ diverços vol., Gusma d'Alfarache $2^{\circ}$ vol. Deão de Killerine $4^{\circ} \mathrm{e}$ $5^{\circ}$ vol., (...) Anna Greuwil $2^{\circ}$ vol., Estevão Gonçalves $3^{\circ}$ vol., Joaninha, ou a Engeitada Generoza $1^{\circ}$ vol; Viagens d'Altina $3^{\circ}$ vol, (...) Izidoro e Horaida $1^{\circ}$ e $2^{\circ}$ vol., novidades Literarias $1^{\circ} \mathrm{vol}$. N. B. os livros acima vende-se juntos ou separados.

\section{Abril}

Quem tiver a Novella intitulada, Amanda e Oscar, $^{212}$ e a queira vender, póde procurar no Campo da Acclamação casa N. 15.

\section{Maio}

Na rua Direita sobra N. 130, vende-se com uso os seguintes volumes, todos em Portuguez: (...) 1 das Desgraça da Inconstâncias; 640: 1 das Viagens de Antenor; 400: (...) 2 das Viagens de Goliver, a paízes remotos ${ }^{213} 1 U: 1$ de Gil Bras (...)

\footnotetext{
${ }^{211}$ RICHARDSON, Samuel. Clarissa, or, the History of a Young Lady. 1748.

${ }^{212}$ ROCHE, Maria Regina. The Children of Abbey, 1796.

${ }^{213}$ SWIFT, Jonathan. Gulliver's trave/s, 1726.
} 


\section{LIVROS A'VENDA}

Na rua Direita sobrado N. 130, vende-se com uzo as seguintes obras todas em Inglez: (...) The seasons, by Jamos, Thomson 800: A Winter Seasons, With-plates 480; (...); The Indian Cottage 320: The Young, Student's Pocket Conpaion 640 (...).

Na rua da Villas N. 162, vende-se os livros seguintes (...); Obras de H. Fielding, ou escolha dos Melhores Romances Inglezes; os Seculos Christãos (...).

\section{Setembro}

Na loja de livros de João Baptista Bompard, rua dos Pescadores N. 49, se acha a mui ingraçada novella Evaristo e Theodora, ou o Castello de Closteru, $8^{\circ}$ por $4 U$ réis; Alberto, ou o Deserto de Strathuaveru de Mistriss Helme, $8^{\circ} 3$ vol. por 4Uréis. Na mesma loja se acha muitas outras obras, tanto em Portuguez, como em Francez, vindos pelo navio Camões.

\section{OUTUBRO}

15

LIVROS A'VENDA

Na rua dos Ourives N. 86, acaba-se de receber hum novo sortimento de Novellas Portuguezas, e Francezas, para se alugar por dias, ou por mez. Os livros principaes Portuguezes são as mil e huma noites, mil e hum quarto de hora, Tom Jones $^{214}$, filosofo Inglez, escolha das melhores novellas e contos, D. Quixotte, diabo côxo, Vicctor ou a menina da Selva, Historia Galante do Jovehem Sicilien, Gabinete histórico, e muitos outros. Os livros Francezes principaes são: Oeuvres completes de Pigault-lebrun, de Jouy, de Md. De Montolieu, de Md. De Genlis, de Marmontel, de Moliére, maior parte de Walter-Scott, le Voyageur Français de Laporte, Répertoire general de Theatres, e muitos outros. Na mesma loja se acha hum sortimento formidavel de musica de Rossine, e dos melhores Autores, para

\footnotetext{
${ }^{214}$ HELME, Elizabeth. St. Clair of the Isles or the Outlaws of the Barra. A Scottish Tradition, 1803.
} 
todos os Instrumentos; ha tãobem cordas de Napoles, e papel de musica pautado.

Preciza se comprar a obra de Saint Clair em Portuguez, estando em bom uso; quem a tiver e quizer vender por commodo preço, póde declarar por este Diário a sua moradia para ser procurado.

26

LIVROS A'VENDA

Na loja de Livros de João Baptista Bompard, rua dos Pescadores N. 49, se acha Merope tragedia de M. de Voltaire, vertida em Portuguez, $8^{\circ}$ por 640; (...) Historia de Saint Clair das Ilhas $8^{\circ} 3$ vol. por 6:000 rs (...).

\section{Novembro}

LIVROS A'VENDA

Na rua de S. Pedro N. 166, tem para vender os livros seguintes: Oevres de Choisier de Quinault 2 vol. 320 réis (...) Robison Crosué215 4 vol. 2:500; (...)

Aventures de Gil Braz de Santilhane em Hespanhol 4 vol. 2:560 (...), e outros [?] que se póde ver a lista.

\section{Dezembro}

06

LIVROS A'VENDA

Na loja de papel de Campos Bellos, rua do Ouvidor N. 75, achão-se à venda os livros seguintes, chegados proximamente de Lisboa: (...) Historia de Gil Braz de Santilhana, dita Galante do Jovem Ciciliano, Almocreve das Petas, o Espreitador do Mundo Novo, Hospital do Mundo, Barco da Carreira do Tolos, Recreações do Homem Sensível, A Ilha Incognita, Lances da Ventura, Viagens D'Altina, Vida e Aventura de Robinson Crusoé, Carolina de Lichtfield, Novellas Galantes, As ruinas de volney, D. Branca, ou a Conquista de Algarve; Aventuras do Marquez de Renoncour, o Desgraçado Napoilitano, ou vida de Roselli; os Amantes Desgraçados,

${ }^{215}$ DEFOE, Daniel. The Life and Adventures of Robinson Crusoe, 1719. 


\section{$(\ldots)$.}

Na rua do Ouvidor N. 188, vende se as obras seguintes em Portuguez: (...) Paulo e Virginia, $1 \cup 000$ (...) na mesma casa se continua a vender livros.

Na rua do Ouvidor N. 138, acha-se á venda em Portuguez, Irmã, ou as desgraças de huma jovem orfa 4 vol. 4:000; Pamella ${ }^{216} 2$ vol. 2:400; (...)

\section{8}

\section{Janeiro}

09

LEILÕES

Carlos Cannell faz leilão hoje Quarta feira 9 do corrente, no seu armazem na rua detraz do Hospicio N. 3, defronte da rua da Candellaria, de hum ellegante sortimento de moveis (...) e huma porção de livros em Francez e Inglez; obras de Rosseau, Voltaire, Oeuvres Choisies de Cobardeau, Regnard, Viollas, (...).

Douville e Laboissiére, fazem leilão hoje 18 do corrente, em sua casa rua da Quitanda N. 99 as 10 horas e meia da manhã, de hum grande sortimento de livros em Francez, Inglez, Hespanhol, e Portuguez \&c, sendo as obras dos melhores autores de Medicina, Cirurgia, Jurisprudencia, e outras. Amanhã venderão huma

\footnotetext{
${ }^{216}$ RICHARDSON, Samuel. Pamela. 1742.
} 
factura de huma loja de quinquilhereias e fazendas, ou em lotes (...).

\section{Março}

Douville \& Comp, fazem leilão hoje 15 do corrente, as 6 horas e meia da tarde, em sua casa rua da Quitanda N. 99, de huma porção de enstrumentos (...) e huma porção de livros curiosos Francezes, Inglezes, e Portuguezes.

Douville \& Comp, fazem leilão hoje 17 de corrente, em sua casa rua da Quitanda N. 99, de huma porção de ferragens, e quinquilherias de todas as qualidades, livros Inglezes, Portuguezes, e Francezes (...).

J. J. Dodsworth, faz leilão em sua casa N. 38 rua da Alfandega hoje Segunda feira 17 do corrente de huma grande porção de livros a saber: a celebre obra de Pouthier sobre a Legislatura em 11 vol., Oeuvres de le Sage 12 vol., Histoire des Ducs de Bourgogne 13 vol., Oeuvres de Buffon 12 vol. com estampas, Oeuvres de Lord Byron 8 vol. com estampas ricas, Oeuvres de Racine 5 vol., Dictionaire Historique 13 vol., Marmontel 18 vol., Esprit de l'Encyclopédie 15 vol., Emmerick 8 vol., Histoire d'Angleterre 18 vol., Declaure Histoire de Paris 10 vol., Oeuvres de Fenelon 19 vol., Memoires de S. Helene 8 vol., Oeuvres de J. J. Rosseau 20 vol., Repertone du Theatre Français 51 vol., obras de Walter Scott 100 vol., Oeuvres de Pigault de Brum 77 vol., Voltaire complet 56 vol., (...) \&c \&c que se vendem impreterivelmente por todo o preço. Principia ás 10 horas.

Na loja de livros de Albino Jordão rua do Ouvidor N. 138, acha-se á venda as seguintes Novellas todas em Portuguez e encadernadas, Historia de Gil Braz de Santilhana mui bom papel 4 vol. 6:000 Pamella Andrens ou a virtude recompensada ${ }^{217} 2$ vol. 2:560; Paulo e Virginia 1:280; Cartas de huma Piruviana; nesta Novella se pertende descrever os costumes dos Européos 2 vol. 1:6000; a Filosofa por amor, ou cartas de dois amantes apaixonados virtuosos; esta Novella he huma das mais interessantes que se tem traduzido em Portuguez 2 vol. em [?]

\footnotetext{
${ }^{217}$ RICHARDSON, Samuel. Pamela. 1742.
} 
1:600; Vida aos amores Heloise a Beilard, com as cartas amorozas da correspondencia destes infelizes amantes 2 vol. 1:920; Mil e Hum Quarto de Hora 3 vol. 4:000; As ultimas despedidas da Marechal de *** 1:280; As desgraças de huma Joven Orfan 4 vol. 3:200; Bliombe o Novella de Mr. Florian 640; na mesma casa ha outras muitas obras que se darão por preço rasoavel.

Perdeo-se no dia 16 do corrente, da mão de hum rapaz o $6^{\circ}$ tomo em broxura da Historia d'Amanda e Oscar; ou a familia de Duneiathe ${ }^{218}$ : quem a achou, e queira restituir, leve ao largo de S. Francisco de Paula, lado da Igreja o primeiro sobrado N. 3, que se gratificará com generosidade o seu trabalho.

Roga se a quem tiver achado o terceiro volume de huma obra Ingleza - Sir Michael Scott que foi perdido no Cattete, no dia 16 do corrente, entre as ruas da Pedreira, e a da Princeza, e queira mandar a rua da Alfandega N. 17, ou a rua Direita N. 151, que receberá de alviçarasa $4 \$ 000$ réis.

\section{Abril}

Na rua de S. Pedro N. 166, ha para vender os livros seguintes:' (...) Lectures de une Mere a sa Fille 640; Oeuvres de J. de Racine 5 vol. de $4^{\circ}$ encadernadas a 1:600, (...); Marie la Fille de l'Auvengle Romance de 1827, 1 vol. 800; (...); Voyages de Guliver $^{219}$ com estampas encadernadas 2 vol. 800; Fablier de l'Enfance e da Jueneuse 1 vol. 640; Fables de Perrault 1 vol. 800; (...); e outras muitas obras de diverços Authores de que se póde ver a lista.

\section{Maio}

Na rua do Sabão N. 102, ha para vender os seguintes livros: (...) Cartas de Carlos e Maria, com pouco uso; 640; (...) Thesouro de meninas com estampas, já uzado 400 (...).

\footnotetext{
${ }^{218}$ ROCHE, Maria Regina. The Children of Abbey, 1796.

${ }^{219}$ SWIFT, Jonathan. Gulliver's travels, 1726.
} 
Na rua de S. Pedro loja N. 166, tem para vender os livros seguintes (...) Saint Clair das Ilhas ${ }^{220} 4$ vol. 1:920; La Contesse de Fargi par Madame de Souza 4 vol. 2:560; Hallidon Hill por Walter Scott 1 vol. 640 (...); Louvet de Courvray dite $1: 600$.

Na loja de livros de José Albino, rua do Ouvidor N. 138, acha se á venda o seguinte em Portuguez: Merope, Tragedia de Mr. Voltaire impressa em Londres 320; Vida de Bonaparte 480; Extractos da Cartas de Maria Wollstoncraft relativas a suecia noruega, e dinamarca, e huma breve noticia de sua vida, offerecida ao bello sexo 640; Vida de Heloisa e Abeilard, com as cartas amorozas da correspondencia destes infelizes amantes 2 vol. 1:280.

\section{Junho}

07

LEILÕES

J. J. Dodsworth, faz leilão do primeiro andar de sua casa N. 40, rua da Alfandega, no dia Sabbado 7 do corrente, dos moveis ricos que pertencião ao fallecido Guilherme Boog Esq: entre os quaes se achão hum mui grande e elegante guarda livros (...), e livros pelos seguintes auctores Sir Walter Scott, Hume e Smolletti, History of England, Westons Josephus, Johnsons Dictionary em quarto, Bayleys Touver of Landon, 2 vol. em quarto com soberbas estampas, Spectator 8 vol., em 4, em oitavo; Lord Byron works, Letterary Gazette (...). Principia as 10 horas e meia.

Ha para vender na rua dos Ourives N. 86, The work of Lord Byron, complete in one vol. The poetical works of Walter Scott complete in one vol. The poetical works of John Milton complete in one vol. The spectator $10 \mathrm{vol}$. in $8^{\circ}$ Travels in Brazil by Henry Koster 1 vol. in fol. with col. (...) e na mesma casa se achão para vender muitos mais livros Inglezes e Francezes.

\section{Agosto}

01

LIVROS A'VENDA

Na rua dos Ourives N. 86 se alugão livros Francezes e Portuguezes, entre estes

\footnotetext{
${ }^{220} \mathrm{HELME}$, Elizabeth. St. Clair of the Isles or the Outlaws of the Barra. A Scottish Tradition,
} 1803. 
se achão as melhores Novellas Portuguesas como Gilbras de Santilhana, Novellas Orientaes, Mil e huma Noite, Viagens de gulliver, Robinson Crusoé221, Celestina, Noites Clementinas, ditas Romanas, D. Quixote de la Mancha, Deão de Kellerine, Tom Jones ${ }^{222}$, Victor ou o Menino da Selva, o Filosofo Inglez, Piolho Viajante, Gabinete Histórico, Carolina de Lichtfield, e outras muitas mais e entre aquelas se achã as obras com letas de Pigault Lebrun, S. Jouy, Walter Scott, Prévost, Madame de Genlis, Madame de Montolieu, Montesquieu, le voyagens Français de la Porte, Rápertoire du Tréatre Français et autres Romains choisis, dos quaes tem Catalogos Impressos ha tambem para vender Santa Clair das Ilhas $^{223} 4$ vol. ,vida de João de Castro, 1 vol, Vida e amores de Heloise e Abeilard, 2 vol. (...) o Consorcio das Flores, A arte de conhecer os homens 1 vol., o Velho paisano polonez, $1 \mathrm{vol}$. (...). O dono da casa roga a todas aquellas pessoas que Ihe tem feito a honra de serem seus assignantes, cujos, tem alguns livros em seu poder a muito tempo, o favor de os entregar para evitar o encommodo de [?] a casa dos ditos Snrs. Procuralos.

\section{Setembro}

02

\section{LEILÕES}

J. J, Dodsworth faz leilão no primeiro andar da casa da rua da Alfandega N. 40, hoje Terça feira 2 do corrente, de huma grande porção de trates pertencentes a huma pessoa que se retira dessa Corte,a saber: (...) e 1500 livros em differentes idiomas, Francezes, Inglezes, e Portuguezes, entre os quaes se achão Boyers Diction nary French and English, obras de Sir Walter Scott, Walpoles Letters, e Memoirs of Babers, Movres Life of Sheridan, Thacherays Life of Pitt, obras de Voltaire Boileau, Rosseau \&c., hum Mappa Militar de Portugal e Hespanha, de 2 grandes folhas Imperiaes: principiará ás 10 horas e meia.

06 LIVROS A'VENDA

Livros novos em Hespanhol, á venda por preços modicos na livraria de Souza, Láemmert, e Comp., rua dos Latoeiros N. 88: Julia ó la nueva Heloise; Cartas de dos Amantes por J. J. Rosseau, 4 vol.; Los Martyres ó el Triunfo de la Religion

\footnotetext{
${ }^{221}$ DEFOE, Daniel. The Life and Adventures of Robinson Crusoe, 1719.

${ }^{222}$ FIELDING, Henry. Tom Jones, 1749.

${ }^{223}$ HELME, Elizabeth. St. Clair of the Isles or the Outlaws of the Barra. A Scottish Tradition, 1803.
} 
Christiana, por Chateaubriand, 2 vol.; Vida de Napoleon Buonaparte E [?] Francezes, precedida un [?] de la revolucion francesa, por Walter Scott, 18 vol; Memorias de Napoleon escriptas por el mesmo en Santa Helena, y publicadas por los generales (...).

Ha para vender na rua dos Ourives N. 86, as Novellas Seguintes em Portuguez: Historia de Gil Braz de Santilhana 4 vol. com 14 fig., 1:880; Caverna da Morte. 1 vol., 1:300; Belizario 1 vol. 1:600; Paulo e Virginia, 1 vol., 1:600; Atala, 1 vol., 1:600; Economia da Vida, 1 vol. 1:600; Novellas escolhidas, 2 vol 3:200; Imitação de Christo 1 vol., 6 fig. 2:560; Ordem da Missa, 1 vol. 1:600; todas aquella obras são de huma rica encadernação: Carolina de Litchfield 2 vol. 2:560; Vida ou os Amores de Heloise e Abeilard, 2 ol. 1:600; Saint-Clair das Ilhas ${ }^{224}, 4$ vol. 3:840; as Frutas do Brazil, 1 vol. 1:000; o Consorcio das Flores, 240 (...).

\section{9}

\section{Janeiro}

Ha para vender na livraria de Crémiére, na rua dos Ourives $N$. 86, os livros seguintes em Portuguez: obras completas de Filiato Elysio, $11 \mathrm{vol}$ em $4^{\circ}$ 16\$000rs.; Historia de Gilbraz, 4 vol. com 14 figuras 10\$000; Belizario 1\$600; Camões poema, 1\$920, (...) Novellas escolhidas, 2 vol. 3\$200; (...) Collecção de pedaços em prosa, e em verso, extrahidos dos melhores Authores Franceses, e Portuguezes, 2\$240; (...); todas estas obras são impressas em Paris, e a encadernação dellas he Franceza; Saint Clair das Ilhas, 4 vol. 3\$200, as Frutas

${ }^{224}$ HELME, Elizabeth. St. Clair of the Isles or the Outlaws of the Barra. A Scottish Tradition, 1803. 
do Brasil, 800; o Paisano polonez, 240; Arte de conhecer os homens; 120; 0 Consorcio das Flores de Bocage, 240 (...). Na mesma casa há um bem escolhido sortimento de mais de $3 \$ 000$ vol. de livros Portuguezes e Francezes, para alugar por mez, ou por dias.

\section{Março}

04

\section{LEILÕES}

Hoje Quarta feira 4 do corrente, Goupil faz leilão em sua casa rua do Ouvidor N. 64, de alguns lotes de livros Inglezes, Francezes, e trastes, espelhos, luvas, thesouras, canivetes, duas serpentinas, alguns quadors, alguns pretos novos, dous moleques, bejoterias, huma caixa de chapéos, e muitas outras fasendas. Principiará ás 10 horas e meia.

Hoje Terça feira 17 do corrente, Goupil faz leilão em sua casa na rua do Ouvidor N. 64, de alguns bons moleques novos (...); igualmente se vendem alguns lotes de livros, Franceses, Ingleses e Portuguezes, (...) principiará as 10 horas e meia.

30

\section{LEILÕES}

J. J. Dodsworth faz leilão em sua casa N. 38 rua da Alfandega, hoje Segunda feira 30 do corrente, as 10 horas e meia da manhã, de huma grande porção de livro entre os quaes se achão, Kelly, Camblat, Napoleon Buonaparte, Leife Memoires of Mr. Siddons, obras de Sir Walter Scott differentes numeros de New Monthly Magazine, Quartely Review Edenburbg Review Blackwoods Magazine (...).

Quem tiver, e queira vender em bom estado as obras seguintes: Saint Clair das Ilhas da Barra ${ }^{225}$; Contos de [M?góa\}; Carlos e Tania; e o terceiro tomo da obra de Gil Braz de Santilhana, póde annunciar por este Diario, ou dirigir-se a praia de S. Francisco da Prainha N. 5, na Tanoaria de Joaquim Ferreira da Costa.

${ }^{225}$ HELME, Elizabeth. St. Clair of the Isles or the Outlaws of the Barra. A Scottish Tradition, 1803. 
Carlos Cannell faz leilão hoje Terça feira 14 do corrente, em suia casa na rua detraz do Hospício N. 33 de diverças ferragens (...) livros em Inglez e Francez, (...), tudo será vendido infallivelmente as 10 horas e meia.

15

LIVROS A'VENDA

Na loja de livros de Albino Jordão, na rua do Ouvidor N. 138, acha-se á venda o seguinte em Portuguez: Protecção á Franceza por José Daniel, 160 rs.; dita dos Inglezes, 100 rs; (...) Merope, Tragedia de Mr. Voltaire, 320 rs; Successos do Aletenjo, 100 rs.; (...) Extrato das Cartas de Maria Wolltsnecraft 320 rs.; (...) Filosofa por Amor, ou Cartas de dois Amantes apaixonados e virtuosos, 2 vol., 1280 rs.; Cartas de huma Peruviana, ou Historia de huma Princeza do Perú, 2 vol, 960 rs.

\section{Setembro}

03

PERDAS

Quem achasse o primeiro tomo da obra intitulada o Saint Clair das Ilhas ${ }^{226}$ (em Portuguez) póde dirigir-se á Imperial Lapidação dos Diamantes, e fallar com o Sr. Cezar, e juntamente mostras-se-Ihe os mais volumes irmãos do dito, isto das 8 horas ás 3 da tarde, do que receberá alviçaras pelo que exigir.

Na casa de Souza Laémmert e Comp., rua dos Latoeiros N. 88, vende se o Parnaso Lusitano, ou (...).

Quem quiser comprar as obras completas de Voltaire em $70 \mathrm{vol}$ em $4^{\circ},(\ldots)$, as do Doutor Alan[...] em 18 vol. bem encadernados por 36\$000rs.; as de Depradt, em 37 vol., por $66 \$ 000$ rs.; as de Walter Scott em 57 vol., por $50 \$ 000$ rs.; e mais algumas outras: procure na rua da Alfandega N. 73

${ }^{226}$ HELME, Elizabeth. St. Clair of the Isles or the Outlaws of the Barra. A Scottish Tradition, 1803. 
Na rua do Ouvidor loja N. 138, comprão-se as Novellas seguintes em Portuguez: Feliz Independente, Gil Braz, Joven Ciciliano, Saint Claire das IIhas, Camponeza Exaltada, Joaninha, Mathilde ou o Sobterraneo, e outras quaesquer Novellas.

\section{Outubro}

05

LIVROS A'VENDA

Na loja de livros de Albino Jordão, rua do Ouvidor N. 138, acha-se á venda o seguinte em Portuguez: Protecção á Franceza, por José Daniel, 160; dita dos Inglezes, 100 rs.; Improvisos de Bocage dedicados aos seus bons amigos, 160; Epi[ ] na morte do dito 160; Consorcio das Flores pelo mesmo, 240; Jardins Poema pelo dito, 480; Eufemia, ou o Triumpho da Religião pelo dito, 480; Ulissèa Libertada, 100; Merope Tragedia de Mr. de Voltaire, 320; Successos do Alentejo 100; collecção de Poesias Cansonetas, ternas e amorosas, por hum apaixonado do bello sexo, 240; (...); extractos das Cartas de Maria Wolstonecraft, 320; Historia da Grecia, 2 vol. $4 \$ 000$ rs (...); cartas de huma Princeza do Perú, 2 vol. 960 (...).

06

LIVROS A'VENDA

Na rua da Valla N. $1162^{\circ}$ andar, ha para vender as obras seguintes: Buffon, 127 vol. com gravuras; Walter Scott, 108 vol. com gravuras, Condillac, 23 vol.; [...]; J. J. Rosseau, 25 vol. (...); todos estes livros vendem-se juntos ou separados.

\section{Novembro}

30

COMPRAS Na rua do Ouvidor N. 138, continua-se a comprar Novellas, como Gil Braz, Tom Jones $^{227}$, Saint Claire das Ilhas ${ }^{228}$ \& Historias como a do Brasil, a Romana, e quaesquer dos Livros que se dão nas Academias, ou Aulas Públicas desta Corte, sendo tudo em bom uso, e por preço commodo.

\section{Dezembro}

${ }^{227}$ FIELDING, Henry. Tom Jones, 1749.

${ }^{228}$ HELME, Elizabeth. St. Clair of the Isles or the Outlaws of the Barra. A Scottish Tradition, 1803. 
J. J. Dodsworth, faz leilão hoje 10 do corrente, no primeiro andar de sua casa $N$. 40 rua da Alfandega ás 11 da manhã, de hum grande sortimento de mover (...) e huma porção de livros nos Idiomas Francez, Inglez, Hespanhol, Portuguezes, Latim, Alemão, e Hollandez (...).

Na loja de livros de Albino Jordão, na rua do Ouvidor, N. 138, vendem-se as seguintes Novellas encadernadas: Lances da Ventura, 6 vol. $9 \$ 000$ rs.: Recreações do homem sensivel, 3 vol. $7 \$ 000$ rs; o Jovem Cisiliano, 4 vol. $5 \$ 500$ rs.; Tom Jones, ou o Engeitado ${ }^{229} 4$ vol. $6 \$ 000$ rs.; Robson Crosoè ${ }^{230} 4$ vol. 5\$000; Carlos e Fany, 3 vol. $4 \$ 800$ rs.; Mil e hum Quarto de Hora, 3 vol. $4 \$ 800$ rs; Orlando Amoroso, 3 vol. 4\$800rs.; Chronica do Imperador Clarimundo, 3 vol. 4\$000rs; os Subterraneos de Pianbino, 3\$000; Cartas de dous amantes apaixonados e virtuosos, 2 vol. em 4, $1 \$ 800$ réis; Desgraçado Napolitano $1 \$ 800$ rs; Carlos Magno, 2\$000rs.; Cartas de huma Peruviana, 2 vol. com brochura 960; Feliz Independente, 3 vol. com 24 estampas $8 \$ 000$ rs.

\section{0}

\section{Janeiro}

Achão-se á venda, na rua da Cadeia armarinho N. 7, as Novellas seguintes em muito bom uso - O Bacharel de Salamanca - Rimas de Mattos - Os Martyres Jogo dos Dotes - Evaristo, e Theodora - Lances da Ventura - Viagens de Guliver - Obras completas de Camões - Maria, ou a Menina desgraçada - Votos temerários, ou o enthusiasmo - Zadig, ou o destino - Meditações de Hervey Vida e Aventuras de Robinson Crusoé - Madovia e Frederico, ou as Minas de

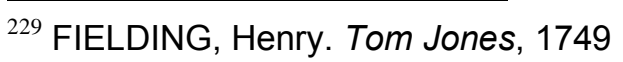

${ }^{230}$ DEFOE, Daniel. The Life and Adventures of Robinson Crusoe, 1719.
} 
Tyrol.

Crémiére, Livreiro na rua dos Ourives N. 86, tem a honra de offerecer ao respeitável Publico, hum lindo sortimento de livros em Portuguez, e em Francez, para alugar-se por mez ou por dias, entre estes se acha Etelvina, Gilbraz, Leandro, Caraline de Gilchtfield, Mil e huma noute, Victor, Cubinete histórico, Filosopho inglez, Deam de Killerine, Lances da Ventura, Piolho Viajante, Tom Jones $^{231}$, Mil e hum quarto de hora, Escolha das melhores Novellas, Saint-Clair das Ilhas ${ }^{232}$, Irmãa, Amanda e Oscar ${ }^{233}$, Novellas Orientaes, Ilha Incógnita, Filinto Elysio, e mais de 200 outros que se poderá ver sobre o Cathalogo impresso; o gabinete Francez tem mais de 2500 vol. dos melhores aucthores.

02 LIVROS A'VENDA

Na rua dos Ourives $n$. 86, vendem-se os livros seguintes em Portuguez: $D$. Quixote, 6 vol. $6 \$ 000$ rs.; Viagens de Guliver ${ }^{234}$, 3 vol. $4 \$ 000$ rs.; Atala, $1 \$ 600$, Caverna da Morte, $2 \$ 000$ réis; Belisario, $2 \$ 000$ rs.; Vida de D. João de Castro, $2 \$ 880$ rs.; Clara d'Alba, $2 \$ 000$ rs.; Isabel, $2 \$ 000$ rs.; Dote de Suzaninha, 2 vol. 4\$000; Os Sybaritos, 2 vol $1 \$ 280$ (...) as Desgraçadas da Inconstância, 2 vol. 2\$000rs.; Carlos e Maria, $1 \$ 200$ (...).

Na rua do Ouvidor, loja n. 75, ha para vender os livros seguintes: Historia Galante do Joven Siciliano, 4 vol., a Ilha Incógnita, 6 vol.; Vida e Aventuras Admiráveis de Robinson Crusoé 235 , 2 vol.; Historia de Gil-Braz de Santilhana, 4 vol.; 0 Guarda Livros Moderno, 3 vol.; Novellas Galantes e Instructivas, 2 vol.; Recreações do Homem Sensível 5 vol.; Carolina de Lichtfield, ou o Triunfo da Virtude, 2 vol; Viagens D’Altina, 4 vol.; Lances da Virtude, Acasos da Desgraça, e

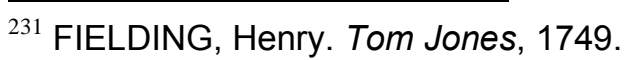

${ }^{232}$ HELME, Elizabeth. St. Clair of the Isles or the Outlaws of the Barra. A Scottish Tradition, 1803.

${ }^{233}$ ROCHE, Maria Regina. The Children of Abbey, 1796.

${ }^{234}$ SWIFT, Jonathan. Gulliver's travels, 1726.

${ }^{235}$ DEFOE, Daniel. The Life and Adventures of Robinson Crusoe, 1719.
} 
Heroísmo da Virtude 6 vol.; O Desgraçado Napolitano, ou Vida de Monsieur Roselli, 1 vol; Direito Mercantil, 2 vol.; Volney, ou Ruínas de Palmira, com o Cathecismo da Lei Natural, 1 vol; Os Amantes Desterrados na Sibéria, 1 vol.; Saint Clair das Ilhas, ou os Desterrados da Barra ${ }^{236}$, 3 vol.; Adriana ou Historia da Marqueza da Brianville, 3 vol; Alberto, ou o Desterro de Strathnaverm 3 vol., Os Dous Infelizes, ou Amélia Mansfield, e Ernesto Waldemar, 4 vol.; O Renegado, 2 vol.; A Estrangeira, 2 vol.; (...).

07

LEILÕES

Dodsworth faz leilão em sua casa n 38 rua da Alfandega, hoje 7 do corrente, de huma grande porção de livros nos idiomas Francez, e Inglez, entre os quaes seachão as obras seguintes: Fielding's Works, Robertson's history of América (...)

Na loja de papel, rua do Ouvidor $n$. 75, achão-se á venda os livros seguintes: Historia Galante do Joven Siciliano, 4 vol., Historia de Gil Braz de Santilhana, 4 vol. (...), Carolina de Lichtifield, ou o Triunfo da Virtude, 2 vol.; Viagens d'Altina, 4 vol.; Lances da Ventura, Accasos da Desgraça, e Heroísmo da Virtude, 6 vol.; O Desgraçado Napolitano, ou Vida de Monsieur Roselli, 1 vol., Adriana ou Historia da Marqueza de Brianville, 3 vol.; Alberto ou o Desterro de Strathnavern, 3 vol., O Renegado 2 vol.; A Extrangeira, 2 vol.

\section{Julho}

Na loja de papel da rua do Ouvidor $n$. 75 , ha para vender os livros seguintes: Historia do Joven Siciliano, 4 vol.; Historia de Gil Braz de Santilhana, 4 vol.; o Guarda Livros moderno, 3 vol.; Novellas Gallantes e Instrutivas, 2 vol.; Viagens d'Altina, 4 vol.; Adrianna, ou a Historia da Marqueza de Brianvelle, 3 vol.; Alberto, ou o Desterro de Strathuavern 3 vol.; a Estrangeira, 2 vol.; a Camponeza Exaltada, 4 vol.

\section{Agosto}

\footnotetext{
${ }^{236}$ HELME, Elizabeth. St. Clair of the Isles or the Outlaws of the Barra. A Scottish Tradition,
} 1803. 
Na loja de Papel, na rua do Ouvidor n. 75, vendem se os seguintes livros: Historia Galante do Jovem Siciliano, 4 vol. $7 \$ 000$ rs.; Historia de Gil Braz de Santilhana 4 vol. 8\$000; viagens d'Altina, 4 vol. 8\$000; Adrianna, ou Historia da Marqueza de Breanville, 3 vol. 6\$000; Alberto, ou o Desterro de Strathuavern, 3 vol. 6\$000; a Estrangeira, 2 vol. 4\$000; a Camponesa Exaltada, 4 vol. $8 \$ 000$.

\section{Outubro}

07 COMPRAS

Quem tiver $01^{\circ}$ e $2^{\circ}$ tomo, da obra de Robisson Crosué ${ }^{237}$; e os queira vender, annuncie por este Diario para ser procurado.

\section{Dezembro}

Na rua dos Ourives $n$. 86, ha para vender as obras seguintes em Portuguez: Ourik, $1 \$ 700$ rs.; Viagens de Guliver ${ }^{238}, 3$ v. 4\$, (...) as Duas de Desposadas, 4 vol. 6\$400; Clara d'Alba, $2 \$$; o dote de Suzaninha, 2 vol. 4\$, Caverna da Morte, $2 \$$; Vida de D. João Castro, 2\$880; Desgraçado Napolitano, $1 \$ 600 ;$ Irmã, 4 vol. $4 \$$; Escolha das Melhores Novellas, 8 vol. $12 \$ 800$ (...).

Na loja de livros de Albino Jordão, rua do Ouvidor n. 138, achão-se á venda as seguintes Novellas em Portuguez, e encadernadas: a llha Incognita 6 vol. com estampas $12 \$$ rs.; Leandro ou o pequeno casal 4 vol. $8 \$$ rs.; prazeres da imaginação que contém muitos contos \&c. 4 vol. $6 \$$ rs.; Filozofia por amor, ou cartas de dous amantdes 2 vol, em hum, 2\$rs.; Cartas de huma Peruviana ao seu amante 2 vol., em hum 1\$440; Aventuras aemorozas do Barão de Munkausen 1 vol. $2 \$$ rs..; Contos Filozoficos 1\$600.; Aventuras de Telemaco 2\$400; Marilia de Dirceo 2\$rs.; Escolha de Anedoctas 1\$rs.; Statira, e Zoroaste 2\$rs.; Ourika ou

${ }^{237}$ DEFOE, Daniel. The Life and Adventures of Robinson Crusoe, 1719.

${ }^{238}$ SWIFT, Jonathan. Gulliver's travels, 1726. 
Historia de huma preta 1\$440; Eduardo e Lucinda 1\$ br.; há mais os seguinte tambem encadernado, Noites de Young, 2 vol. $3 \$ 200$ (...).

\section{1}

\section{Janeiro}

Há para vender os livros seguintes em Portuguez, na rua dos Ourives n. 86: (...) Affonsa e Dalinda, $2 \$ 000$ rs.; Ouricka com gra.; 1\$6000; Duas Desposadas, 4 vol. 7\$000; Irma, 4 vol. 4\$800; a Caverna da Morte 2\$200; Clara d'Alba, $2 \$ 200$ (...) Joven Ciciliano, 4 vol. 7\$000; Saint-Claire das Ilhas ${ }^{239} 4$ vol. 4\$800; Joanninha 2 vol. 3\$00; Isidoro e Horaida, 4 vol. $7 \$ 000 ;(.$.

\section{Fevereiro}

01 Na loja de livros de Evaristo Ferreira da Veiga e Comp., rua dos Pescadoresn. 49, achão-se á venda as Novellas seguintes: Filosopho Ingles em 9 vol.; Mil e huma noites; Escolha das Melhores Novellas en 8 vol.; Deão de Killerine en 6 vol; Contos de Mongol, ou os Sonhos do Homem [..] em 5 vol.; Evaristo e Theodora; Gil Braz; Joven Siciliano (...); Leandro , ou o pequeno Casal; Piolho Viajante; Tom Jones $^{240}$; Vida de Mariana; Victor ou o menino da Selva; Vida de Robisson Crosoé $^{241}$ em 4 vol.; Anna Grenwil; Aventuras de Estevão Gonçalves; Mil e hum quarto d'Ora em 3 vol.; Carolina; Diabo Coxo; Emilia e Affonso; Emilia de Pourville, em 2 vol.; Caravançara; Noites Campestres; Paulo e Virginia (...) e

\footnotetext{
${ }^{239}$ HELME, Elizabeth. St. Clair of the Isles or the Outlaws of the Barra. A Scottish Tradition, 1803.

${ }^{240}$ FIELDING, Henry. Tom Jones, 1749.

${ }^{241}$ DEFOE, Daniel. The Life and Adventures of Robinson Crusoe, 1719.
} 
outros muitos Romances cuja lista só poderá ver na referida loja.

\section{Abril}

14 Na Praia dos Mineiros n. 49, vendem-se os seguintes livros encadernados: Filosofopho Inglez, 9 vol., Carlos e Maria 1 dito, Dois Robinsons 3 ditos, Pamella Andrews $^{242} 8$ ditos, Noites Clementinas 1 dito, Lances da Ventura 6 ditos, SaintClair das Ilhas 3 ditos, Gil-Braz 4 ditos, Victor, ou o Menino da Selva, Diabo Coxo 2 ditos, Laura de [Alfiso] 1 dito, Naufragio da Sepulveda 1 dito, Adelia de Sengange 1 dito - com brochura - Joanninha 2 ditos, Emilia e Affonso 2 ditos, Maria ou a filha da Desgraça 1 dito, As Desgraças de Idalina 1 dito, Luiza, ou a Cabana no Deserto ${ }^{243} 1$ dito, Azares da Fortuna 1 dito, Cartas de huma Peruviana 1 dito, Carlos e Maria 1 dito, Gonçalo de Cordova 2 ditos, Mulheres Celebres 2 ditos; todas estas obras são novas, e dão-se por commodo preço.

Na loja de livros de Albino Jordão, rua do Ouvidor, n.138, achão-se a venda as seguintes novellas em Portuguez, encadernadas, Barca da carreira dos Tolos por José Daniel 1 vol. $4 \$ 060$ rs. (...) Ilha Incognita 6 vol. com estampas, $8 \$ 000$. Leandro ou o pequeno casal, 4 vol. $6 \$ 000$, Carta de huma Peruviana, apaixonada ao seu amante 2 vol. em 1, 144., Mil e hum quarto de hora 3 vol. 4\$000, Chronica do Imperador Clarimundo 3 vol. 4\$000; Maria, ou a Menina Desgraçada 1 vol $1 \$ 600$, os Amantes Desterrados da Siberia 1 vol., $1 \$ 600$, Lances da Ventura, acasos das Desgraças, e Heroismo da Virtude, 6 vol. 9\$200, Aventuras de Robison Crusoé 2 vol. 3\$000; Aventuras de Carlos e Fany, 3 vol. 4\$800; Belisario de Marmontel, 1 vol. 1\$440; o Desgraçado Napolitano, 1 vol. 1\$600, Ourika ou Historia de huma preta em broxura 1\$000, o Amor Desgraçado ou Louzinski e Lodozaiska, 1 vol. 480; Eduardo e Lucinda, 1 vol. $1 \$ 000$.

\section{Maio}

Na loja de livros de Evaristo Ferreira da Veiga e Comp., rua dos Pescadores n, 49, achão-se a venda as seguintes obras em Hespanhol : (..) Vida de Napoleão por

\footnotetext{
${ }^{242}$ RICHARDSON, Samuel. Pamela. 1742.

${ }^{243}$ HELME, Elizabeth. Louisa , or the Cottage on the Moor, 1787.
} 
Sir Walter Scott, 18 vol. (...); e muitas outras obras no mesmo idioma, cuja lista se póde ver na referida loja.

Vende-se na Praia dos Mineiros n. 49, os livros seguintes: (...) Adelia de Senagne; Carlos e Fany, 3 vol.; Choupana India, 1 vol; Elizabeth, ou os Desterrados da Siberia, 1 vol.; Os Subterraneos, ou Mathilde, 2 vol.; Maria, ou a filha da desgraça; Luiza, ou a Cabana no deserto, 1 vol.; os Sibaritas, 2 vol.; Cecilia de Chautenay, 2 vol.; Prazeres da Imaginação, 4 vol

\section{Junho}

Na loja de livros de Evaristo Ferreira da Veiga e Comp., rua dos Pescadores n. 49, achão-se á venda as obras seguintes em Hespanhol: (...) Novella por Walter Scott, 1 vol.; (...)Eusebio por Montegen, 4 vol., Historia de Napoleão em 1812, 4 vol.; Dita do dito em 18?3, Ivanhoé, ou o Regresso da Palestina, por Sir Wlater Scott, 4 vol., Puritanos de Escocia, pelo dito, 4 vol., Quitin Daiward, pelo mesmo, 4 vol., Rob-Roy, pelo dito 4 vol.; (...) e muitas outras obras no mesmo idioma, cuja lista se póde vêr na referida loja.

\section{Julho}

06 Na Praia dos M??? ros n. 49, vendem-se os livros seguintes: Adelia de Senange, 1 vol. (...) Mil e hum quarto de hora 3 vol., Desgraças da Inconstância, 2 vol., (...) Viagens de Guliver, 3 vol., Camponesa exaltada, ou a virutude perseguida, 4 vol., Viagens de Antenor, 6 vol., Ilha incognita, 6 vol.;Maria ou a filha da Desgraça, 1 vol., Cartas de huma Peruviana, 1 vol.; Os Sibaritas, 2 vol., Prazeres da Imaginação , 4 vol.

\section{Agosto}

29 Na loja de livros de Albino Jordão, rua do Ouvidor n. 138, vende se as seguintes Novellas em Portuguez (encadernadas) Saint Clair das Ilhas, 4 vol., em 2, 5\$299, Statira e Soroaste (Novella Constitucional) 1\$600; Filosopha por amor, ou Cartas de Dois Amantes. 2 vol., Cartas de huma Peruviana ao seu amante, 2 vol. em 1, 1\$440; Memorias de João Brick, 1\$440, Eduardo e Lucinda, ou a portugueza Infiel, 1\$620; As ultimas despedidas do Marecha ${ }^{* * *}$ a seus filhos, 
1\$440, o Desgraçado Napolitano, 1\$660; a Aflição Conforada 1\$440; Novellas escolhidas, contando 15 em (2 vol.), 3\$200; Amigos Rivaes (...) Pedro, Novella Alemã, 180; Celestina, Novella Hespanholla 320 rs.

\section{Setembro}

Na loja de livros, rua da Alfandega, $n$. 23, vende-se os seguintes livros: (...)Water Scott 56 vol.; (...) e huma grande livraria escolhida, a qual se póde ver na referida loja.

Na loja de livros de Veiga e Comp., rua da Quitanda canta da de S. Pedro, tem para vender as seguintes Novellas em Portuguez: Mil e Hum Noites 8 vol., Novellas Orientaes, 7 vol., Ilha Incognita 6 vol., D. Quixote de la Mancha, 6 vol., Deão de Killerine, 6 vol (...) Robinson Crusoé, 4 vol.; Tom Jones ${ }^{244}, 4$ vol.; Victor ou o menino da Selva (...), Cecilia de Chatenai, 2 vol.; Carolina 2 vol., Diabo Coxo, 2 vol.; Emilia e Affonso, 2 vol., Historias Galantes, 2 vol.; Henriqueta de Ordeans, 2 vol., Joaninha, 2 vol., Novellas Galantes, 2 vol; o Renegado 2 vol., Solitario 2 vol., Votos Temerarios, 2 vol., Adelia Senange, 1 vol., Amigos Revaes, 1 vol, Hospital do Mundo, 1 vol.; Paulo e Virginia, 1 vol.; Carlos e Maria 1 vol., Luiza ou a Cabana do Deserto; Principe de Bretanha Zadigou o Destino vol. e hum grande numero de outras Novellas de que se póde ver a lista na referida loja.

\section{Novembro}

07 Na loja de livros de Veiga e Comp., rua da Quitanda canto da de S. pedro, ha para veneder as seguitnes Novelas: Mil e huma Noites, 8 vol., Novellas Orientaes, 7 vol., Ilha Incognita, 6 vol.; Mil e hum Serões, 5 vol.; Celestina, ou os Espozos sem o serem, 4 vol.; Gil-Braz de Santilhana com estampas 4 vol.; Isidoro e Horaida, 4 vol.; Leandro, ou o pequeno casal, 4 vol.; (...)Victor, ou o menino da Selva, 4 vol.; Carolina de Lichtfield, 2 vol.; Diabo Coxo, 2 vol.; Emilia de Tourville, 2 vol.; Heriqueta de Orleans, 2 vol.; Joaninha ou a engeitada generosa, 2 vol.; Amigos Rivaes, 1 vol.; Barco da Carreira dos Tolos, 21 vol.; Carta de huma Peruviana, 1 vol.; Choupana India, 1 vol.; Despedidas da Marechal, 1 vol.; Paulo e Virginia, 1 vol.; Lances da Ventura, 6 vol.; Orlando Amoroso, 3 vol.; Noites Romanas, 2 vol.;

${ }^{244}$ FIELDING, Henry. Tom Jones, 1749. 
O Salteador Saxonio, 2 vol.; Cartas Americanas , 1 vol.; Peregrinação de Fernão Mendes Pinto, 4 vol.; Saint Clair das Ilhas, 3 vol.; Amanda e Oscar, 6 vol.

Na Praia dos Mineiros, n. 49, vendem-se os seguintes livros encadernados: Mil e hum quarto de hora, 3 vol., Desgraças da Inconstancia, 2 vol.; Numa Pompilio, 2 vol.; Alexandre Magno, 2 vol.; Viagens de Guliver, 3 vol.; Camponesa exaltada, 4 vol.; Ilha Incognita, 6 vol.; Desgraçado Napolitano, 1 vol.; Robisson Crosué245, 2 vol.; Feliz Independente do Mundo, e da Fortuna, 3 vol. em brochura, Maria, 1 vol.; Cartas de huma Peruviana, 1 vol.; Sebaritas, 2 vol.; Prazeres da Imaginação, 4 vol.; Historia de Theodoro o Grande, 1 vol.

\section{Dezembro}

03

LIVROS A'VENDA

Na loja de livros de Albino Jordão, rua do Ouvidor, $n$. 137, vendem-se as seguintes Novellas em Portuguez: a Portugueza Infiel, 1\$600; a Afflição Confortada 1\$000; Paulo e Virginia 1\$440, Aventuras de Telemaco 3 vol, 5\$000 (...) Robisson Crusué, 2 vol. 3\$600; (...) Viagens de Guliver 3 vol. $5 \$ 200$ (...).

Na loja de livros de Albino Jordão, rua do Ouvidor, $n$. 137, vendem-se as seguintes Novellas em Portuguez: a Portugueza Infiel, 1\$600; a Afflição Confortada 1\$000; Paulo e Virginia 1\$440, Aventuras de Telemaco 3 vol, 5\$000 (...) Robisson Crusué, 2 vol. 3\$600; (...) Viagens de Guliver 3 vol. $5 \$ 200$ (...).

${ }^{245}$ DEFOE, Daniel. The Life and Adventures of Robinson Crusoe, 1719. 
Referências Bibliográficas

1. Fontes Manuscritas

ARQUIVO NACIONAL DO RIO DE JANEIRO (ANRJ)

Mesa do Desembargo do Paço - Caixas 168 - 171.

\section{Fontes Impressas}

Jornais

Gazeta do Rio de Janeiro. Rio de Janeiro, 1808 - 1821.

Diário do Rio de Janeiro. Rio de Janeiro, 1821 - 1844.

Registro de Estrangeiros 1823 - 1830. Produção do Ministério e Negócios Interiores - Arquivo Nacional. Rio de Janeiro: 1961.

Cartas de Luís Joaquim dos Santos Marrocos, escritas no Rio de Janeiro a sua família em Lisboa, de 1811 a 1821. Anais da Biblioteca Nacional do Rio de Janeiro. Rio de Janeiro: Imprensa Nacional, vol. LVI, 1939.

\section{Bibliografia}

ABREU, Márcia. (org.) Leitura, História e História da Leitura. Campinas, Mercado de Letras, 1999.

ABREU, Márcia. (org.). Trajetórias do Romance: circulação, leitura e escrita nos séculos XVIII e XIX. Campinas, SP: Mercado de Letras, 2008. 
ABREU, Márcia. Os Caminhos dos Livros. Campinas: Mercado de Letras, 2003.

ABREU, Márcia; SCHAPOCHNIK, Nelson (orgs.). Cultura letrada no Brasil: objetos e práticas. Campinas, SP: Mercado de Letras, Associação de Leitura do Brasil (ALB); São Paulo, SP: Fapesp, 2005.

ALGRANTI, L. M. "Política, religião e moralidade: a censura de livros no Brasil de D. João VI (1808 - 1821)" in Carneiro, Maria Luiza Tucci. (org.) Minorias Silenciadas: Historia da Censura no Brasil. São Paulo: EdUSP, s/d.

ALGRANTI, Leila Mezan. Censura e comércio de livros no período de permanência da corte portuguesa no Rio de Janeiro (1808 - 1821). in: Revista Portuguesa de História, t. XXXIII (1999), vol. 23, n. 1, 1999, pp.631-663.

ALGRANTI, Leila Mezan. Livros de devoção, atos de censura: Ensaios de História do Livro e da Leitura na América Portuguesa (1750 - 1821). São Paulo: Hucitec, 2004.

ARAUJO, Carlos Eduardo Moreira de. Cárceres Imperiais: A casa de Correção do Rio de Janeiro. Seus detentos e o sistema prisional no império, 1830 1861. Tese (Doutorado) - Instituto de Filosofia e Ciências Humanas, Universidade Estadual de Campinas, Campinas, 2009, p. 82.

ARMITAGE, João. História do Brasil: desde o período da chegada da família de Bragança, em 1808, até a abdicação de S. Pedro I, em 1831. Belo Horizonte: Itatiaia; São Paulo: EdUsp, 1915.

BEIER, José Rogério. Daniel Pedro Müller e a trajetória de seu Mappa Chorographico da Provincia de São Paulo: da encomenda à impressão e apresentação à Assembleia Legislativa da Província de São Paulo (18351842). Apresentação no IV Simpósio Iberoamericano de História da Cartografia, realizado na Biblioteca Nacional de Portugal de 11 a 14 de setembro de 2013.

BERMINGHAM. Ann. Consumption of Culture: 1600 - 1800. Image, Object, Text. New York: Routledge, 1997, p. 11.

BLANCHE, Henri Boullier de. Inventário Sumário dos documentos da Secretaria de Estado da Marinha. Rio de Janeiro: Ministério da Justiça e Negócios Interiores, Arquivo Nacional, 1930. 
BROCA, Brito. Românticos, pré-românticos, ultra-românticos: vida literária e romantismo brasileiro. São Paulo: Polis; Brasília: INL, 1979.

BRÜGGER, Silvia Maria Jardim. Minas patriarcal - Família e sociedade (São João Del Rei - Séculos XVIII e XIX). São Paulo, Annablume, 2007, p.314.

CANDIDO, Antônio. Formação da literatura brasileira. Belo Horizonte: Itatiaia, 1981.

CARDOSO, Teresa Maria Rolo Fachada Levy. A Gazeta do Rio de Janeiro: subsídios para a história da cidade (1808-1821). Dissertação de mestrado. Rio de Janeiro, Universidade Federal do Rio de Janeiro (UFRJ), 1988.

CARNEIRO, Maria Luiza Tucci. (org.) Minorias Silenciadas: História da Censura no Brasil. São Paulo: EdUSP, s/d.

CAVALLO, Guglielmo; CHARTIER, Roger. História da leitura no mundo ocidental. São Paulo: Ática, 2002.

CHARTIER, Roger. A ordem dos livros: leitores, autores e bibliotecas na Europa entre os séculos XIV e XVIII. Trad. Mary Del Priori. Brasília: Editora Universidade de Brasília, 1999.

CHARTIER, Roger. Cultura Escrita, Literatura e História: conversas de Roger Chartier com Carlos Aguirre Anaya, Jesús Anaya Rosique, Daniel Goldin e Antonio Saborit. Trad. Ernani Rosa. Porto Alegre: ARTMED Editora, 2001.

CHARTIER, Roger. Leituras e leitores na França no Antigo Regime. Trad. Álvaro Lorencini. São Paulo: Editora Unesp, 2004.

CHARTIER, Roger. Práticas da Leitura. Trad. Cristiane Nascimento. São Paulo: Estação Liberdade, 1998.

COSTA, Wilma Peres; OLIVEIRA, Cecília Helena de Salles (orgs.) De um império a outro: estudos sobre a formação do Brasil, séculos XVIII e XIX. São Paulo: Hucitec, 2007.

DARNTON, Robert. "What is the History of Books?" 1982 in http://dash.harvard.edu/handle/1/3403038. Ultimo acesso em Janeiro de 2014.

DIAS, Cleber Augusto Gonçalves. História do Lazer na Natureza do Rio de Janeiro. (2011) Tese de Doutorado apresentada à Pós-Graduação da Faculdade de Educação Física da Universidade Estadual de Campinas.

DIAS, Maria Odila Silva. A interiorização da metrópole e outros estudos. São Paulo: Alameda, 2005.

DINIZ, Sílvio Gabriel. Um livreiro em Vila Rica no meado do século XVII. In: Kriterion, 47/8, 1959, pp. 186-194.

EAGLETON, Terry. The English novel: An introduction. Oxford: Blackwell, 2005. 
ENDERS, Armelle. A História do Rio de Janeiro. Rio de Janeiro: Griphus, 2008.

ESTEVES, Mauro. LIVRO 18 (1841 - 1844) - Sinopse dos Inventários e Testamentos de Porto Alegre RS - 1776 - 1852. Disponível em http://pt.scribd.com/doc/45971157/17/LIVRO-18-1841-1844. Acessado em: 8 de maio de 2013.

FRANÇA, Jean Marcel Carvalho. Visões do Rio de Janeiro Colonial: Antologia de textos (1531 - 1800). Rio de Janeiro: EdUERJ, J. Olympio, 1999.

FREYRE, Gilberto. Ingleses no Brasil: Aspectos da influência britânica sobre a vida, a paisagem e a cultura do Brasil. Rio de Janeiro: Topbooks, 2000.

GERSON, Brasil. História das Ruas do Rio. Rio de Janeiro: Lacerda Ed., 2000.

GRAHAM, Maria. Correspondência entre Maria Graham e a Imperatriz Dona Leopoldina e cartas anexas. Trad. Américo Jacobina Lacombe. Belo Horizonte: Editora Itatiaia Itda., 1997.

GRAHAM, Maria. Diário de uma viagem ao Brasil. Trad. A.J.L. Belo Horizonte: Itatiaia; São Paulo: Editora da Universidade de São Paulo, 1990.

GUIMARÃES, C. G. "O "comércio de carne humana" no Rio de Janeiro: o negócio do tráfico negreiro e João Rodrigues Pereira de Almeida e da firma Joaquim Pereira de Almeida \& Co., 1808-1830 - primeiros esboços. " em África passado e presente: II Encontro de Estudos Africanos da UFF [recurso eletrônico] / org. Ribeiro, Alexandre; Gebara, Alexsander; Bittencourt, Marcelo Niterói: PGHISTÓRIA-UFF.2010. Disponível em http://www.historia.uff.br/stricto/files/public_ppgh/hol_2010_AfricaPassadoPrese nte.pdf Ultimo acesso em abril de 2012

HALLEWELL, Laurence. O Livro no Brasil: sua história. Trad.: Maria da Penah Villalobos, Lólio Lourenço de Oliveira e Geraldo Gerson de Souza. São Paulo: Editora da Universidade de São Paulo, 2005.

HOLANDA, Sérgio Buarque de Holanda. Raízes do Brasil. São Paulo: Companhia das Letras, 1995. 
http://www.historiaemreflexao.ufgd.edu.br/A18/D.\%20JOAO\%20VI\%20NO\%20 RIO\%20DE\%20JANEIRO\%20preparando\%20o\%20novo\%20cenario.pdf?PHP SESSID=4cce677f287b7e7bf2a50b81c45bcd01. Último acesso em dezembro de 2009.

IPANEMA, Cibelle. Na construção da história editorial do país: o versátil Silva Porto, mercador de livros, intelectual e editor. in: http://www.livroehistoriaeditorial.pro.br/ii_pdf/Cybelle_M_Ipanema.pdf Acesso: 11 de dezembro de 2009.

IPANEMA, Marcello \& Cybelle. Subsídios para a História das Livrarias in Revista do Livro, Rio de Janeiro, 1968, n. 32, ano XI, pp. 23 - 31.

JOBIM, José Luís. (org) A Biblioteca de Machado de Assis. Rio de Janeiro: Topbooks, 2001.

JOINVILLE, François Ferdinand Philippe Louis Marie d'Orleans. Diário de um príncipe no Rio de Janeiro. Trad. Marisa Murray. Rio de Janeiro: José Olympio, 2006.

JURATIC, Sabine. Da prosopografia dos livreiros ao estudo das redes do livro. Balanço e perspectivas da pesquisa. Livro. Revista do Núcleo de Estudos do Livro e da Edição. N. 1, maio 2011. São Paulo: USP/Ateliê Editorial, LAHUERTA, Flora Medeiros. Viajantes e a construção de uma idéia de Brasil no caso da colonização. in: Scripta Nova - Revista Eletrónica de Geografía y Ciencias Sociales, Universidad de Barcelona, Vol. X, núm. 218 (64), agosto de 2006.

LAJOLO, M. e ZILBERMAN, R. A Formação da Leitura no Brasil. São Paulo: Ática, 1996.

LAJOLO, Marisa.; Zilberman, Regina. A leitura rarefeita: leitura e livro no Brasil. São Paulo: Ática, 2002.

LAJOLO, Marisa; ZILBERMAN, Regina. A Formação da Leitura no Brasil. São Paulo, Ática, 1996.

LESSA, C. R. "As bibliotecas brasileiras dos tempos coloniais: apontamentos para um estudo histórico" in: Revista do Instituto Histórico e Geográfico Brasileiro, vol. 191, 1946, p. 277. 
LIMA, Manuel de Oliveira. D. João VI no Brasil: 1808-1821, 2 vols. Rio de Janeiro: Topbooks, 2006.

LOPEZ, Emílio Carlos Rodriguez. Festas públicas, memória e representação: Um estudo sobre manifestações políticas na Corte do Rio de Janeiro - 1808-1822. São Paulo: Humanitas, 2002.

LUCCOCK, John. Notas sobre o Rio de Janeiro e partes meridionais do Brasil. Belo Horizonte: Itatiaia; São Paulo: EdUsp, 1975.

LUKÁCS, Georg. Teoria do Romance. São Paulo: Editora 34, 2000.

LYRA, Maria de Lourdes Viana. A utopia do poderoso império: Portugal e Brasil: bastidores da política 1798 - 1822. Rio de Janeiro: Sette Letras, 1994.

MACEDO, Joaquim Manuel de. Memórias da Rua do Ouvidor. Brasília: Editora Universidade de Brasília, 1988.

MACHADO, Ubiratan. História das Livrarias Cariocas. São Paulo: EdUSP, 2012.

MACHADO, Ubiratan. A Etiqueta de livros no Brasil: subsídios para uma história das livrarias. São Paulo: Editora da Universidade de São Paulo, Oficina do Livro Rubens Borba de Moraes, Imprensa Oficial do Estado de São Paulo, 2003.

MACHADO, Ubiratan. A vida literária no Brasil durante o romantismo. Rio de Janeiro: EdUERJ, 2001.

MALERBA, Jurandir: A corte no exílio: civilização e poder no Brasil às vésperas da independência - 1808-1821. São Paulo: Companhia das Letras, 2000.

MANCHESTER, Alan K. British Preeminence in Brazil: its rise and decline. New York: Octagon Books, 1972.

MARCILIO, Maria Luiza. Caiçara: terra e população, Estudos de demografia histórica e da história social de Ubatuba, São Paulo: Edições Paulinas/CEDHAL, 1986. p. 70.

MARTINHO, Lenira Menezes; GORENSTEIN, Riva. Negociantes e caixeiros na sociedada da independência. Prefeitura da Cidade do Rio de Janeiro, Secretaria Municipal de Cultura, Turismo e Esportes. Divisão de Editoração. S.d. 
MARTINS, Wilson. A palavra escrita: História do livro, da imprensa e da biblioteca. São Paulo: Ática, 2002.

MAXWELL, Kenneth. Chocolate, piratas e outros malandros: ensaios tropicais. Rio de Janeiro: Paz e Terra, 1999.

MAY, William Henry. Diário de uma viagem da baía de Botafogo à cidade de São Paulo (1810). Trad. Jean Marcel Carvalho França. Rio de Janeiro: José Olympio, 2006.

MELLO, Evaldo Cabral de. Um imenso Portugal: História e historiografia. São Paulo: Editora 34, 2002.

MEYER, Marlyse. Machado de Assis lê Saint Clair das llhas in Literatura e Sociedade, São Paulo: Universidade de São Paulo, 1998, n. 3, pp. 17-33.

MEYER, Marlyse. O que é, ou quem foi Sinclair das llhas? in Revista do Instituto de Estudos Brasileiros. São Paulo: Universidade de São Paulo, 1973, n. 14 , pp. $37-63$.

MONTEIRO, Maurício. A Construção do Gosto: Música e sociedade na Corte do Rio de Janeiro - 1808 - 1821. São Paulo: Ateliê Editorial, 2008, pág. 112.

MORAES, Rubens Borba de. Livros e bibliotecas no Brasil colonial. Rio de Janeiro: LTC, 1979.

MOREL, Marco. Transformações dos Espaços Públicos: Imprensa, Atores Políticos e Sociabilidades na Cidade Imperial (1820 - 1840). São Paulo: Hucitec, 2005.

MORETTI, Franco. Atlas of the European Novel 1800-1900. London: Verso, 1999. Ed. bras.: Atlas do Romance Europeu 1800-1900. São Paulo: Boitempo, 2004.

MOTA, Carlos G. 1822: Dimensões. São Paulo: Editora Perspectiva, 1972.

NEVES, L. M. B. Livreiros franceses no Rio de Janeiro: 1799 - 1824. In http://www.portcom.intercom.org.br/pdfs/bb3aea30006796253008218e5bdda0c 1.pdf. Ultimo acesso: Janeiro de 2014.

NEVES, Lúcia Maria Bastos P. "Antídotos contra obras ímpias e sediciosas: censura e repressão no Brasil de 1808 a 1824" in: ABREU, M. Leitura, história e história da leitura. Campinas: Mercado de Letras, 2002, pp. 377-394. 
NEVES, Lucia Maria Bastos Pereira das. As representações napoleônicas em Portugal: Imaginário e Política (1808-1810). Tese apresentada ao Instituto de Filosofia e Ciências Humanas da Universidade do Estado do Rio de Janeiro, como requisito ao Concurso Público para Professor Titular na área de História moderna. Rio de Janeiro, 2002.

NEVES, Lucia Maria Bastos Pereira das. Comércio de livros e censura de idéias: A actividade dos livreiros franceses no Brasil e a vigilância da Mesa do $\begin{array}{lllll}\text { Desembargo do Paço } & \text { 1795 }\end{array}$ in: Ler História, n.23, Lisboa, 1992, pp 61-78.

NEVES, Lucia Maria Bastos Pereira das. Produção, distribuição e consumo de livros no Brasil colonial. In: Revista Colóquio/ Letras. Cópia digital N .50 , julho de 1979.

NEVES, Lucia Maria Bastos Pereira das. Trajetórias de Livreiros no Rio de Janeiro: Uma Revisão Historiográfica - João Roberto Bourgeois e Paulo Martin. In: ww.rj.anpuh.org/Anais/2002/Mesas/Neves Acesso: 10 de dezembro de 2008.

NEVES, Lucia Maria Bastos Pereira das; FERREIRA, Tania Maria Bessone da Cruz. Livreiros no Rio de Janeiro: intermediários culturais entre Brasil e Portugal ao longo do oitocentos. In:

http://www.realgabinete.com.br/coloquio/3_coloquio_outubro/paginas/16.htm Acesso: 10 de dezembro de 2009

NOVAIS, Fernando. Portugal e Brasil na crise do Antigo Sistema Colonial, São Paulo: Hucitec, 1979.

NOVAIS, Fernando; MOTA, Carlos Guilherme. A independência política do Brasil. São Paulo: Hucitec, 1996.

OLIVEIRA, Anelise Martinelli Borges. D. João VI no Rio de Janeiro: preparando um novo cenário. In: História em reflexão: revista eletrônica de História. http://www.historiaemreflexao.ufgd.edu.br/_Acesso: 20 de dezembro de 2009. OLIVEIRA. Anelise Martinelli Borges. "D. João VI no Rio de Janeiro: preparando um novo cenário". In: História em reflexão: revista eletrônica de História: 
RIOS, Adolfo Morales de los. O Rio de Janeiro Imperial. Rio de Janeiro: Topbooks, 2000.

RIZZINI, Carlos. O Livro, o Jornal e a Tipografia no Brasil (1500 - 1822). São Paulo: Imprensa Oficial do Estado, 1988.

RODRIGUES, A. A. Gonçalves. A tradução em Portugal vol. I 1495 - 1834. Lisboa: Imprensa Nacional casa da Moeda. s/d.

SANT, Ann Jessie Van. Eighteen-Century Sensibility and The Novel: The Senses in Social Context, Cambridge: Cambridge University Press, 1993.

SCHAPOCHNIK, Nelson. Contextos de leitura no Rio de Janeiro do século XIX: Salões, gabinetes literários e bibliotecas. In: BRESCIANI, Stella. (Org.). Imagens da cidade, séculos XIX e XX. São Paulo: Marco Zero, 1994, pp. 147162.

SCHAPOCHNIK, Nelson. Jardins das delícias: gabinetes literários, bibliotecas e figurações da leitura na Corte Imperial. São Paulo, 1999. Tese (Doutorado) - Departamento de História da FFLCH, Universidade de São Paulo.

SCHAPOCHNIK, Nelson. Um palácio de livros nos trópicos: metáfora, projetos e concretizações. Projeto História n²6. São Paulo: Educ, 2003, pp.93-115. SCHRÖDER, F., DREHER, M.N., A imigração alemã para o sul do Brasil até 1859. São Leopolso: EDIPUCRS, 2003, p. 33.

SCHULTZ, Kirsten. Versalhes tropical: império, monarquia e a corte real portuguesa no Rio de Janeiro, 1808 - 1821. Rio de Janeiro: Editora Civilização Brasileira, 2008.

SCHWARCZ, Lilia Moritz. "D. João VI e os livros no Brasil: o caso da Real Biblioteca" in: http://www.realgabinete.com.br/coloquio/3_coloquio_outubro/paginas/14.htm\#_f tnref29 Acesso: 10 de dezembro de 2009

SCHWARCZ, Lilian Moritz. A longa viagem da biblioteca dos reis: do terremoto de Lisboa à independência do Brasil. São Paulo: Companhia das Letras, 2002. 
SEMERARO, Cláudia Marina (org.) História da Tipografia no Brasil. São Paulo, SP: Museu de Arte de São Paulo/ Secretaria de Cultura, Ciências e Tecnologia do Governo do Estado de São Paulo, 1979.

SILVA, Ana Rosa Cloclet da. Inventando a Nação: Intelectuais ilustrados e estadistas luso-brasileiros na crise do antigo regime português. São Paulo: Editora Hucitec, 2006.

SILVA, C. B. "Uma perspectiva atlântica: a circulação de mercadorias no Rio de Janeiro após a transferência da Corte portuguesa para o Brasil (1808-1821)." Revista Navigator - Subsídios para a História Marítima do Brasil, volume 8, N. 16, 2012.p. 28

SILVA, Maria Beatriz Nizza da. A Gazeta do Rio de Janeiro (1808-1822) Cultura e Sociedade. Rio de Janeiro: EdUERJ, 2007.

SILVA, Maria Beatriz Nizza da. Cultura e sociedade no Rio de Janeiro (1808-1821). 2a. edição, São Paulo: Companhia Editora Nacional, 1978.

SILVA, Maria Beatriz Nizza da. Livro e sociedade no Rio de Janeiro (1808 1821) - Comunicação apresentada na $3^{\text {a }}$ Sessão de Estudos no dia 7 de julho de 1972.

SILVA, Maria Beatriz Nizza da. Luzes nas bibliotecas de Francisco Agostinho Gomes e Daniel Pedro Muller, dois intelectuais lusos-brasileiros. In: http://www.instituto-camoes.pt/cvc/eaar/coloquio/comunicacoes Acesso: 20 de dezembro de 2009.

SLEMIAN, Andréa e João Paulo Garrido Pimenta - 0 ,nascimento político" do Brasil: as origens do estado e da nação (1808-1825). Rio de Janeiro: DP\&A, 2003.

SLEMIAN, Andréa. Vida política em tempo de crise: Rio de Janeiro (18081824). São Paulo: Hucitec, 2006.

SODRÉ, Nelson Werneck. História da Imprensa no Brasil. Rio de Janeiro: Mauad, 1999.

SOUZA, lara Lis Carvalho. Pátria Coroada: o Brasil como corpo político autônomo - 1780 - 1831. São Paulo: Unesp, 1999. 
SOUZA, Laura de Mello e. O sol e a sombra: política e administração na América portuguesa do século XVIII. São Paulo: Companhia das Letras, 2006.

SOUZA, Simone Cristina Mendonça. Primeiras impressões: romances publicados pela Impressão Régia do Rio de Janeiro (1808-1822). Tese de doutorado, Instituto de Estudos da Linguagem, da Universidade Estadual de Campinas, 2007.

SPIX, Johann Baptist Von. Viagem pelo Brasil: 1817-1820. Trad. Lúcia Furquim Lahmeyer. Belo Horizonte: Ed. Itatiaia; São Paulo: Ed. da Universidade de São Paulo, 1981.vol.1.

SZMRECSÁNYI, Tamas (org.) História Econômica do Período Colonial. São Paulo: Hucitec, 2002.

TADIÉ, Alexis. From the Ear to the Eye: Perceptions of Language in the Fictions of Laurence Sterne. in: SYRONTINSKI, Michael e MACLACHLAN, Ian. Sensual Reading: New Approaches to Reading in its Relations to the Senses. Cranbury: Associated University Press, 2001, pp. 106 - 123.

TOLEDO, Benedito Lima de. São Paulo: 3 cidades em um século. São Paulo: Livraria duas cidades, 1981.

TOUSSAINt-Samsom, Adèle. Uma parisiense no Brasil. Trad. Maria Lucia Machado. Rio de Janeiro: Editora Capivara, 2003.

TRAMONTINI, Marcos Justo. A colônia de São Leopoldo: A organização social dos imigrantes na fase pioneira (1824-1850) - Tese de Doutorado - UNISINOS Programa de Pós-Graduação em História. Disponível em http://www.siters.com.br/Obra/Capitulo.asp?IdCapitulo=3\&NomeSecao=Historia Acessado em: 10 de maio de 2013.

TRIGUEIRO, António Minguel.. As ordens militares portuguesas no império do

Brasil

http://www.conteudos.easysite.com.pt/files/48/ficheiros/emblematica/AsOrdens _MilitaresPortuguesasnolmperiodoBrasil_revistaMoeda.pdf.pdf Acesso em: 7 de fevereiro de 2013.

VASCONCELOS, Sandra Guardini Teixeira. Dez lições sobre o romance inglês do século XVIII. São Paulo: Boitempo, 2002. 
VASCONCELOS, Sandra Guardini Teixeira. Formação do Romance Brasileiro: 1808 - 1860 (Vertentes Inglesas) disponível no site: www.unicamp.br/iel/memoria/Ensaios Acesso: 02 de dezembro de 2009.

VILLALTA, Luís Carlos. "Reformismo ilustrado, Censura e Práticas de Leitura: usos do livro na América Portuguesa." Tese de Doutoramento. Departamento de História da Faculdade de Filosofia, Letras e Ciências Humanas da Universidade de São Paulo, 1999, p. 16.

VILLALTA, Luís Carlos. 1789-1808: O império luso-brasileiro e os Brasis. São Paulo: Companhia das Letras, 2000.

VILLALTA, Luís Carlos. A história do livro e da leitura no Brasil colonial: balanço historiográfico e proposição de uma pesquisa sobre o Romance. Disponível no site: http://www.caminhosdoromance.iel.unicamp.br/ VILLALTA, Luís Carlos. Reformismo ilustrado, Censura e Práticas de Leitura: usos do livro na América Portuguesa. Tese de Doutoramento apresentada ao Departamento de História da Faculdade de Filosofia, Letras e Ciências Humanas da Universidade de São Paulo, 1999.

WATT, lan. The Rise of the Novel. Studies in Defoe, Richardson and Fielding. Penguin, 1968. Trad. bras.: A Ascensão do Romance. São Paulo: Companhia das Letras, 1996.

WILCKEN, Patrick. Império à deriva: a Corte portuguesa no Rio de Janeiro 1808 - 1821. trad. Vera Ribeiro. Rio de Janeiro: Objetiva, 2005.p. 198.

WILCKEN, Patrick: Império à deriva: a Corte portuguesa no Rio de Janeiro, 1808-1821. Rio de Janeiro: Objetiva, 2005. 